\title{
Design and Evaluation of New Quinazolin-4(3H)-one Derived PqsR Antagonists as Quorum Sensing Quenchers in Pseudomonas aeruginosa
}

Fadi Soukarieh, Alaa Mashabi, William Richardson, Eduard Vico Oton, Manuel Romero, Shaun N. Roberston, Scott Grossman, Tomas Sou, Ruiling Liu, Nigel Halliday, Irena Kukavica-Ibrulj, Roger C. Levesque, Christel A. S. Bergstrom, Barrie Kellam, Jonas Emsley, Stephan Heeb, Paul Williams, Michael J. Stocks, * and Miguel Cámara*

Cite This: https://doi.org/10.1021/acsinfecdis.1c00175

Read Online

ABSTRACT: $P$. aeruginosa (PA) continues to pose a threat to global public health due to its high levels of antimicrobial resistance (AMR). The ongoing AMR crisis has led to an alarming shortage of effective treatments for resistant microbes, and hence there is a pressing demand for the development of novel antimicrobial interventions. The potential use of antivirulence therapeutics to tackle bacterial infections has attracted considerable attention over the past decades as they hamper the pathogenicity of target microbes with reduced selective pressure, minimizing the

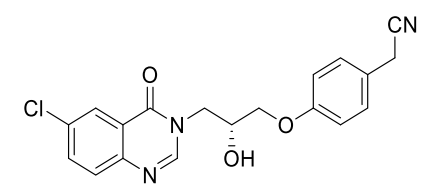

PqsR antagonist 61 $\kappa_{\mathrm{d}}=10.2 \pm 4.9 \mathrm{nM}$

PAO1-L mCTX:: $P_{p q s A}-l$ IUX IC $C_{50}=1.1 \pm 0.4 \mu \mathrm{M}$

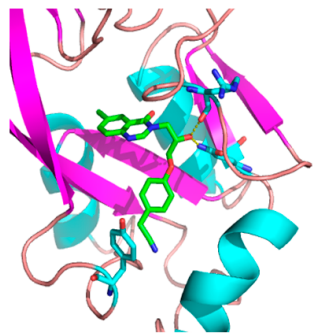
emergence of resistance. One such approach is to interfere with the PA pqs quorum sensing system which upon the interaction of PqsR, a Lys-R type transcriptional regulator, with its cognate signal molecules 4-hydroxy-2-heptylquinoline (HHQ) and 2-heptyl-3-hydroxy-4-quinolone (PQS), governs multiple virulence traits and host-microbe interactions. In this study, we report the hit identification and optimization of PqsR antagonists using virtual screening coupled with whole cell assay validation. The optimized hit compound 61 ((R)-2-(4-(3-(6-chloro-4-oxoquinazolin-3(4H)-yl)-2hydroxypropoxy)phenyl)acetonitrile) was found to inhibit the expression of the PA $\mathrm{P}_{p q s A}$ promoter controlled by PqsR with an $\mathrm{IC}_{50}$ of $1 \mu \mathrm{M}$. Using isothermal titration calorimetry, a $K_{\mathrm{d}}$ of $10 \mathrm{nM}$ for the PqsR ligand binding domain $\left(\mathrm{PqsR}^{\mathrm{LBD}}\right)$ was determined for 61. Furthermore, the crystal structure of 61 with $\mathrm{PqsR}^{\mathrm{LBD}}$ was attained with a resolution of $2.65 \AA$. Compound 61 significantly reduced levels of pyocyanin, PQS, and HHQ in PAO1-L, PA14 lab strains and PAK6085 clinical isolate. Furthermore, this compound potentiated the effect of ciprofloxacin in early stages of biofilm treatment and in Galleria mellonella infected with PA. Altogether, this data shows $\mathbf{6 1}$ as a potent PqsR inhibitor with potential for hit to lead optimization toward the identification of a PA QS inhibitor which can be advanced into preclinical development.

KEYWORDS: Pseudomonas aeruginosa, PqsR, Pseudomonas quinolone signal (PQS), biofilms, quorum sensing inhibition

$\mathrm{T}$ he rising, wide spread of antimicrobial and multidrugresistant bacterial strains at an unprecedented rate places a major burden on global public health predominantly with regard to the shortage of effective therapeutic options. ${ }^{1}$ Alarmingly, within the antibacterial pipelines currently under clinical development, there is no novel antibacterial class that could actively treat any of the WHO top priority pathogens also known as ESKAPE (Enterococcus faecium, Staphylococcus aureus, Klebsiella pneumoniae, Acinetobacter baumannii, Pseudomonas aeruginosa, and Enterobacter spp). ${ }^{2,3}$ P. aeruginosa (PA) is a Gram-negative opportunistic bacterium and a common cause for nosocomial infections particularly in cystic fibrosis and immunocompromised patients. ${ }^{4}$ Consequently, there is an urgent need for the discovery of novel approaches to combat bacterial infections with mechanisms of action that do not impose strong selective pressure on bacteria. ${ }^{5}$ In fact, over the past decades, the focus of the preclinical antibacterial projects was shifted toward new targets, mostly in Gram-negative pathogens, as in the case of antivirulence approaches, adjuvant therapies, and antibiotic potentiators. ${ }^{6}$ One of the extensively investigated approaches to target virulence is the development of drugs which can interfere with bacterial quorum sensing systems (QSSs). These are cell-to-cell communication mechanisms used by many bacterial pathogens to control the

Received: March 31, 2021 

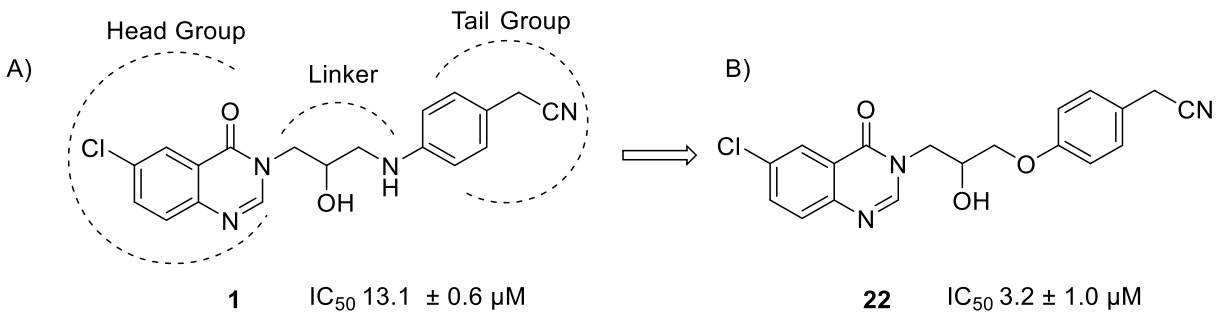

Figure 1. (A) Chemical structure of $p q$ s hit with site of modifications and (B) improved hit molecule 22, with improved activity.

Scheme 1. Synthetic Route for 22 and its Analogues 23-41 ${ }^{a}$<smiles>[R]c1nc2cc[R1]cc2c(=O)[nH]1</smiles>

$2 \mathrm{R}^{1}=6-\mathrm{Cl} \quad \mathrm{R}^{2}=\mathrm{H}$;

$3 \mathrm{R}^{1}=7-\mathrm{Cl} \quad \mathrm{R}^{2}=\mathrm{H}$

$4 \mathrm{R}^{1}=6,7-\mathrm{Cl} \mathrm{R}^{2}=\mathrm{H}$;

$5 \mathrm{R}^{1}=6,8-\mathrm{Cl} \mathrm{R}^{2}=\mathrm{H}$

$6 \mathrm{R}^{1}=5-\mathrm{Cl} \quad \mathrm{R}^{2}=\mathrm{H}$;

$7 \mathrm{R}^{1}=8-\mathrm{Cl} \quad \mathrm{R}^{2}=\mathrm{H}$

$8 \mathrm{R}^{1}=6-\mathrm{NO}_{2} \mathrm{R}^{2}=\mathrm{H}$

$9 \mathrm{R}^{1}=7-\mathrm{NO}_{2} \mathrm{R}^{2}=\mathrm{H}$;

$10 \mathrm{R}^{1}=6-\mathrm{CF}_{3} \mathrm{R}^{2}=\mathrm{H}$

$11 R^{1}=6-\mathrm{Cl} \quad R^{2}=\mathrm{Me}$

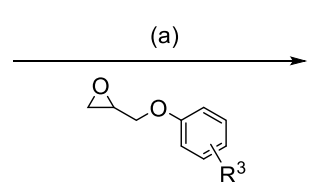

$12 \mathrm{R}^{3}=p-\mathrm{CH}_{2} \mathrm{CN}$

$13 \mathrm{R}^{3}=m-\mathrm{CH}_{2} \mathrm{CN}$

$14 \mathrm{R}^{3}=p-\mathrm{CN}$

$15 \mathrm{R}^{3}=m-\mathrm{CN}$

$16 \mathrm{R}^{3}=p-\mathrm{CH}_{2} \mathrm{CH}_{2} \mathrm{CN}$

$17 R^{3}=4$-(cyclopropane-1-

carbonitrile)

$18 \mathrm{R}^{3}=m-\mathrm{F}, p-\mathrm{CH}_{2} \mathrm{CN}$

$19 \mathrm{R}^{3}=o-\mathrm{F}, p-\mathrm{CH}_{2} \mathrm{CN}$

$20 \mathrm{R}^{3}=p-\mathrm{OCH}_{2} \mathrm{CN}$

$21 \mathrm{R}^{3}=p$-phenoxy<smiles></smiles>

$\begin{array}{ll}22 \mathrm{R}^{1}=6-\mathrm{Cl}, & \mathrm{R}^{2}=\mathrm{H}, \mathrm{R}^{3}=p-\mathrm{CH}_{2} \mathrm{CN} \\ 23 \mathrm{R}^{1}=7-\mathrm{Cl}, & \mathrm{R}^{2}=\mathrm{H}, \mathrm{R}^{3}=p-\mathrm{CH}_{2} \mathrm{CN} \\ 24 \mathrm{R}^{1}=6,7-\mathrm{Cl}, \mathrm{R}^{2}=\mathrm{H}, \mathrm{R}^{3}=p-\mathrm{CH}_{2} \mathrm{CN} & \mathrm{R}^{1} \mathrm{R}^{1}=6,8-\mathrm{Cl}, \mathrm{R}^{2}=\mathrm{H}, \mathrm{R}^{3}=p-\mathrm{CH}_{2} \mathrm{CN} \\ 26 \mathrm{R}^{1}=5-\mathrm{Cl}, & \mathrm{R}^{2}=\mathrm{H}, \mathrm{R}^{3}=p-\mathrm{CH}_{2} \mathrm{CN} \\ 27 \mathrm{R}^{1}=8-\mathrm{Cl}, & \mathrm{R}^{2}=\mathrm{H}, \mathrm{R}^{3}=p-\mathrm{CH}_{2} \mathrm{CN} \\ 28 \mathrm{R}^{1}=6-\mathrm{Br}, & \mathrm{R}^{2}=\mathrm{H}, \mathrm{R}^{3}=p-\mathrm{CH}_{2} \mathrm{CN} \\ 29 \mathrm{R}^{1}=6-\mathrm{NO}_{2}, & \mathrm{R}^{2}=\mathrm{H}, \mathrm{R}^{3}=p-\mathrm{CH}_{2} \mathrm{CN} \\ 30 \mathrm{R}^{1}=7-\mathrm{NO}_{2}, & \mathrm{R}^{2}=\mathrm{H}, \mathrm{R}^{3}=p-\mathrm{CH}_{2} \mathrm{CN} \\ 31 \mathrm{R}^{1}=6-\mathrm{CF}_{3}, & \mathrm{R}^{2}=\mathrm{H}, \mathrm{R}^{3}=p-\mathrm{CH}_{2} \mathrm{CN}\end{array}$

$32 \mathrm{R}^{1}=6-\mathrm{Cl}, \mathrm{R}^{2}=\mathrm{Me}, \mathrm{R}^{3}=p-\mathrm{CH}_{2} \mathrm{CN}$

$33 \mathrm{R}^{1}=6-\mathrm{Cl}, \mathrm{R}^{2}=\mathrm{H}, \mathrm{R}^{3}=m-\mathrm{CH}_{2} \mathrm{CN}$

$34 \mathrm{R}^{1}=6-\mathrm{Cl}, \mathrm{R}^{2}=\mathrm{H}, \mathrm{R}^{3}=p-\mathrm{CN}$

$35 \mathrm{R}^{1}=6-\mathrm{Cl}, \mathrm{R}^{2}=\mathrm{H}, \mathrm{R}^{3}=m-\mathrm{CN}$

$36 \mathrm{R}^{1}=6-\mathrm{Cl}, \mathrm{R}^{2}=\mathrm{H}, \mathrm{R}^{3}=p-\mathrm{CH}_{2} \mathrm{CH}_{2} \mathrm{CN}$

$37 \mathrm{R}^{1}=6-\mathrm{Cl}, \mathrm{R}^{2}=\mathrm{H}, \mathrm{R}^{3}=p$-cyPr-CN

$38 \mathrm{R}^{1}=6-\mathrm{Cl}, \mathrm{R}^{2}=\mathrm{H}, \mathrm{R}^{3}=m-\mathrm{F}, p-\mathrm{CH}_{2} \mathrm{CN}$

$39 \mathrm{R}^{1}=6-\mathrm{Cl}, \mathrm{R}^{2}=\mathrm{H}, \mathrm{R}^{3}=o-\mathrm{F}, p-\mathrm{CH}_{2} \mathrm{CN}$

$40 \mathrm{R}^{1}=6-\mathrm{Cl}, \mathrm{R}^{2}=\mathrm{H}, \mathrm{R}^{3}=p-\mathrm{OCH}_{2} \mathrm{CN}$

$41 \mathrm{R}^{1}=6-\mathrm{Cl}, \mathrm{R}^{2}=\mathrm{H}, \mathrm{R}^{3}=m-\mathrm{F}, p-$ Phenoxy

${ }^{a}$ Reagents and conditions: (a) $\mathrm{Cs}_{2} \mathrm{CO}_{3}$, TBAI, $\mathrm{CH}_{3} \mathrm{CN}$, reflux, yields $21-80 \%$.

disease process. $^{7,8}$ PA possesses three types of QSSs that employ various diffusible chemical signals called quorum sensing signaling molecules (QSSMs) or autoinducers (AIs). The las and $r h l$ systems use $N$-acylhomoserine lactone derived signals while the $p q s$ system relies on alkyl quinolone (AQ) derived molecules. ${ }^{9}$ Using these systems, PA can coordinate the production of virulence determinants in a coordinated population-dependent manner in response to external stimuli or threats. ${ }^{10,11}$ While the las and $r h l$ systems have been studied extensively, the pqs system has been shown in recent years to play a substantial role in the virulence of $\mathrm{PA}^{7,12}$ The biosynthesis of the AQ signals 4-hydroxy-2-heptylquinoline (HHQ) and 2-heptyl-3-hydroxy-4-quinolone (PQS) is initiated from anthranilate through a sequence of enzymes (PqsA, PqsBC, PqsD, PqsH) encoded by pqsABCDEphnAB operon and the $p q s H$ gene. ${ }^{13,14}$ The resulting AQs then interact with the C-terminal ligand binding domain of the LysR type regulator PqsR (also known as MvfR) resulting in a conformational change leading to the activation of the $p q s$ operon, likely by binding to the $p q s A$ promoter $\left(\mathrm{P}_{p q s A}\right){ }^{13}$ To date, there have been several attempts to pharmacologically inhibit the $p q s$ system by either interfering with the biosynthesis of AQs targeting the biosynthetic enzymes (such as $\mathrm{PqsD}^{15}$ and $\mathrm{PqsA}^{16}$ ) or preventing the signal reception (through antagonists of PqsR). ${ }^{17}$ Several chemical series have been described as $\mathrm{PqsR} / p q s$ inhibitors including quinazolinone, quinolinone, thioacetamide, and hydroxybenzamide derived molecules, but none have yet been taken forward to clinical trials. ${ }^{7,18,19}$ In this study, we report a new series of quinazolinone derived pqs inhibitors with low micromolar potency in PA PAO1-L. Compound 61, one of the most potent inhibitors in this series, was evaluated using PA phenotypic analysis including pyocyanin and determination of AQ signal levels in various clinical and lab strains. The study also investigated the effect of $\mathbf{6 1}$ on PA biofilms, as a sole treatment or in combination with ciprofloxacin. Moreover, the cocrystal structure of two inhibitors $(61,40)$ with the PqsR ligand binding domain was obtained revealing the main interactions governing binding. To conclude this study, 61 was evaluated in a G. mellonella PA infection model alone and in conjunction with ciprofloxacin.

\section{RESULTS}

Identification of PqsR Hits through "in silico" Docking and Bioreporter Assays. A virtual screening of an in-house drug-like compound library composed of 85061 curated molecules was performed using the PqsR ligand binding domain (PDB 4JVI) employing the Schrödinger Suite for molecular docking. ${ }^{20,21}$ The 583 top scored compounds were selected after introduction of a Glide docking score threshold of -9.0. The selected compounds were then validated for their ability to inhibit the pqs QS system at a concentration of $10 \mu \mathrm{M}$ using the bioluminescence-based bioreporter strain PAO1-L harboring the chromosomal transcriptional fusion mCTX:: $\mathrm{P}_{p q s}-l u x$. For a molecule to score as active, a reduction of at least $50 \%$ of bioluminescence had to be achieved without affecting bacterial growth. This process led to the discovery of multiple hits, ${ }^{18,19}$ among them was 2-(4-((3-(6-chloro-4-oxoquinazolin-3(4H)-yl)-2hydroxypropyl)amino)phenyl)acetonitrile 1 with an $\mathrm{IC}_{50}$ of $13.1 \pm 0.6 \mu \mathrm{M}$ (Figure 1).

Synthetic Chemistry Exploration for the StructureActivity Relationship Study. To investigate the structureactivity relationship (SAR) of $\mathbf{1}$, our synthetic strategy focused on three sites of modification: the quinazoline headgroup, the 
Scheme 2. Synthetic Route of Compounds $42-51^{a}$

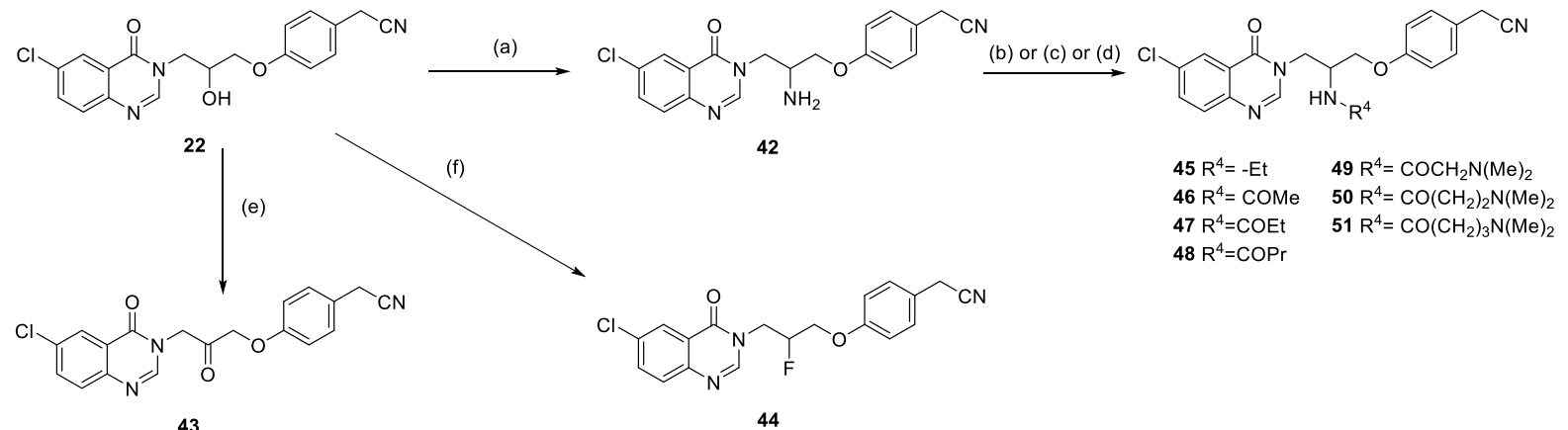

${ }^{a}$ Reagents and conditions: (a) $\mathrm{Ph}_{3} \mathrm{P}$, DIAD, DPPA, THF, $45{ }^{\circ} \mathrm{C}$, overnight; then $\mathrm{Ph}_{3} \mathrm{P}, \mathrm{NH}_{4} \mathrm{OH}, \mathrm{THF}: \mathrm{H}_{2} \mathrm{O}$, rt, overnight; $25 \%$. (b) 46-48 react corresponding anhydrides, $30{ }^{\circ} \mathrm{C}, \mathrm{DCM}, 3 \mathrm{~h}$; 90-95\%. (c) 49-51 react corresponding (dimethyl amino) substituted acids, PyBrop, trimethylamine, DMF, rt, $4 \mathrm{~h}$; 54-49\%. (d) Iodoethane, $\mathrm{Cs}_{2} \mathrm{CO}_{3}, \mathrm{CH}_{3} \mathrm{CN}, 60{ }^{\circ} \mathrm{C}$, overnight; $65 \%$. (e) Dess-Martin periodinane, DCM, rt, overnight; $76 \%$. (f) Dimethylamino-sulfur trifluoride, $45{ }^{\circ} \mathrm{C}, \mathrm{DCM}, 0.5 \mathrm{~h} ; 68 \%$.

Scheme 3. Synthetic Route of Compounds 54 and 55 to Explore the Influence of the Secondary Alcohol Present in $22^{a}$

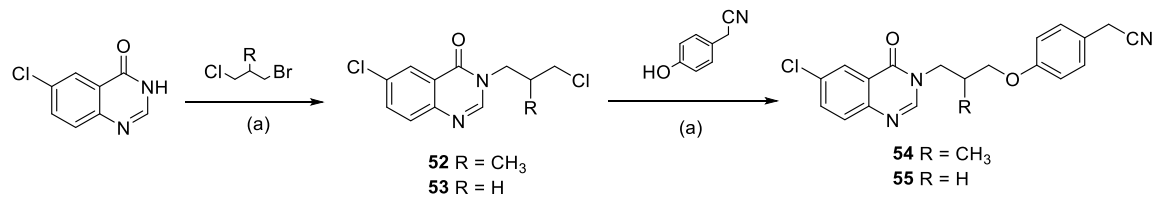

${ }^{a}$ Reagents and conditions: (a) $\mathrm{Cs}_{2} \mathrm{CO}_{3}$, TBAI, $\mathrm{CH}_{3} \mathrm{CN}, 100{ }^{\circ} \mathrm{C}$, overnight; yields (52-53: 70-72\%; 54-55: 40-49\%).

Scheme 4. Synthetic Route for 22 Derivatives with Various Nitrile Replacements ${ }^{a}$

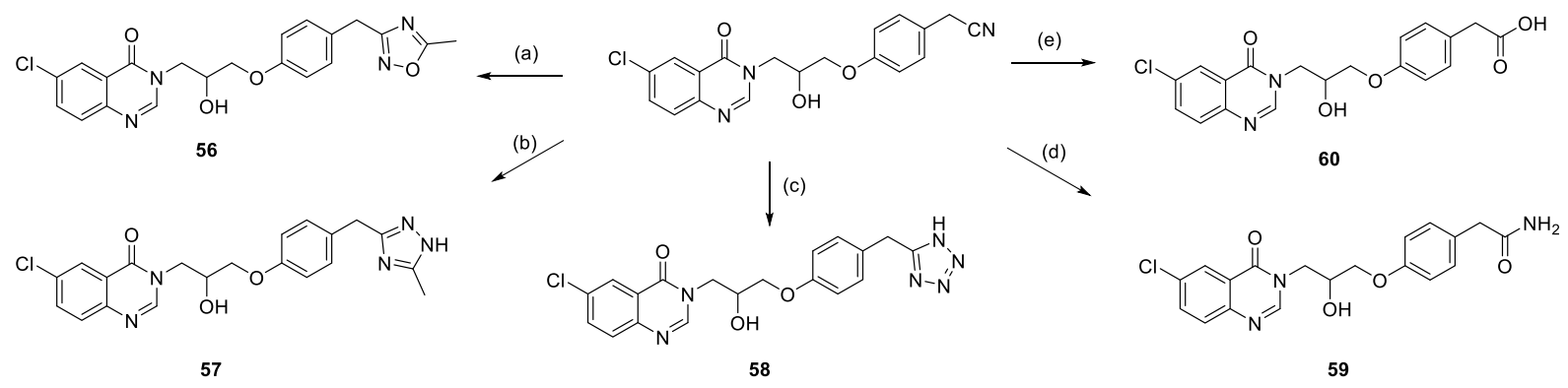

${ }^{a}$ Reagents and conditions (a) $\mathrm{NH}_{2} \mathrm{OH}$ (50\% in water), $\mathrm{NaOH}$, EtOH, $80{ }^{\circ} \mathrm{C}, 16 \mathrm{~h}$; then $\mathrm{Ac}_{2} \mathrm{O}$, toluene, $110{ }^{\circ} \mathrm{C}, 2 \mathrm{~h}$; $63 \%$. (b) Acetylhydrazine, sodium methoxide, $\mathrm{CH}_{3} \mathrm{OH}, 80{ }^{\circ} \mathrm{C}$, overnight; $15 \%$. (c) $\mathrm{NaN}_{3}, \mathrm{Et}_{3} \mathrm{~N} \cdot \mathrm{HCl}, \mathrm{DMF}, 130{ }^{\circ} \mathrm{C}$, overnight; $75 \%$. (d) $\mathrm{Cs}_{2} \mathrm{CO}_{3}, \mathrm{DMSO} 30 \% \mathrm{H}_{2} \mathrm{O}_{2}, \mathrm{rt}, 0.5$ h; $96 \%$. (e) $\mathrm{HCl}, \mathrm{H}_{2} \mathrm{O}$ reflux, overnight; $44 \%$.

substituted aniline tail, and the $\beta$-amino alcohol linker (Figure 1, A). To expedite the synthesis, 22 (Figure 1, B) was designed with a modified tail group bearing a phenyl ether linker in place of the substituted aniline present in $\mathbf{1}$. Compound 22 showed a 4-fold increase in potency compared to 1 ( $\mathrm{IC}_{50} 3.2 \pm$ $1.0 \mu \mathrm{M})$ and was therefore considered as a new starting point for development of this series. A robust synthetic strategy was employed to synthesize a series of analogues (22-41) with modified head or tail groups through an epoxide ring opening reaction between substituted quinazolin-4(3H)-ones 2-12 and 2-(methylphenoxy)oxirane derivatives $13-21$ to afford compounds 22-41 (Scheme 1). ${ }^{22}$

Subsequently to further explore the SAR, the secondary alcohol present in $\mathbf{2 2}$ was modified with isosteric replacements (Scheme 2). The amino derivative $\mathbf{4 2}$ was obtained from a Mitsunobu conversion of the hydroxyl group to azide ${ }^{23}$ which was subsequently reduced to the primary amine using the Staudinger reaction. ${ }^{24}$ Compound $\mathbf{4 2}$ was further functionalized either through a direct alkylation with iodoethane to give 45 or through conventional amide coupling reaction with either the corresponding anhydrides (46-48) or using PyBrop and triethylamine to afford 49-51. ${ }^{25}$ Oxidation of the secondary alcohol by the Dess-Martin reagent afforded ketone $43 .^{26}$ Finally, the fluorine derivative 44 was obtained from 22 using dimethylamino-sulfur trifluoride. ${ }^{27}$

To further explore the pharmacological requirement of the secondary alcohol, the alcohol was either removed 55 or replaced with a methyl group 54. 6-Chloroquinazolin-4(3H)one 2 was reacted with either 1-bromo-3-chloro-2-methylpropane or 1-bromo-3-chloropropane to afford $\mathbf{5 2}$ and $\mathbf{5 3}$ respectively, which were reacted with 2-(4-hydroxyphenyl)acetonitrile to provide $\mathbf{5 4}$ and $\mathbf{5 5}$ (Scheme 3).

The cyanomethyl group on the aromatic tail was also subject to replacement with 5-membered ring heterocycles. The nitrile group was reacted with hydroxylamine which was cyclized in the presence of acetic anhydride to yield 5-methyl-1,2,4 oxadiazole derivative $\mathbf{5 6} .^{28}$ While the triazole derivative $\mathbf{5 7}$ was obtained by reacting $\mathbf{2 2}$ with acetylhydrazine and sodium methoxide. ${ }^{29}$ The tetrazole derivative $\mathbf{5 8}$ was prepared through the reaction of 22 with $\mathrm{NaN}_{3}$ in DMF. Acid hydrolysis of the 
Scheme 5. Synthetic Route of Single Enantiomers 61 and $62^{a}$

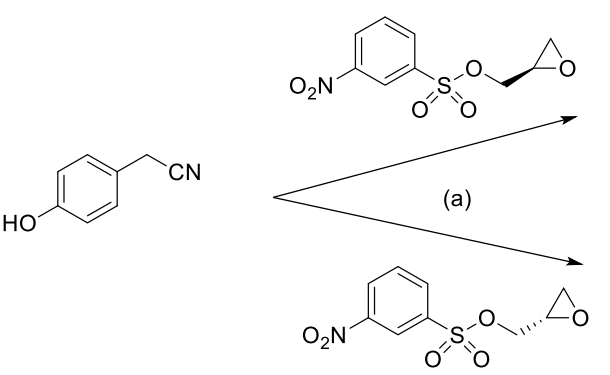<smiles>N#CCc1ccc(OCC2CO2)cc1</smiles>

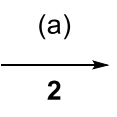<smiles>N#CCc1ccc(OC[C@@H](O)Cn2cnc3ccc(Cl)cc3c2=O)cc1</smiles><smiles>N#CCc1ccc(OC[C@H]2CO2)cc1</smiles>

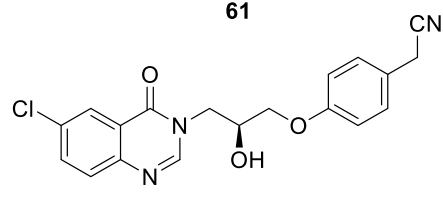

62

${ }^{a}$ Reagents and conditions: (a) $\mathrm{Cs}_{2} \mathrm{CO}_{3}, \mathrm{MeCN}$, reflux, overnight; yields $58-64 \%$.

nitrile to the corresponding carboxylic acid gave $\mathbf{6 0}$ and the carboxamide derivative $\mathbf{5 9}$ was prepared through hydrolysis by aqueous hydrogen peroxide in the presence of cesium carbonate (Scheme 4). ${ }^{30}$

Finally, the single enantiomers of $\mathbf{2 2}$ were prepared through reacting commercially available $(R)$ - and $(S)$-oxiran-2-ylmethyl 3-nitrobenzenesulfonates with 2-(4-hydroxyphenyl)acetonitrile to provide the corresponding epoxides that were subsequently reacted with 2 to afford $(R)$ - and $(S)$-enantiomers 61 and 62, respectively (Scheme 5). ${ }^{31}$ The percentages of enantiomeric excess (ee) of the products were $93.5 \%$ and $92.1 \%$ for the $(R)$ isomer 61 and $(S)$-isomer 62 respectively, as determined through chiral phase HPLC analysis.

Pharmacological Evaluation and Structure Activity Relationship. Screening of Commercial Compound Library. To provide initial insights into the exploration of the structure activity relationship within this new hit series, a SAR by catalogue study was initiated where a selection of commercially available close analogues sharing structural similarity of over 90\% with 22 were purchased and screened. The compounds bear slight modification of the quinazolin-4(3H)-one substituents and the aromatic tail of 22. Despite bearing close structural similarity to $\mathbf{2 2}$, these compounds proved inactive when screened at a $10 \mu \mathrm{M}$ spot test concentration (Table S1Supporting Information). However, these results provided an early indication of the tight SAR within this hit series and a design-make-test strategy to introduce preserved and minimal modifications was therefore implemented.

Compounds with Modified Headgroups. The SAR study started by introducing simple and conserved modifications in the quinazolinone ring (QZN) (Table 1). The chlorine atom on the QZN ring had a variable effect on biological activity, with the optimal position being substitution at the 6-position 22 as the 7-substituted chlorine analogue 23 had a 2-fold loss of activity. Analogues with chlorine atoms at the 5- or 8position (26 and 27, respectively) were inactive, likewise the disubstituted compounds $24(6,7-\mathrm{diCl})$ or $25(6,8-\mathrm{diCl})$. Replacement of the 6-substituted chlorine atom with the sterically more demanding bromine atom 28 improved the potency by 3 -fold $\left(\mathrm{IC}_{50} 0.8 \mu \mathrm{M}\right)$ and a similar effect was obtained with an electron withdrawing group such as $\mathrm{NO}_{2} 29$ $\left(\mathrm{IC}_{50} 0.6 \mu \mathrm{M}\right)$ or $\mathrm{CF}_{3} 31\left(\mathrm{IC}_{50} 0.6 \mu \mathrm{M}\right)$. It is noteworthy, that the 7-nitro substituted derivative 30 , as opposed to 23 , was completely inactive which is likely due to the size of the nitro group compared to the chlorine substituent. Branching off the QZN at the 2-position with a methyl group, 32 abolished
Table 1. Structures and Activities of 22 Analogues with Modified Head Groups 23-32 ${ }^{a}$<smiles></smiles>

\begin{tabular}{llllcl} 
& & & & remaining activity in PAO1-L \\
ID & \multicolumn{1}{c}{$\mathrm{R}^{1}$} & $\mathrm{R}^{2}$ & $\mathrm{X}^{1}$ & at $10 \mu \mathrm{M}(\mathrm{RA} \%)$ & $\mathrm{IC}_{50}(\mu \mathrm{M})$ \\
$\mathbf{2 3}$ & $7-\mathrm{Cl}$ & $\mathrm{H}$ & $\mathrm{CH}$ & $41.2 \pm 1.1$ & $6.7 \pm 0.3$ \\
$\mathbf{2 4}$ & $6,7-\mathrm{Cl}$ & $\mathrm{H}$ & $\mathrm{CH}$ & $\mathrm{NA}$ & \\
$\mathbf{2 5}$ & $6,8-\mathrm{Cl}$ & $\mathrm{H}$ & $\mathrm{CH}$ & $\mathrm{NA}$ & \\
$\mathbf{2 6}$ & $8-\mathrm{Cl}$ & $\mathrm{H}$ & $\mathrm{CH}$ & $\mathrm{NA}$ & \\
$\mathbf{2 7}$ & $5-\mathrm{Cl}$ & $\mathrm{H}$ & $\mathrm{CH}$ & $\mathrm{NA}$ & $0.8 \pm 0.2$ \\
$\mathbf{2 8}$ & $6-\mathrm{Br}$ & $\mathrm{H}$ & $\mathrm{CH}$ & $22.3 \pm 4.7$ & $0.6 \pm 0.1$ \\
$\mathbf{2 9}$ & $6-\mathrm{NO}_{2}$ & $\mathrm{H}$ & $\mathrm{CH}$ & $17.2 \pm 0.6$ & \\
30 & $7-\mathrm{NO}_{2}$ & $\mathrm{H}$ & $\mathrm{CH}$ & $\mathrm{NA}$ & $0.6 \pm 0.1$ \\
31 & $6-\mathrm{CF}_{3}$ & $\mathrm{H}$ & $\mathrm{CH}$ & $14.0 \pm 0.9$ & \\
32 & $6-\mathrm{Cl}$ & $\mathrm{Me}$ & $\mathrm{CH}$ & $84.1 \pm 3.2$ &
\end{tabular}

${ }^{a} \mathrm{NA}$ denotes no activity at a $10 \mu \mathrm{M}$ concentration.

activity, demonstrating the limited substitution possibility around the headgroup.

Compounds with Modified Tail Groups. As the manipulation of the headgroup of $\mathbf{2 2}$ provided a slight improvement for potency, a series of modifications were introduced at the level of the aromatic phenyl ring of $\mathbf{2 2}$ to explore the SAR of this region (Table 2). The cyanomethylene group proved important for biological activity at the para-position while the meta-substituted analogue 33 lacked biological activity. Moreover, aromatic nitriles, e.g. compounds 34 and 35 with paraand meta-benzonitrile respectively, exhibited significant loss of activity. Further, modification to the cyanomethylene group included the introduction of a cyclopropyl moiety 37 resulted in reduced activity, while extending the chain length by an extra methylene group 36 preserved the potency. Introduction of an ether bond between the phenyl and the cyanomethylene group 40 caused a slight reduction of activity. In some cases, disubstitution of the phenyl ring retained activity, in particular, ortho-substituted fluorine analogue $39\left(\mathrm{IC}_{50} 2.2 \mu \mathrm{M}\right)$ proved active when compared to meta-position 38 , which suffered a 2 fold loss in potency $\left(\mathrm{IC}_{50} 6.4 \mu \mathrm{M}\right)$. Extending the paraposition of the phenyl ring with a bulky phenoxy group 41 led to a $30 \%$ inhibition of $p q s$ activity at $1 \mu \mathrm{M}$ test concentration. One of the advantages of having the aliphatic nitrile is the versatility to convert it to various heterocycles to further explore SAR. While the oxadiazole replacement 56 retained 
Table 2. Exploration of the Tail Group of $22^{a}$

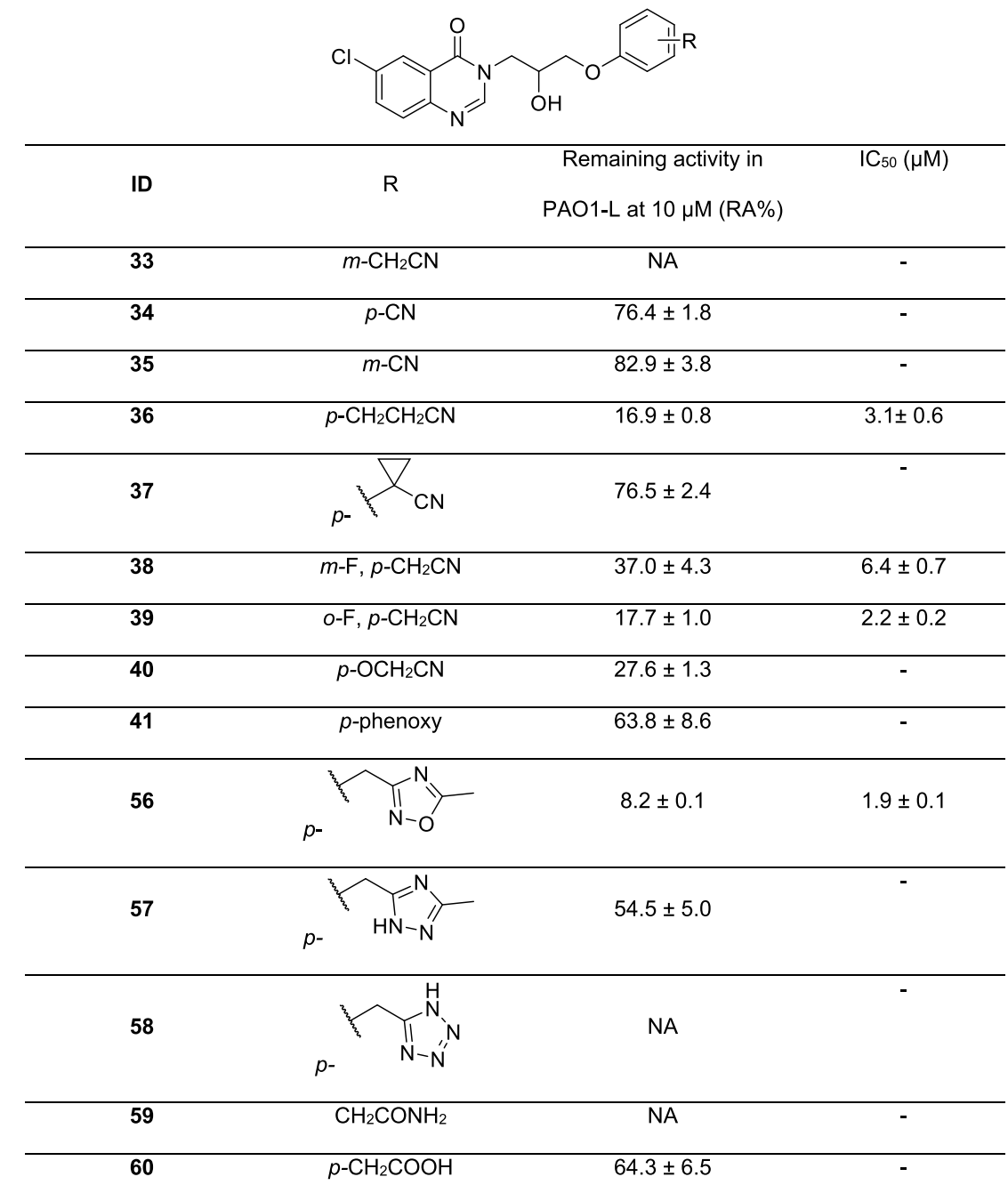

${ }^{a}$ NA denotes no activity at a $10 \mu \mathrm{M}$ concentration.

activity, triazole containing compound $\mathbf{5 7}$ demonstrated significant loss in activity and the tetrazole derivative $\mathbf{5 8}$ was totally inactive. Finally, hydrolysis of the nitrile group to its corresponding carboxamide led to inactive compound $\mathbf{5 9}$ while the carboxylic acid derivative $\mathbf{6 0}$ reduced activity (35\% inhibition at $10 \mu \mathrm{M})$. Despite all these modifications on the tail of 22, the para- substituted acetonitrile group proved to be the optimal substituent with a fluorine atom substituted at the ortho-position 39 having a comparable level of activity.

Analogues with Modified Linker Groups. It became apparent from the initial SAR investigation of the head and tail groups of $\mathbf{2 2}$ was limited to conservative modifications, therefore the focus of the evaluation moved to the linker group and particularly the secondary alcohol (Table 3 ). In this series of analogues, the head and tail moieties were fixed corresponding to those of $\mathbf{2 2}$, while the linker was varied and substituted. Oxidation of the alcohol to ketone $\mathbf{4 3}$ retained biological activity with $\mathrm{IC}_{50}$ of $4.3 \mu \mathrm{M}$. Conversely, substitution of hydroxyl with a fluorine atom 44 significantly reduced biological activity. Interestingly, replacing the alcohol with an amine $\mathbf{4 2}$ gave a compound with comparable activity ( $\mathrm{IC}_{50} 2.4 \mu \mathrm{M}$ ). However, alkylating the amine with an ethyl group 45 or acylation with small carboxylic acids (46-50)
Table 3. Modification of the Linker Group ${ }^{a}$<smiles>[R]C(COc1ccc(CC#N)cc1)Cn1cnc2ccc(Cl)cc2c1=O</smiles>

\begin{tabular}{|c|c|c|c|}
\hline ID & $\mathrm{R}$ & $\begin{array}{l}\text { remaining activity in } \\
\text { PAO1-L at } 10 \mu \mathrm{M}(\mathrm{RA} \%)\end{array}$ & $\mathrm{IC}_{50}(\mu \mathrm{M})$ \\
\hline 42 & $\mathrm{NH}_{2}$ & $10.5 \pm 1.2$ & $2.4 \pm 0.2$ \\
\hline 43 & $=\mathrm{O}$ & $16.6 \pm 1.7$ & $4.3 \pm 1.3$ \\
\hline 44 & $\mathrm{~F}$ & $67.8 \pm 11.9$ & \\
\hline 45 & $\mathrm{NHCH}_{2} \mathrm{CH}_{3}$ & $69.2 \pm 15.0$ & \\
\hline 46 & $\mathrm{NHCOCH}_{3}$ & $86.6 \pm 3.8$ & \\
\hline 47 & NHCOEt & $81.6 \pm 5.0$ & \\
\hline 48 & NHCOPr & $89.5 \pm 6.3$ & \\
\hline 49 & $\mathrm{NHCOCH}_{2} \mathrm{~N}\left(\mathrm{CH}_{3}\right)_{2}$ & NA & \\
\hline 50 & $\mathrm{NHCO}\left(\mathrm{CH}_{2}\right)_{2} \mathrm{~N}\left(\mathrm{CH}_{3}\right)_{2}$ & NA & \\
\hline 51 & $\mathrm{NH}(\mathrm{CH} 2)_{3} \mathrm{~N}\left(\mathrm{CH}_{3}\right)_{2}$ & $87.40 \pm 5.3$ & \\
\hline 54 & $\mathrm{H}$ & $88.6 \pm 8.5$ & \\
\hline 55 & $\mathrm{CH}_{3}$ & NA & \\
\hline 61 & (R)-OH & $11.0 \pm 0.8$ & $1.1 \pm 0.4$ \\
\hline 62 & $(S)-\mathrm{OH}$ & $43.5 \pm 4.9$ & $7.3 \pm 1.4$ \\
\hline
\end{tabular}

${ }^{a}$ NA denotes no activity at a $10 \mu \mathrm{M}$ concentration. 
a)
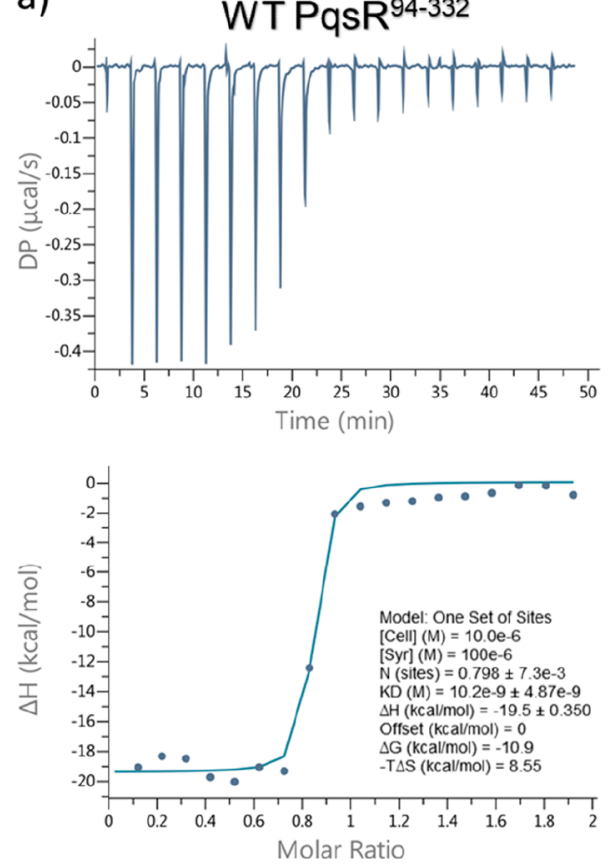

b)

\section{Isothermal profile of 61}

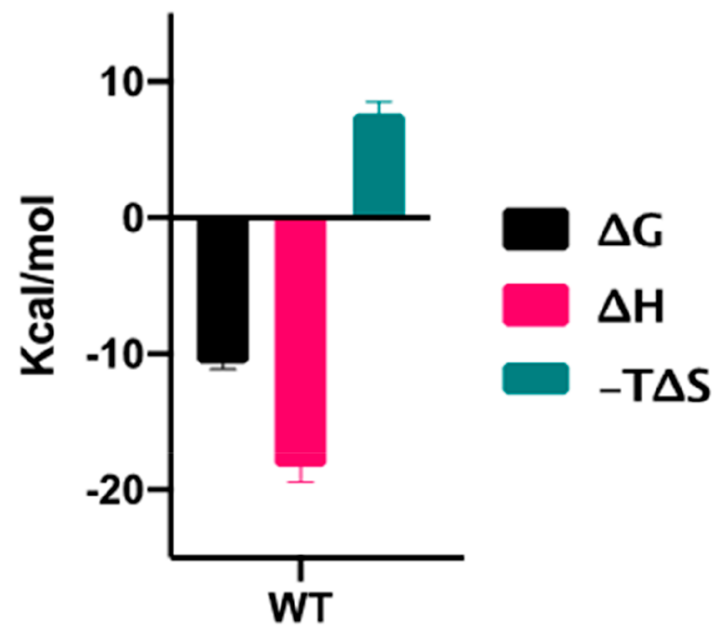

Figure 2. Isothermal titration calorimetry analysis. (a) ITC thermogram of $\mathbf{6 1}$ binding to $\mathrm{PqsR}^{\mathrm{LBD}}$; (b) thermodynamic profiles of $\mathbf{6 1}$ titrations into WT. Titrations for WT constructs performed in at least two separate experiments.

a)

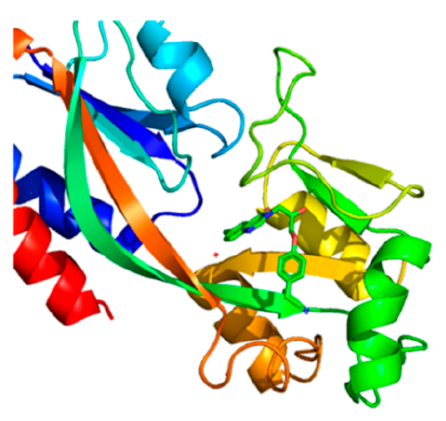

d)

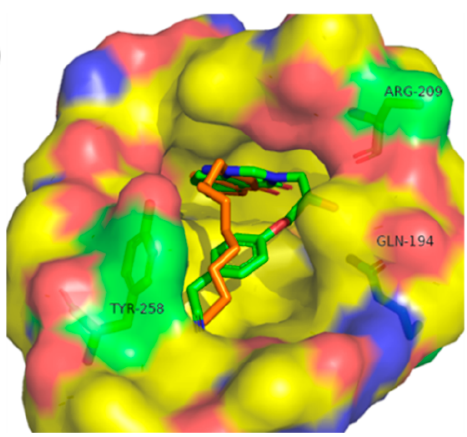

b)
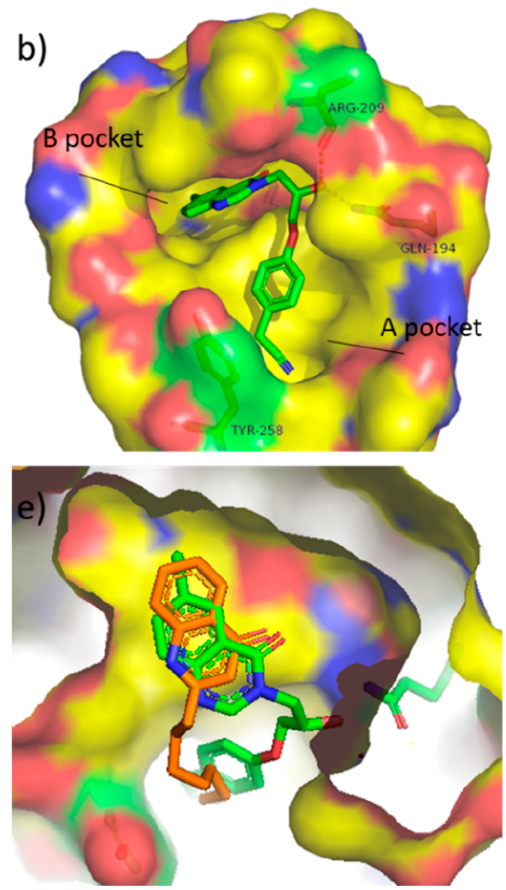
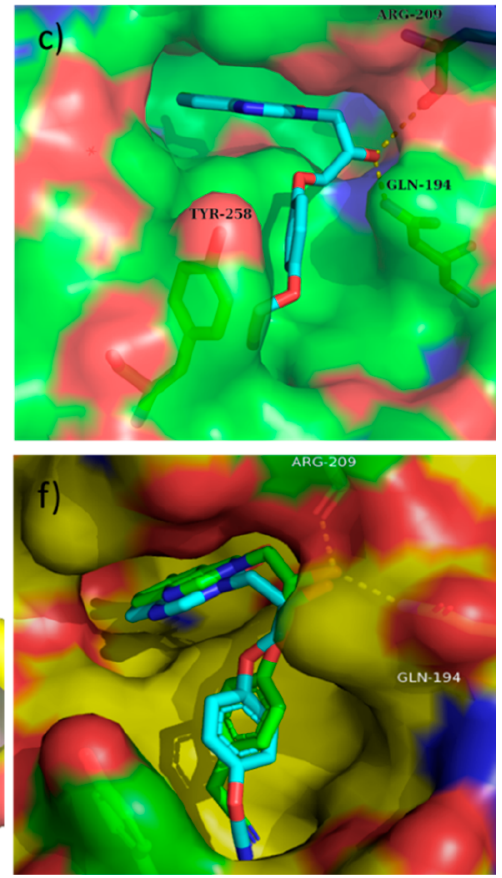

Figure 3. Crystal structures of PqsR ${ }^{\mathrm{LBD}}$ to various ligands: (a) Ribbon representation of PqsR ${ }^{\mathrm{LBD}}$ crystallized with 61; (b) Surface representation of $\mathrm{PqsR}^{\mathrm{LBD}}$ with 61 (green sticks) showing (A and B) pockets (PDB 7O2T); (c) Surface representation of PqsR ${ }^{\mathrm{LBD}}$ with 40 (cyan sticks) showing (PDB 7O2U); (d) Overlay of NHQ (represented as orange sticks, PDB 4JVD ${ }^{32}$ ) and 61 in the ligand binding domain; (e) Overlay of NHQ (represented as orange sticks) and $\mathbf{6 1}$ (represented as green sticks) in the B pocket of the ligand binding domain; (f) Overlay of 61 and 40 in the ligand binding domain.

resulted in a loss of activity. In a similar fashion, removing the hydroxyl group $\mathbf{5 4}$ or substituting it with a methyl group $\mathbf{5 5}$ removed all biological activity.

To conclude the SAR study, the chiral resolution of the alcohol was examined through the synthesis of the $(R)-(61)$ and $(S)$-enantiomers (62) (Scheme 4$)$. The $(R)$-enantiomer
61 proved more active ( $\mathrm{IC}_{50}$ of $\left.1 \mu \mathrm{M}\right)$ over the $(S)$ enantiomer, which was 7 -fold less active $\left(\mathrm{IC}_{50}\right.$ of $\left.7 \mu \mathrm{M}\right)$.

In conclusion, the extensive SAR study demonstrated the very tight structural requirements for activity within this hit series. It is noteworthy that $\mathbf{6 1}$, the $(R)$-enantiomer of $\mathbf{2 2}$, proved to be one of the most potent inhibitors and the remainder of our study centered on this compound. 


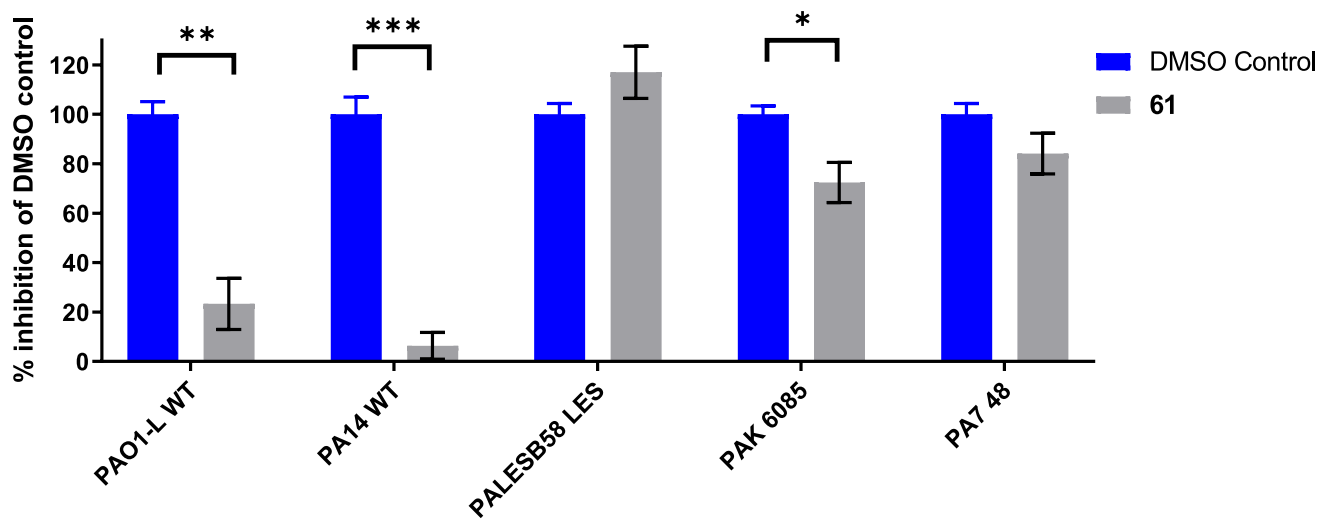

Figure 4. Pyocyanin quantification assay. Bar chart representing pyocyanin production in laboratory and clinical strains: blue bars refer to untreated controls, gray bars represent treatment with $3 \mu \mathrm{M}$ of 61 . The data was normalized to a negative control of DMSO in each strain. The error bars represent the standard deviation of biological triplicates. The statistical significance was performed using paired $t$ test analysis (Graphpad 9.0).

Isothermal Titration Calorimetry Assay. As the bioreporter assay provides data about the inhibition levels of the $p q s$ system but does not provide direct evidence that the compounds are binding to PqsR, it was paramount to confirm the binding using an orthogonal approach. For this purpose, we used isothermal titration calorimetry (ITC) which also enables the measurement the binding thermodynamics parameters between $\mathrm{PqsR}^{\mathrm{LBD}}$ and 61. This analysis revealed that 61 has strong PqsR ${ }^{\mathrm{LBD}}$ affinity with dissociation constant $\left(K_{\mathrm{d}}\right.$ of $10 \mathrm{nM}$ ) (Figure 2) and a stoichiometry of 1:1.

Crystal Structure of PqsR Antagonists with PqsR ${ }^{\mathrm{LBD}}$. To gain a detailed insight into the molecular interaction of the antagonists with PqsR, the X-ray cocrystal structures complexed with $\mathbf{6 1}$ and $\mathbf{4 0}$ were obtained by ligand soaking (Figure $3 \mathrm{a}, \mathrm{b}, \mathrm{c}$, and $\mathrm{f}$ ). As previously reported, ${ }^{32} \mathrm{PqsR}^{\mathrm{LBD}}$ compromises a deep pocket (B pocket) which usually accommodates the quinolone part of the autoinducer, as exemplified in the case of 2-nonyl-4-quinolone (NHQ), while the superficial pocket (A pocket) contains the aliphatic side chain (Figure 3d, e). ${ }^{32}$ The structures revealed that the quinazolinone moiety of $\mathbf{6 1}$ and $\mathbf{4 0}$ reside in the B pocket, in a similar manner to $\mathrm{NHQ}$ surrounded by aliphatic residues $\left(\mathrm{Ala}^{102}, \mathrm{Ala}^{168}, \mathrm{Ile}^{207}\right.$, Ile ${ }^{208}$ ) while the hydroxyl group establishes hydrogen bonding with glutamine $\left(\mathrm{Glu}^{194}\right)$ and arginine $\left(\mathrm{Arg}^{209}\right)$ (Figure $3 \mathrm{~b}$ and $\mathrm{c}$ ). The aromatic tail adopted a similar conformation to NHQ sustaining hydrophobic interaction while the nitrile group is oriented toward the tyrosine $\mathrm{Tyr}^{258}$. It was noted that there was a slight shift of the nitrile group position between $\mathbf{6 1}$ and $\mathbf{4 0}$ likely to the presence of the ether bond in the latter with elevated $\mathrm{B}$ factors suggesting the nitrile is thermally mobile within pocket A. However, both compounds maintained the same conformation overall and shared the electrostatic interaction with the same residues.

Pharmacological Evaluation of PqsR Inhibitors. Pyocyanin Quantification Assay. PA produces a range of redox active phenazine derived molecules, among these pyocyanin is one of the most studied compounds which plays various roles in virulence, gene expression, biofilm formation as well as hosttissue damage. ${ }^{33}$ Pyocyanin biosynthesis is achieved through the activation of the phenazine phz operons which are under the regulation of the $p q s$ system. ${ }^{13,34,35}$ Consequently, the attenuation of $p q s$ system leads to a reduction of pyocyanin production, and hence quantification of pyocyanin levels serves as an indirect readout for the inhibition caused by PqsR antagonists. For this purpose, the expression of pyocyanin in the presence of 61 at $3 \mu \mathrm{M}$ (3-fold the $\mathrm{IC}_{50}$ value) was measured on PAO1-L and PA14 lab strains showing a reduction of $80 \%$ and $95 \%$ of pyocyanin levels respectively compared to untreated controls (Figure 4). The study was further extended to validate the effect of $\mathbf{6 1}$ on a selection of clinical isolates with different genomic backgrounds where PALESB58, PAK6085, and PA748 clinical isolates were selected as representatives (Figure 4). ${ }^{36}$ The study concluded that these isolates were less sensitive to the effect of 61 with only the PAK6085 strain showing a significant reduction of $27 \%$.

Alkyl Quinoline Quantification Assay. To further investigate the impact of the PqsR inhibitor 61 on the expression of the pqsABCDE operon, production of HHQ and PQS signals was quantified using LCMS/MS analysis. Similar to the pyocyanin assay, the effect of $\mathbf{6 1}$ on alkylquinoline signal production was quantified in lab strains as well the three clinical isolates mentioned previously using a concentration that equals 3 times the corresponding $\mathrm{IC}_{50}$. The results demonstrated that $\mathbf{6 1}$ significantly inhibited HHQ and PQS production in PAO1-L $(>90 \%)$ and PA14 $(\sim 50 \%)$ in agreement with the pyocyanin data, although to a lesser extent in PA14 (Figure 5). Once more the PAK6085 clinical isolate was the only one to respond to 61 although to a lesser extent than the lab strains whereas PALESB58 and PA748 did not show a significant response.

Effect of 61 on PA Biofilm Formation. Biofilms are highly resilient to antibiotic treatments. Quorum sensing has been shown to play a critical role in biofilm development. ${ }^{37}$ To examine whether $\mathbf{6 1}$ could affect biofilm formation and potentiate antibiotic activity, pre-established PAO1-L biofilms $(48 \mathrm{~h})$ grown in the presence of 61 were treated with the broad-spectrum antibiotic Ciprofloxacin (Cip) and their viability investigated using LIVE/DEAD BacLight bacterial viability staining and confocal laser scanning microscopy (CLSM). The effect of $\mathbf{6 1}$ on biofilm viability as a single treatment or in combination with Cip was measured at two different time points $(5,16 \mathrm{~h})$ to establish whether this PqsR antagonist could enhance the effect of the antibiotic. It was evident that $\mathbf{6 1}$ on its own had no significant effect on biofilm viability, however, when combined with $\mathrm{Cip}$ it showed significant potentiation of the antibiotic effect at $5 \mathrm{~h}$ of incubation (Figure 6). However, this was not observed at 16 


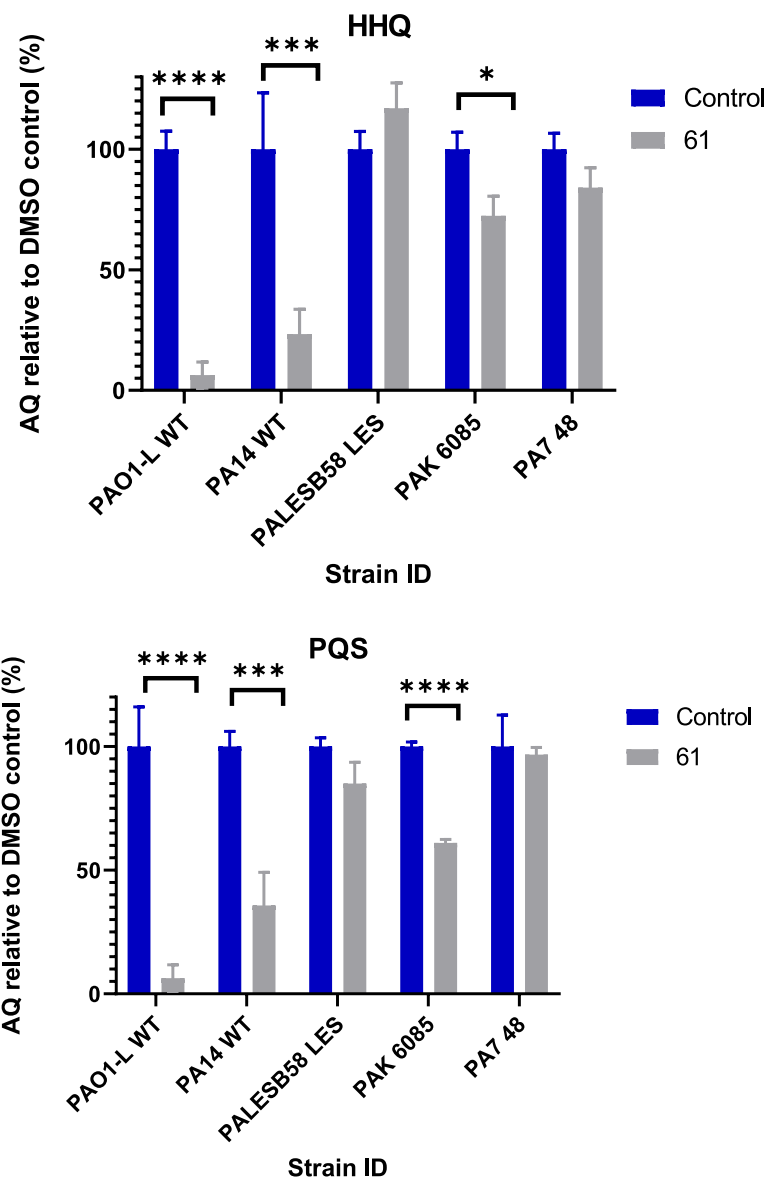

Figure 5. Alkyl quinolone quantification assay. Relative quantification of AQs produced by different PA strains. Blue bars represent control while gray bars indicate treated samples. Error bars represent the standard deviation of biological triplicates. Data was normalized against the DMSO control group. The statistical significance was performed using paired $t$ test analysis (Graphpad 9.0).

$\mathrm{h}$ where Cip activity matched that of the combined therapy (Cip and 61).

In Vivo Efficacy of PqsR Antagonist 61. To evaluate the impact 61 in attenuating disease, an in vivo infection model using Galleria mellonella was used. The study started by evaluating the toxicity of 61 on larvae at 10 and $100 \mu \mathrm{M}$ concentrations over 3 days. Neither of the concentrations tested had an impact on larvae survival (Figure 7A). The effect of 61 as a single treatment and in combination with Cip was then evaluated. Larvae inoculated with PAO1-L without treatment showed a median survival time of $12 \mathrm{~h}$, and addition of 61 did not result in a change in mortality rate (Figure 7B). There was a reduction in the overall mortality and mortality rate with the addition of Cip compared to PAO1-L, and this was further reduced with addition of $\mathbf{6 1}$ in combination with Cip. Therefore, $\mathbf{6 1}$ was able to potentiate the action of Cip in the treatment of wax worm PA infections. To determine the effect of strain variation PAO1-N was utilized, and the effect of 61 as a single treatment and in combination with Cip was evaluated (Figure 7B). Larvae inoculated with PAO1-N had a median survival time of 19 and $20.5 \mathrm{~h}$ when treated with 61. A significant reduction $(p<0.0001)$ was observed with the treatment with Cip with a median survival time of $37 \mathrm{~h}$; this was further enhanced with a combination of 61 and Cip with 21 larvae surviving at the end point.

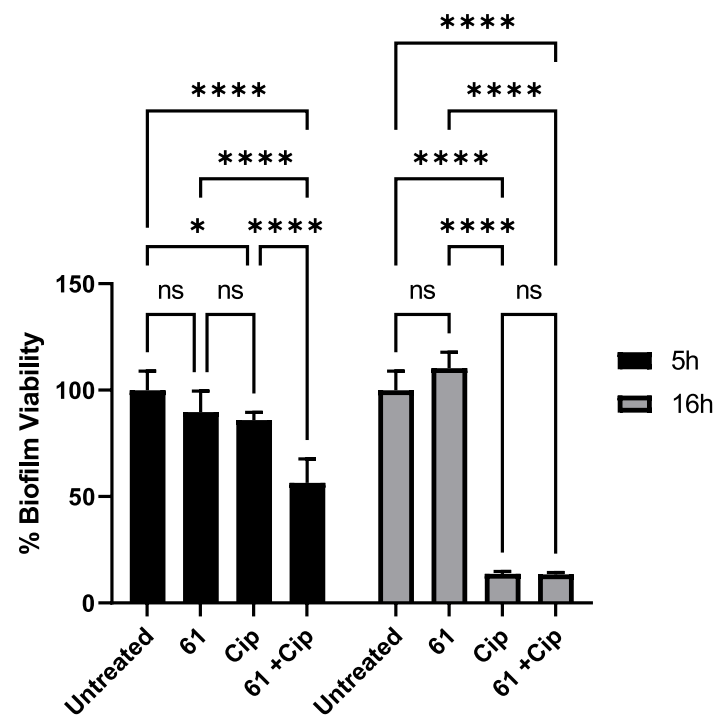

Figure 6. Biofilm viability assay. Bar chart showing PAO1-L biofilm viability quantified after treatment with different conditions for 5 or $16 \mathrm{~h}$. The concentrations of the drugs used were ciprofloxacin $60 \mu \mathrm{g} /$ $\mathrm{mL}$ (CIP), $6110 \mu \mathrm{M}$. The statistical significance was performed using paired $t$ test analysis (Graphpad 9.0).

Cytotoxicity Study of 61 on Lung Epithelial Cells. The effect of 61 on A549 lung epithelial cell cytotoxicity assay was examined to evaluate the suitability of this inhibitor for further development. This study concluded that PqsR inhibitor $\mathbf{6 1}$ did not exhibit any cytotoxic effect up to a concentration of 300 $\mu \mathrm{M}\left(\mathrm{LD}_{50}>300 \mu \mathrm{M}\right)$ which is around 300 -fold greater than the corresponding $\mathrm{IC}_{50}$ in PAO1-L $(1 \mu \mathrm{M})$.

\section{DISCUSSION}

In this study, we reported the discovery of $(R)-2-(4-(3-(6-$ chloro-4-oxoquinazolin-3(4H)-yl)-2-hydroxypropoxy)phenyl)acetonitrile $\mathbf{6 1}$ as a novel PqsR inhibitor. The starting hit $\mathbf{1}$, which originated from a hit identification campaign, demonstrated weak $p q s$ inhibition in the bioreporter whole cell assay with an $\mathrm{IC}_{50}$ of $13 \mu \mathrm{M}$. To facilitate the synthesis of analogues, compound 22 was proposed and shown to be with 4-fold more active than $1\left(\mathrm{IC}_{50}=3.1 \mu \mathrm{M}\right)$. To progress this hit to a lead stage, an extensive structure activity relationship was performed on $\mathbf{2 2}$ and concluded that even minor structural alterations could lead to obliteration of potency. The key findings of SAR can be summarized as follows: (I) The acetonitrile group at the para-position of the phenyl ring is important for activity and the overall potency can be marginally improved with a meta-fluorine atom, (II) substitution at the 6-position of the quinazolin- $4(3 \mathrm{H})$ was preferred for a halogen or an electron withdrawing group, (III) the hydroxyl group of the linking group is preferred and the $(R)$-enantiomer 61 possesses the improved activity compared to the $(S)$-enantiomer. Nevertheless, inhibitors of the $\mathrm{P}_{p q s A}$-lux reporter could potentially be targeting the AQ biosynthetic enzymes rather than PqsR. To further confirm that $\mathbf{6 1}$ is acting as a PqsR inhibitor, an ITC analysis was used to determine the thermodynamic parameters of binding and to aid the understanding of the biomolecular interactions. This showed that 61 was able to bind to $\mathrm{PqsR}^{\mathrm{LBD}}$ with a $K_{\mathrm{d}}$ of $10 \mathrm{nM}$. These outcomes were further confirmed by the X-ray crystal structures of 61 and 40 with $\mathrm{PqsR}^{\mathrm{LBD}}$. These structures revealed that the binding is mainly governed by hydrophobic 

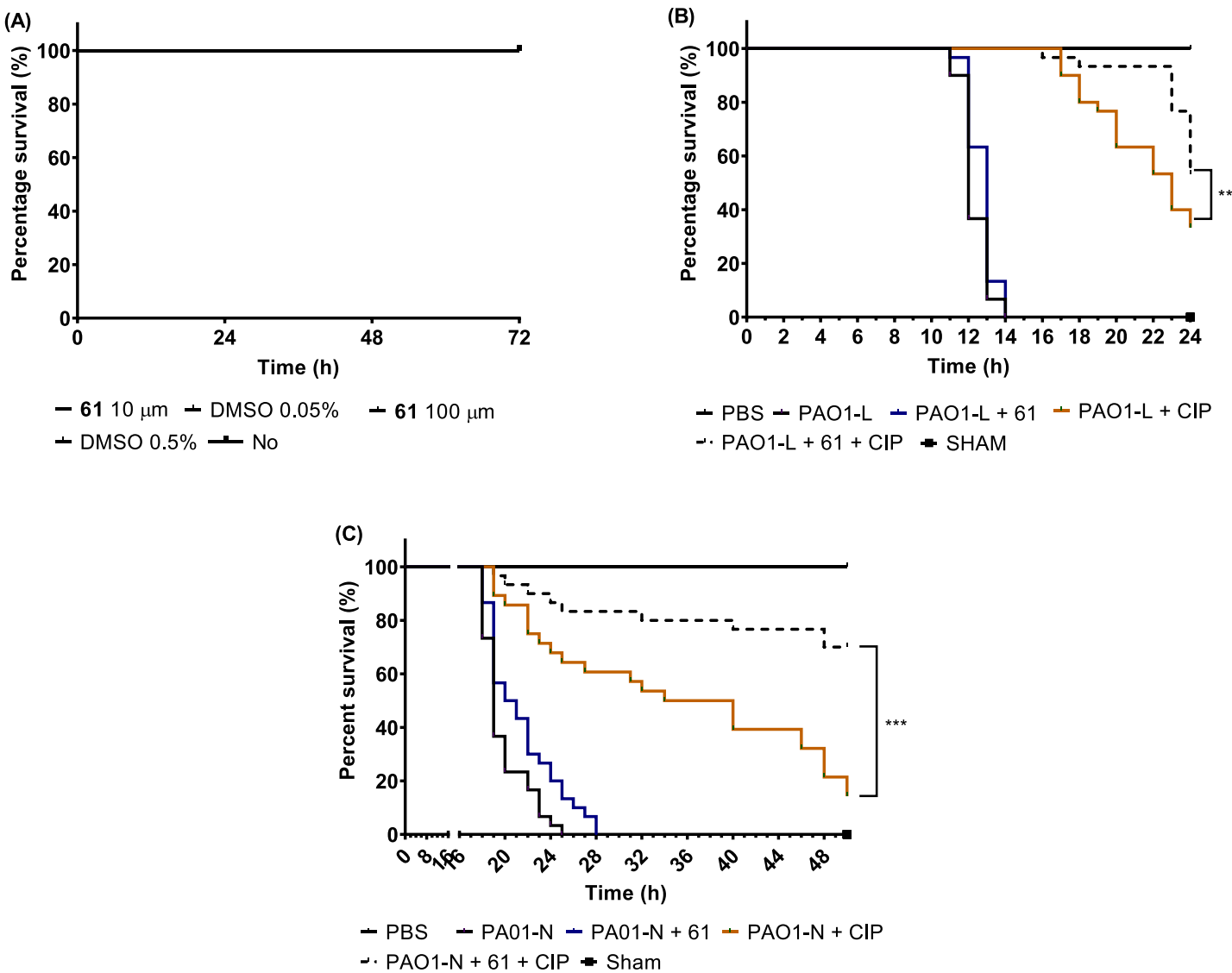

Figure 7. Galleria mellonella survival assays. (A) Three-day survival monitoring with $10 \mu \mathrm{M}$ and $100 \mu \mathrm{M} 61$. DMSO controls of $0.05 \%$ and $0.5 \%$ performed to determine any influence on survival of larvae as this is the final concentration of DMSO in 10 and $100 \mu \mathrm{M}$ of 61 . (B) Galleria mellonella survival with/without $10 \mu \mathrm{M}$ of 61 treatment and with/without Cip treatment A median survival time of $12 \mathrm{~h}$ was observed with and without 61 treatment alone. A small significant trend in mortality rate and final end point was observed for the combination of Cip + $\mathbf{6 1}$ compared to Cip treatment only. ** $p=0.0085$. (C) Galleria mellonella survival with/without $10 \mu \mathrm{M}$ of 61 treatment and with/without Cip treatment. A median survival time of $19 \mathrm{~h}$ was observed with PAO1-N and $20.5 \mathrm{~h}$ with PAO1-N +61 . A significant improvement in survival rate was observed with Cip treatment $* * * * p<0.0001$, further enhanced with addition of $61^{* * *} p=0.0002$. Statistical analysis performed by Kaplan-Meier estimate and Gehan-Breslow-Wilcoxon test, $n=30$, over three independent biological replicates.

interactions and supported with electrostatic interactions at the level of the side chains of $\mathrm{Gln}^{194}$ and $\mathrm{Arg}^{209}$. Despite the interaction with $\mathrm{Gln}^{194}$ being reported previously in the literature, the interaction with $\mathrm{Arg}^{209}$ was new and unique to these structures. It is worth mentioning that the quinazolinone head groups in $\mathbf{6 1}$ and $\mathbf{4 0}$ reside in different orientation to our previously reported quinazolinone derived pqs inhibitors. ${ }^{19}$ The latter compounds were positioned in a conformation that allows the carbonyl group to be in a close proximity to $\mathrm{Thr}^{265}$. Further investigation is needed to pinpoint whether the different ligand conformation in the receptor contributed to the enhanced potency.

These findings along with previously reported structures can be employed to fine-tune potency further. ${ }^{18,19,32,38}$ Subsequently, the work moved to examine the effect of 61 in a series of phenotypic assays, such as pyocyanin and AQ signal quantification. Most importantly, these assays were performed, unlike the majority of published work in relation to $p q s$ inhibition, in a selection of PA isolates with different genetic backgrounds including lab and clinical strains. This is of exceptional importance in antibacterial drug discovery as the potency of inhibitors may vary significantly in a strain dependent manner which could lead to an inevitable and costly pitfall if not discovered early. ${ }^{39}$ Indeed, while $\mathbf{6 1}$ showed superior activity in suppressing PA phenotypes in lab strains (PAO1-L and PA14), it failed to maintain this effect in clinical isolates. The sequence alignment of PqsR in these strains was performed (see the Supporting Information) and suggested that the sequence is mostly preserved apart from $\mathrm{Ala}^{314}$ to $\mathrm{Val}$ mutation in PA14 which is distant from the ligand binding site. The reasons behind the difference in activity of strains was not pursued in this study, but it could be due to variation in the level of activity of $p q s$ operon in these strains or variation in permeability issues through the bacterial membrane and the presence of efflux pumps on the bacterial cell membrane. ${ }^{40}$ It is noteworthy that all the clinical strains originated from cystic fibrosis patients which reflects the multidrug resistant nature of the microbiome associated with this disease. ${ }^{36,41}$

Another important phenotype of PA is the ability to form antimicrobial resistant biofilms. To this extent, PA biofilms were treated with $\mathbf{6 1}$ as sole agent and also in combination with ciprofloxacin. While $\mathbf{6 1}$ demonstrated a slight effect as single treatment, it was able to potentiate ciprofloxacin treatment at $5 \mathrm{~h}$ but not at $16 \mathrm{~h}$ time points. The reason behind the difference in efficacy was not investigated, but it could be potentially due to ciprofloxacin reaching maximal efficacy at the experimental end point $(16 \mathrm{~h})$ shadowing the effect of 61. This suggests that this PqsR inhibitor may be 
more effective as an adjuvant for the initial stages of treatment. Further work is needed to establish the impact of treatment at different time points and concentrations, but this is beyond the scope of the current study. Previous reports have shown that PqsR inhibition can increase the sensitivity of mature PA biofilms to antibiotics; however, the biofilm extracellular matrix is a major barrier to the transport of these inhibitors. ${ }^{42}$ As an analogy, our previously published thioacetamide derived $p q s$ inhibitors failed to show any inhibitory effect on PA biofilms despite the high potency in planktonic growth. ${ }^{18}$ Small molecule penetration to biofilms can be improved applying drug delivery approaches such as biofilm responsive nanoparticles. ${ }^{43}$ Indeed, the use of $\mathrm{pH}$ responsive nanoparticles has been shown to increase the penetration and efficacy of QS inhibitors combined with ciprofloxacin in mature biofilms. ${ }^{44}$ Despite no measures being applied in our study to improve 61 penetration through PA biofilms, our results indicate that this QS inhibitor could improve conventional antibiotic therapy against recalcitrant bacterial-biofilm centered infections.

To conclude this work, a G. mellonella infection model was employed to investigate the effect of 61 on mortality rate due to PA infections. ${ }^{45}$ In agreement with the previous observation in biofilms, 61 showed no effect on mortality rate as a sole agent; however, when combined with ciprofloxacin, 61 was able to improve the survival compared to ciprofloxacin alone in PAO1-L and PAO1-N inoculated wax worms. In this study the quorum sensing inhibitor 61 was unable to significantly alter the survival of wax worms in both PAO1-L and PAO1-N, this is in contrast to the study performed by D'angelo and colleagues $^{46}$ who showed that an approved FDA drug Clofoctol that is a probable PqsR inhibitor was able to reduce the mortality of PAO1 infected wax worms. It must be noted that the wax worms used in the D'angelo study $(500 \mathrm{mg})$ were significantly larger than those used in this study $(250 \mathrm{mg})$ and both PA strains used in this study caused $100 \%$ mortality. It is noteworthy that $\mathbf{6 1}$ showed a low cytotoxic profile when tested on human lung carcinoma epithelial cells A549 $\left(\mathrm{LD}_{50}>300\right.$ $\mu \mathrm{M})$ supporting its suitability for further preclinical development. In summary, this study delivered a robust evaluation of 61 as a PqsR antagonist using chemical, biophysical, structural and biological means and provided a solid foundation to enhance the potency and spectrum of this series in future lead optimization studies.

\section{METHODS}

Molecular Docking. Preparation of Protein and Receptor Grid Generation. The X-ray crystal structure of PqsR ligand binding domain in complex with the QZN inhibitor (PDB ID 4JVI) was used as a protein template. The protein was prepared using the protein preparation wizard (Small-Molecule Drug Discovery Suite 2017-4, Schrödinger, LLC, New York, NY, USA), where hydrogen atoms were added, water molecules were removed, and the correct bond order was assigned to the amino acid residues. Afterward, a receptor grid generation was performed, based on defined residues around the ligand binding sites: (Ala102, Pro129, Ile149, Thr166, Ala 168, Val 170, Ile186, Ie189, Gln194, Ser196, Leu196, Leu197, Leu207, Leu208, Pro210, Val211, Trp234, Gly235, Pro238, Ser255). The inner grid box was set to $10 \AA$, while the outer box was $20 \AA$.

Ligand Preparation. The chemical structures of the inhibitors were sketched using ChemDraw (Version 16.0.1.4, PerkinElmer informatics) via an SDF file. The LigPrep module
(Small-Molecule Drug Discovery Suite 2017-4, Schrödinger, LLC, New York, NY, USA) was then used for final preparation of ligands into their lowest energy $3 \mathrm{D}$ conformations. The partial atomic charges were assigned to the molecular structures, using the 2005 implementation of the OPLS-AA force field. These energy-minimized structures were used for Glide docking.

Molecular Docking. The "Extra Precision" (XP) mode of Glide docking (Small-Molecule Drug Discovery Suite 2017-4, Schrödinger, LLC, New York, NY, USA) was used to perform all docking calculations, using the OPLS-AA 2005 force field. The scale factor of 1.0 for van der Waals radii was applied to atoms of protein with absolute partial charges of less than or equal to 0.25 . The number of positions per ligand was set to five, after energy minimization. The best docked structures were chosen using an XP Glide Score (XP Gscore) function as well as visual observations.

Chemistry Procedures and Compound Characterization. Reagents and solvents were purchased from SigmaAldrich, Alfa Aesar, Fluorochem, and Fisher Scientific. Nuclear magnetic resonance was performed at ambient temperature using a Bruker AV400 spectrometer $\left(400 \mathrm{MHz}\right.$ for $\mathrm{H}^{1}, 101$ $\mathrm{MHz}$ for $\left.\mathrm{C}^{13}\right)$. The samples were prepared in deuterated solvent: $\mathrm{DMSO}-d_{6}$ and $\mathrm{CDCl}_{3}$. Chemical shifts $(\delta)$ were recorded in ppm, and coupling constants $(J)$ were recorded in Hz. The spectra were analyzed using MestReNova 12.0.1 software. Mass spectrometry: Analytical HPLC were performed on a Shimadzu UFLCXR system coupled to an Applied Biosystems API2000. Three columns thermostated at $40{ }^{\circ} \mathrm{C}$ were used. Column one: Phenomenex Gemini-NX $3 \mu \mathrm{m} \mathrm{C18}$, $50 \times 2 \mathrm{~mm}$. Column two: Phenomenex Luna $3 \mu \mathrm{m}$ (PFP2) $110 \mathrm{~A}, 50 \times 2 \mathrm{~mm}$. Column three: Waters X terra MS C8 2.5 $\mathrm{m}, 4.6 \times 30 \mathrm{~mm}$. Flow rate: $0.5 \mathrm{~mL} / \mathrm{min}$. UV detection at 220 (channel 2) and $254 \mathrm{~nm}$ (channel 1). Analytical HPLC for final compounds were performed on a Shimadzu UFLCXR system coupled to a mass spectrometer (Applied Biosystems API2000). Three columns thermostated at $40{ }^{\circ} \mathrm{C}$ were used (column 1: C8-110A, $50 \times 2 \mathrm{~mm}(\operatorname{method} 1)$; column 2: Luna $3 \mathrm{u}(\mathrm{PFP} 2) 110 \mathrm{~A}, 50 \times 2 \mathrm{~mm}(\operatorname{method} 2)$; column 3: C18 50 $\times 2 \mathrm{~mm}(\operatorname{method} 3))$. The flow rate was set to $0.5 \mathrm{~mL} \cdot \mathrm{min}^{-1}$. UV detection was performed at 254 (channel 1) and $220 \mathrm{~nm}$ (channel 2). The eluting gradient was as follows: preequilibration run for $1 \mathrm{~min}$ at $10 \% \mathrm{~B}, 10$ to $98 \% \mathrm{~B}$ in $2 \mathrm{~min}$, $98 \%$ for $2 \mathrm{~min}, 98$ to $10 \% \mathrm{~B}$ in $0.5 \mathrm{~min}$, then $10 \% \mathrm{~B}$ for $1 \mathrm{~min}$ (where solvent $\mathrm{A}$ is $0.1 \%$ formic acid in water and solvent $\mathrm{B}$ is $0.1 \%$ formic acid in $\mathrm{MeCN}$ ). All compounds reported here are with purity over $95 \%$ unless otherwise mentioned. Chromatography: Thin-layer chromatography (TLC) was performed, UV light and standard TLC stains were used to visualize the Merck Silica gel $60 \AA \mathrm{F}_{254}$ plates. Compounds were purified via column chromatography using either a Thompson pump or normal phase Interchim Puriflash prepacked cartridges filled with $50 \mu \mathrm{M}$ silica, or a glass column using Sigma-Aldrich silica gel $60 \AA$ (230-240 $\mu \mathrm{m})$.

Chiral HPLC was performed on Dionex ICS-3000 with an Ultimate-3000 detector equipped with Lux $5 \mu \mathrm{m}$ Cellulose-4, LC column $250 \times 4.6 \mathrm{~mm}$ column.

General Procedure (1) for preparation of epoxides 12, 18, 19,21 . To a stirred solution of different phenols (1 equiv) in $\mathrm{MeCN}(50 \mathrm{~mL})$ was added $\mathrm{Cs}_{2} \mathrm{CO}_{3}$ (2 equiv) and then epichlorohydrin ( 1.2 equiv). The reaction mixture was refluxed at $85{ }^{\circ} \mathrm{C}$ for $16 \mathrm{~h}$. The mixture was then filtered and purified 
using column chromatography with PE:EtOAc 8:2 as the eluent.

2-(4-Oxiran-2-ylmethoxy)phenyl)acetonitrile 12. The title compound was prepared according to general procedure (1) using 4-hydroxyphenylacetonitrile $(20 \mathrm{~g}, 0.15 \mathrm{~mol})$ as the starting material. White solid (7g, 25\%). ${ }^{1} \mathrm{H}$ NMR $(400 \mathrm{MHz}$, DMSO- $\left.d_{6}\right) \delta 7.30-7.24(\mathrm{~m}, 2 \mathrm{H}), 7.02-6.95(\mathrm{~m}, 2 \mathrm{H}), 4.33$ (dd, $J=11.3,2.7 \mathrm{~Hz}, 1 \mathrm{H}), 3.95$ (s, 2H), 3.83 (dd, $J=11.3,6.5$ $\mathrm{Hz}, 1 \mathrm{H},), 3.33-3.30(\mathrm{~m}, 1 \mathrm{H}), 2.85(\mathrm{t}, J=4.7 \mathrm{~Hz}, 1 \mathrm{H}), 2.71$ (dd, $J=5.1,2.7 \mathrm{~Hz}, 1 \mathrm{H}) .{ }^{13} \mathrm{C}$ NMR $\left(101 \mathrm{MHz}, \mathrm{DMSO}-d_{6}\right) \delta$ $158.17,129.78,129.78,123.86,119.92,115.41,115.41,69.46$, 50.14, 44.21, 22.04.

2-(2-Fluoro-4-(oxiran-2-ylmethoxy)phenyl)acetonitrile 18. The title compound was prepared according to general procedure (1) from 2-(2-fluoro-4-hydroxyphenyl)acetonitrile $(4.1 \mathrm{~g}, 0.02 \mathrm{~mol})$ as the starting material. White solid $(2 \mathrm{~g}$, $36 \%) .{ }^{1} \mathrm{H}$ NMR (400 MHz, DMSO- $\left.d_{6}\right) \delta 7.37(\mathrm{t}, J=8.8 \mathrm{~Hz}$, $1 \mathrm{H}), 6.96(\mathrm{~d}, J=2.6 \mathrm{~Hz}, 1 \mathrm{H}), 6.86(\mathrm{dd}, J=8.8,2.6 \mathrm{~Hz}, 1 \mathrm{H})$, $4.38(\mathrm{dd}, J=11.5,2.6 \mathrm{~Hz}, 1 \mathrm{H}), 3.96(\mathrm{~s}, 2 \mathrm{H}), 3.86(\mathrm{dd}, J=$ 11.5, $6.6 \mathrm{~Hz}, 1 \mathrm{H}), 3.37-3.30(\mathrm{~m}, 1 \mathrm{H}), 2.90-2.81(\mathrm{~m}, 1 \mathrm{H})$, $2.71(\mathrm{dd}, J=5.1,2.7 \mathrm{~Hz}, 1 \mathrm{H}) .{ }^{13} \mathrm{C}$ NMR (101 MHz, DMSO$\left.d_{6}\right) \delta 161.19(\mathrm{~d}, J=226.9 \mathrm{~Hz}), 159.78(\mathrm{~d}, J=8.7 \mathrm{~Hz}), 131.40$ $(\mathrm{d}, J=5.1 \mathrm{~Hz}), 118.81,111.71(\mathrm{~d}, J=3.6 \mathrm{~Hz}), 110.91(\mathrm{~d}, J=$ $15.3 \mathrm{~Hz}$ ), 102.85 (d, $J=24.5 \mathrm{~Hz}$ ), 69.98, 49.95, 44.18, 16.67 .

2-(3-Fluoro-4-(oxiran-2-ylmethoxy)phenyl)acetonitrile 19. The title compound was prepared according to general procedure (1) using 2-(3-fluoro-4-hydroxyphenyl)acetonitrile $(3.2 \mathrm{~g}, 0.01 \mathrm{~mol})$ as the starting material. White solid $(1.5 \mathrm{~g}$, $35 \%) .{ }^{1} \mathrm{H}$ NMR (400 MHz, DMSO-d 6 ) $\delta 7.27-7.17(\mathrm{~m}, 2 \mathrm{H})$, $7.16-7.10(\mathrm{~m}, 1 \mathrm{H}), 4.42(\mathrm{dd}, J=11.4,2.6 \mathrm{~Hz}, 1 \mathrm{H}), 3.97(\mathrm{~s}$, $2 \mathrm{H}), 3.92(\mathrm{dd}, J=11.4,6.6 \mathrm{~Hz}, 1 \mathrm{H}), 3.43-3.36(\mathrm{~m}, 1 \mathrm{H}), 2.87$ $(\mathrm{h}, J=5.6,5.2 \mathrm{~Hz}, 1 \mathrm{H}), 2.77-2.68(\mathrm{~m}, 1 \mathrm{H}) .{ }^{13} \mathrm{C}$ NMR $(101$ $\left.\mathrm{MHz}, \mathrm{DMSO}-d_{6}\right) \delta 151.91(\mathrm{~d}, J=245.8 \mathrm{~Hz}), 146.01(\mathrm{~d}, J=$ $10.5 \mathrm{~Hz}) 124.95(\mathrm{~d}, J=4.2 \mathrm{~Hz}), 119.56,116.63(\mathrm{~d}, J=21.0$ $\mathrm{Hz}), 116.01$ (d, $J=1.5 \mathrm{~Hz}), 70.65,49.99,44.16,21.91$.

2-((4-Phenoxyphenoxy)methyl)oxirane 21. The title compound was prepared according to general procedure (1) using 4-phenoxyphenol ( $2 \mathrm{~g}, 0.01 \mathrm{~mol})$ as a starting material. White solid (0.6 g, 23\%). ${ }^{1} \mathrm{H}$ NMR (400 MHz, DMSO- $\left.d_{6}\right) \delta 7.32(\mathrm{t}, J$ = 9.6, $8.7 \mathrm{~Hz}, 2 \mathrm{H}), 7.06(\mathrm{t}, J=7.3 \mathrm{~Hz}, 1 \mathrm{H}), 6.99(\mathrm{~d}, J=6.6$, $3.8 \mathrm{~Hz}, 4 \mathrm{H}), 6.92(\mathrm{t}, J=8.7,7.2 \mathrm{~Hz}, 2 \mathrm{H}), 4.27-3.75(\mathrm{~m}, 4 \mathrm{H})$, $3.44(\mathrm{~s}, 1 \mathrm{H}) .{ }^{13} \mathrm{C}$ NMR (101 MHz, DMSO-d $d_{6} \delta$ 158.46, $155.42,150.00,130.32,130.29,123.03,121.15,121.09,117.83$, $117.75,116.34,116.19,68.76,51.11,44.21$.

General Procedure (2) for Preparation of 22-41. To a stirred solution of QZN (2-11) (1 equiv) in $\mathrm{MeCN}$, an epoxide derivative (12-21) (1.2 equiv), $\mathrm{Cs}_{2} \mathrm{CO}_{3}$ (2 equiv), and TBAI ( 0.1 equiv) were added. The reaction mixture was refluxed at $100{ }^{\circ} \mathrm{C}$ for $16 \mathrm{~h}$. The mixture was then filtered, concentrated in vacuo, and purified using column chromatography with EtOAc:PE 80:20 as the eluent.

2-(4-(3-(6-Chloro-4-oxoquinazolin-3(4H)-yl)-2hydroxypropoxy)phenyl)acetonitrile 22 . The title compound was prepared according to general procedure (2) using 2 (7.3 $\mathrm{g}, 0.041 \mathrm{~mol})$ and $12(9.5 \mathrm{~g}, 0.05 \mathrm{~mol})$. Off white solid $(3.2 \mathrm{~g}$, 21\%). ${ }^{1} \mathrm{H}$ NMR (400 MHz, DMSO-d $) ~ \delta 8.32$ (s, 1H), 8.19$8.08(\mathrm{~m}, 1 \mathrm{H}), 7.74(\mathrm{dd}, J=10.6,2.1 \mathrm{~Hz}, 1 \mathrm{H}), 7.58(\mathrm{dd}, J=$ $8.5,2.1 \mathrm{~Hz}, 1 \mathrm{H}), 7.26(\mathrm{~d}, J=8.5 \mathrm{~Hz}, 2 \mathrm{H}), 6.99-6.92(\mathrm{~m}, 2 \mathrm{H})$, $5.51(\mathrm{~d}, J=5.6 \mathrm{~Hz}, 1 \mathrm{H}), 4.33(\mathrm{dd}, J=13.4,3.7 \mathrm{~Hz}, 1 \mathrm{H}), 4.21-$ $4.13(\mathrm{~m}, 1 \mathrm{H}), 4.06-3.90(\mathrm{~m}, 2 \mathrm{H}), 3.94(\mathrm{~s}, 2 \mathrm{H}), 3.92-3.84$ $(\mathrm{m}, 1 \mathrm{H}) .{ }^{13} \mathrm{C}$ NMR $\left(101 \mathrm{MHz}, \mathrm{DMSO}-d_{6}\right) \delta 160.37,158.30$, $150.66,147.46,139.34,129.78,128.66,127.66,126.74,123.78$, 120.93, 119.99, 115.47, 70.73, 66.46, 49.95, 22.01. LCMS calculated for $\mathrm{C}_{19} \mathrm{H}_{17} \mathrm{ClN}_{3} \mathrm{O}_{3}{ }^{+}[\mathrm{M}+\mathrm{H}]^{+}$: 370.1 found 370.3, HRMS calculated for $\mathrm{C}_{19} \mathrm{H}_{17} \mathrm{ClN}_{3} \mathrm{O}_{3}{ }^{+}[\mathrm{M}+\mathrm{H}]^{+}: 370.0953$ found 370.0956 .

2-(4-(3-(7-Chloro-4-oxoquinazolin-3(4H)-yl)-2hydroxypropoxy)phenyl)acetonitrile 23 . The title compound was prepared according to general procedure (2) using 3 (1g, $5.5 \mathrm{mmol})$ and $12(1.25 \mathrm{~g}, 6.6 \mathrm{mmol})$. Off white solid (0.45 g, 24\%). ${ }^{1} \mathrm{H}$ NMR (400 MHz, DMSO-d 6 ) $\delta 8.32$ (s, 1H), 8.15 $(\mathrm{d}, J=7.5 \mathrm{~Hz}, 1 \mathrm{H}), 7.89$ (d, $J=1.9 \mathrm{~Hz}, 1 \mathrm{H}), 7.67$ (dd, $J=7.5$, $1.9 \mathrm{~Hz}, 1 \mathrm{H}), 7.35-7.26(\mathrm{~m}, 2 \mathrm{H}), 7.10-6.97(\mathrm{~m}, 2 \mathrm{H}), 5.51(\mathrm{~d}$, $J=5.0 \mathrm{~Hz}, 1 \mathrm{H}), 4.74-4.65(\mathrm{~m}, 1 \mathrm{H}), 4.25(\mathrm{dd}, J=12.3,1.7$ $\mathrm{Hz}, 1 \mathrm{H}), 4.11$ (dd, $J=12.4,4.9 \mathrm{~Hz}, 1 \mathrm{H}), 3.82$ (dd, $J=12.4$, $9.9 \mathrm{~Hz}, 1 \mathrm{H}), 3.75-3.62(\mathrm{~m}, 2 \mathrm{H}), 3.48(\mathrm{dd}, J=12.4,4.9 \mathrm{~Hz}$, 1H). ${ }^{13} \mathrm{C}$ NMR (101 MHz, DMSO-d $) \delta 160.18,158.57$, 149.72, 138.91, 127.78, 127.12, 124.54, 120.40, 117.53, 115.32, 71.22, 68.18, 51.16, 25.31. LCMS calculated for $\mathrm{C}_{19} \mathrm{H}_{17} \mathrm{ClN}_{3} \mathrm{O}_{3}^{+}[\mathrm{M}+\mathrm{H}]^{+}: 370.1$ found 370.5, HRMS calculated for $\mathrm{C}_{19} \mathrm{H}_{17} \mathrm{ClN}_{3} \mathrm{O}_{3}{ }^{+}\left[\mathrm{M}+\mathrm{H}^{+}\right.$: 370.0953 found 370.0957.

2-(4-(3-(6,7-Dichloro-4-oxoquinazolin-3(4H)-yl)-2hydroxypropoxy)phenyl)acetonitrile 24. The title compound was prepared according to general procedure (2) using 4 (1g, $4.6 \mathrm{mmol}$ ) and 12 (1.05 g, $5.5 \mathrm{mmol})$. Off white solid (0.63 g, 28\%). ${ }^{1} \mathrm{H}$ NMR (400 MHz, DMSO-d 6 ) $\delta 8.30(\mathrm{~s}, 1 \mathrm{H}), 8.19$ (s, $1 \mathrm{H}), 7.66(\mathrm{~s}, 1 \mathrm{H}), 7.30-7.21(\mathrm{~m}, 2 \mathrm{H}), 6.96-6.88(\mathrm{~m}, 2 \mathrm{H})$, $5.59(\mathrm{~d}, J=5.0 \mathrm{~Hz}, 1 \mathrm{H}), 4.71(\mathrm{dqd}, J=10.1,5.0,1.7 \mathrm{~Hz}, 1 \mathrm{H})$, 4.35 (dd, $J=12.3,9.9 \mathrm{~Hz}, 1 \mathrm{H}), 4.17(\mathrm{dd}, J=12.4,5.0 \mathrm{~Hz}$, $1 \mathrm{H}), 3.89$ (dd, $J=12.5,1.7 \mathrm{~Hz}, 1 \mathrm{H}), 3.75-3.62(\mathrm{~m}, 2 \mathrm{H}), 3.50$ $(\mathrm{dd}, J=12.4,5.0 \mathrm{~Hz}, 1 \mathrm{H}) .{ }^{13} \mathrm{C}$ NMR $(101 \mathrm{MHz}$, DMSO-d6) $\delta$ $159.47,158.37,148.88,148.72,129.96,128.36,126.12,116.52$, 115.31, 71.22, 68.18, 50.32, 24.30. LCMS calculated for $\mathrm{C}_{19} \mathrm{H}_{16} \mathrm{Cl}_{2} \mathrm{~N}_{3} \mathrm{O}_{3}^{+}[\mathrm{M}+\mathrm{H}]^{+}: 404.1$ found 404.5

2-(4-(3-(6,8-Dichloro-4-oxoquinazolin-3(4H)-yl)-2hydroxypropoxy)phenyl)acetonitrile 25 . The title compound was prepared according to general procedure (2) using 5 (1g, $4.6 \mathrm{mmol})$ and 12 (1.05 g, $5.5 \mathrm{mmol})$. Off white solid (0.78 g, 35\%). ${ }^{1} \mathrm{H}$ NMR (400 MHz, DMSO-d 6 ) $\delta 8.33(\mathrm{~s}, 1 \mathrm{H}), 8.24$ $(\mathrm{d}, J=1.9 \mathrm{~Hz}, 1 \mathrm{H}), 7.88(\mathrm{~d}, J=2.1 \mathrm{~Hz}, 1 \mathrm{H}), 7.30-7.21(\mathrm{~m}$, $2 \mathrm{H}), 6.95-6.87(\mathrm{~m}, 2 \mathrm{H}), 5.18(\mathrm{~d}, J=5.1 \mathrm{~Hz}, 1 \mathrm{H}), 4.64-4.73$ $(\mathrm{m}, 1 \mathrm{H}), 4.24(\mathrm{dd}, J=12.3,9.6 \mathrm{~Hz}, 1 \mathrm{H}), 4.05(\mathrm{dd}, J=12.3$, $5.0 \mathrm{~Hz}, 1 \mathrm{H}), 3.83(\mathrm{dd}, J=12.3,1.7 \mathrm{~Hz}, 1 \mathrm{H}), 3.75-3.62(\mathrm{~m}$, $2 \mathrm{H}), 3.49(\mathrm{~m}, 1 \mathrm{H}) .{ }^{13} \mathrm{C}$ NMR $\left(101 \mathrm{MHz}, \mathrm{DMSO}-d_{6}\right) \delta$ $160.39,157.57,150.26,149.46,133.92,133.38,128.34,126.74$, $126.32,126.12,124.86,117.52,115.32,71.32,67.18,50.16$, 24.30. LCMS calculated for $\mathrm{C}_{19} \mathrm{H}_{16} \mathrm{Cl}_{2} \mathrm{~N}_{3} \mathrm{O}_{3}{ }^{+}[\mathrm{M}+\mathrm{H}]^{+}: 404.1$ found 404.7

2-(4-(3-(5-Chloro-4-oxoquinazolin-3(4H)-yl)-2hydroxypropoxy)phenyl)acetonitrile 26 . The title compound was prepared according to general procedure (2) using 6 (1g, $5.5 \mathrm{mmol})$ and $12(1.25 \mathrm{~g}, 6.6 \mathrm{mmol})$. Off white solid (0.84 g, $41 \%) .{ }^{1} \mathrm{H}$ NMR (400 MHz, DMSO-d 6 ) $\delta 8.30$ (s, 1H), 7.77$7.66(\mathrm{~m}, 2 \mathrm{H}), 7.65(\mathrm{dd}, J=6.5,2.7 \mathrm{~Hz}, 1 \mathrm{H}), 7.27-7.21(\mathrm{~m}$, $2 \mathrm{H}), 6.95-6.87(\mathrm{~m}, 2 \mathrm{H}), 5.04(\mathrm{~d}, J=5.1 \mathrm{~Hz}, 1 \mathrm{H}), 4.794 .73$ $(\mathrm{m}, 1 \mathrm{H}), 4.27(\mathrm{dd}, J=12.3,1.8 \mathrm{~Hz}, 1 \mathrm{H}), 4.12$ (dd, $J=12.4$, $4.9 \mathrm{~Hz}, 1 \mathrm{H}), 3.81$ (dd, $J=12.3,9.3 \mathrm{~Hz}, 1 \mathrm{H}), 3.74-3.62(\mathrm{~m}$, $2 \mathrm{H}), 3.47(\mathrm{~m}, 1 \mathrm{H}) .{ }^{13} \mathrm{C}$ NMR (101 MHz, DMSO-d $d_{6} \delta$ $158.57,157.77,147.27,142.87,134.82,129.99,127.74,126.51$, 126.12 , 122.56, 118.98, 117.52, 115.32, 70.22, 67.18, 51.16, 24.25. LCMS calculated for $\mathrm{C}_{19} \mathrm{H}_{17} \mathrm{ClN}_{3} \mathrm{O}_{3}{ }^{+}[\mathrm{M}+\mathrm{H}]^{+}: 370.1$ found 370.3

2-(4-(3-(8-Chloro-4-oxoquinazolin-3(4H)-yl)-2hydroxypropoxy)phenyl)acetonitrile 27 . The title compound was prepared according to general procedure (2) using 7 (1g, 
$5.5 \mathrm{mmol})$ and $12(1.25 \mathrm{~g}, 6.6 \mathrm{mmol})$. Off white solid $(0.64 \mathrm{~g}$, 29\%). ${ }^{1} \mathrm{H}$ NMR (400 MHz, DMSO- $\left.d_{6}\right) \delta 8.32$ (s, $\left.1 \mathrm{H}\right), 8.26-$ $8.17(\mathrm{~m}, 1 \mathrm{H}), 7.76(\mathrm{dd}, J=7.5,2.1 \mathrm{~Hz}, 1 \mathrm{H}), 7.65(\mathrm{t}, J=7.4$ $\mathrm{Hz}, 1 \mathrm{H}), 7.30-7.21(\mathrm{~m}, 2 \mathrm{H}), 6.96-6.88(\mathrm{~m}, 2 \mathrm{H}), 5.17$ (d, $J=$ $5.0 \mathrm{~Hz}, 1 \mathrm{H}), 4.78-4.69(\mathrm{~m}, 1 \mathrm{H}), 4.24(\mathrm{dd}, J=12.5,1.7 \mathrm{~Hz}$, $1 \mathrm{H}), 4.09$ (dd, $J=12.5,4.9 \mathrm{~Hz}, 1 \mathrm{H}), 3.84(\mathrm{dd}, J=12.5,9.9$ $\mathrm{Hz}, 1 \mathrm{H}), 3.75-3.62(\mathrm{~m}, 2 \mathrm{H}), 3.54-3.47(\mathrm{~m}, 1 \mathrm{H}) .{ }^{13} \mathrm{C} \mathrm{NMR}$ $\left(101 \mathrm{MHz}, \mathrm{DMSO}-d_{6}\right) \delta 158.96,158=7.57,147.46,147.41$, $131.40,127.74,126.53,125.37,122.75,116.52,115.31,70.22$, 67.18, 50.16, 24.35. LCMS calculated for $\mathrm{C}_{19} \mathrm{H}_{17} \mathrm{ClN}_{3} \mathrm{O}_{3}{ }^{+}[\mathrm{M}$ $+\mathrm{H}]^{+}: 370.1$ found 370.4

2-(4-(2-Hydroxy-3-(6-nitro-4-oxoquinazolin-3(4H)-yl)propoxy)phenyl)acetonitrile 29. The title compound was prepared according to general procedure (2) using 8 (1g, 5.2 mmol) and 12 (1.19 g, $6.3 \mathrm{mmol})$. Yellow solid (1.1 g, 59\%). ${ }^{1} \mathrm{H}$ NMR (400 MHz, DMSO-d $\left.)_{6}\right) \delta .75(\mathrm{~d}, J=1.9 \mathrm{~Hz}, 1 \mathrm{H})$, 8.65-8.56 (m, 2H), $7.96(\mathrm{~d}, J=7.5 \mathrm{~Hz}, 1 \mathrm{H}), 7.30-7.21(\mathrm{~m}$, $2 \mathrm{H}), 6.96-6.88(\mathrm{~m}, 2 \mathrm{H}), 5.08(\mathrm{~d}, J=5.0 \mathrm{~Hz}, 1 \mathrm{H}), 4.71$ (ddd $J$ $=9.9,5.0,1.7 \mathrm{~Hz}, 1 \mathrm{H}), 4.24(\mathrm{dd}, J=12.5,1.7 \mathrm{~Hz}, 1 \mathrm{H}), 4.17$ (dd, $J=12.4,4.9 \mathrm{~Hz}, 1 \mathrm{H}), 3.89$ (dd, $J=12.3,9.9 \mathrm{~Hz}, 1 \mathrm{H})$, $3.75-3.62(\mathrm{~m}, 2 \mathrm{H}), 3.54-3.48(\mathrm{~m}, 1 \mathrm{H}) .{ }^{13} \mathrm{C} \mathrm{NMR}(101 \mathrm{MHz}$, DMSO- $\left.d_{6}\right) \delta 159.69,158.56,149.44,148.14,143.16,127.78$, $127.33,126.50,125.42,117.52,113.32,71.22,68.18,51.16$, 24.30. LCMS calculated for $\mathrm{C}_{19} \mathrm{H}_{16} \mathrm{~N}_{4} \mathrm{O}_{5}{ }^{+}[\mathrm{M}+\mathrm{H}]^{+}: 381.1$ found 380.2, HRMS calculated for $\mathrm{C}_{19} \mathrm{H}_{16} \mathrm{~N}_{4} \mathrm{O}_{5}{ }^{+}[\mathrm{M}+\mathrm{H}]^{+}$: 381.1193 found 380.1198

2-(4-(2-Hydroxy-3-(7-nitro-4-oxoquinazolin-3(4H)-yl)propoxy)phenyl)acetonitrile 30 . The title compound was prepared according to general procedure (2) using 9 (1g, 5.2 $\mathrm{mmol}$ ) and 12 (1.19 g, $6.3 \mathrm{mmol}$ ). Yellow solid (1.3 g, 65\%). ${ }^{1} \mathrm{H}$ NMR (400 MHz, DMSO- $\left.d_{6}\right) \delta 8.52(\mathrm{~s}, 1 \mathrm{H}), 8.42(\mathrm{~d}, J=$ $1.7 \mathrm{~Hz}, 1 \mathrm{H}), 8.32-8.23(\mathrm{~m}, 2 \mathrm{H}), 7.30-7.21(\mathrm{~m}, 2 \mathrm{H}), 6.96-$ $6.87(\mathrm{~m}, 2 \mathrm{H}), 5.08(\mathrm{~d}, J=5.0 \mathrm{~Hz}, 1 \mathrm{H}), 4.69-4.58(\mathrm{~m}, 1 \mathrm{H})$, $4.23(\mathrm{dd}, J=12.5,1.7 \mathrm{~Hz}, 1 \mathrm{H}), 4.09$ (dd, $J=12.4,4.9 \mathrm{~Hz}$, $1 \mathrm{H}), 3.86-3.83(\mathrm{~m}, 1 \mathrm{H}), 3.75-3.62(\mathrm{~m}, 2 \mathrm{H}), 3.50(\mathrm{dd}, J=$ $12.5,4.9 \mathrm{~Hz}, 1 \mathrm{H}) .{ }^{13} \mathrm{C}$ NMR $\left(101 \mathrm{MHz}, \mathrm{DMSO}-d_{6}\right) \delta 159.97$, $157.57,148.43,148.34,147.16,126.74,126.33,126.15,125.42$, 117.52, 115.32, 70.22, 67.18, 53.18, 24.19. LCMS calculated for $\mathrm{C}_{19} \mathrm{H}_{16} \mathrm{~N}_{4} \mathrm{O}_{5}^{+}[\mathrm{M}+\mathrm{H}]^{+}$: 381.1 found 380.2

2-(4-(2-Hydroxy-3-(4-oxo-6-(trifluoromethyl)quinazolin$3(4 H)-y l)$ propoxy)phenyl)acetonitrile 31 . The title compound was prepared according to general procedure (2) using 10 (1g, $4.7 \mathrm{mmol}$ ) and $12(1.06 \mathrm{~g}, 5.6 \mathrm{mmol})$. Yellow solid $(0.9 \mathrm{~g}$, $48 \%) .{ }^{1} \mathrm{H}$ NMR (400 MHz, DMSO-d $) \delta 8.62$ (s, 1H), 8.49$8.43(\mathrm{~m}, 1 \mathrm{H}), 8.13-7.91(\mathrm{~m}, 1 \mathrm{H}), 7.74(\mathrm{~d}, J=7.5 \mathrm{~Hz}, 1 \mathrm{H})$, $7.28-7.23(\mathrm{~m}, 1 \mathrm{H}), 6.96-6.88(\mathrm{~m}, 2 \mathrm{H}), 4.97(\mathrm{~d}, J=5.1 \mathrm{~Hz}$, $1 \mathrm{H}), 4.81$ (ddd, $J=9.9,5.0,1.7 \mathrm{~Hz}, 1 \mathrm{H}), 4.24$ (dd, $J=12.3$, $1.7 \mathrm{~Hz}, 1 \mathrm{H}), 4.12(\mathrm{dd}, J=12.3,4.9 \mathrm{~Hz}, 1 \mathrm{H}), 3.84(\mathrm{dd}, J=$ $12.4,9.9 \mathrm{~Hz}, 1 \mathrm{H}), 3.74-3.62(\mathrm{~m}, 2 \mathrm{H}), 3.49$ (dd, $J=12.4,4.9$ $\mathrm{Hz}, 1 \mathrm{H}) .{ }^{13} \mathrm{C}$ NMR $\left(101 \mathrm{MHz}, \mathrm{DMSO}-d_{6}\right) \delta 159.67,157.57$, 157.12 , 148.43, 128.92, 128.40, 128.28, 127.74, 126.38, 126.28, $126.12,124.78,122.31,117.63,114.52,112.31,71.22,67.18$, 52.16, 23.95. LCMS calculated for $\mathrm{C}_{20} \mathrm{H}_{16} \mathrm{~F}_{3} \mathrm{~N}_{3} \mathrm{O}_{3}{ }^{+}[\mathrm{M}+\mathrm{H}]^{+}$: 404.1 found 403.0, HRMS calculated for $\mathrm{C}_{20} \mathrm{H}_{16} \mathrm{~F}_{3} \mathrm{~N}_{3} \mathrm{O}_{3}{ }^{+}[\mathrm{M}+$ $\mathrm{H}]^{+}: 404.1217$ found 404.1214 .

2-(4-(3-(6-Chloro-2-methyl-4-oxoquinazolin-3(4H)-yl)-2hydroxypropoxy)phenyl)acetonitrile 32. The title compound was prepared according to general procedure (2) using 11 (1g, $5.2 \mathrm{mmol}$ ) and $23(1.17 \mathrm{~g}, 6.2 \mathrm{mmol})$. White solid (1.3 g, $65 \%) .{ }^{1} \mathrm{H}$ NMR (400 MHz, DMSO- $\left.d_{6}\right) \delta 8.03(\mathrm{~d}, J=2.5 \mathrm{~Hz}$, $1 \mathrm{H}), 7.81(\mathrm{dd}, J=8.7,2.5 \mathrm{~Hz}, 1 \mathrm{H}), 7.62(\mathrm{~d}, J=8.7 \mathrm{~Hz}, 1 \mathrm{H})$, $7.32-7.22(\mathrm{~m}, 2 \mathrm{H}), 7.02-6.92(\mathrm{~m}, 2 \mathrm{H}), 5.51(\mathrm{~d}, J=5.3 \mathrm{~Hz}$, $1 \mathrm{H}$ ), 4.37 (dd, $J=13.9,3.6 \mathrm{~Hz}, 1 \mathrm{H}), 4.24$ (ddd, $J=9.2$, 5.5,
$4.0 \mathrm{~Hz}, 1 \mathrm{H}), 4.11-3.98(\mathrm{~m}, 3 \mathrm{H}), 3.95$ (s, 2H), 2.68 (s, 3H). ${ }^{13} \mathrm{C}$ NMR (101 MHz, DMSO-d $\left.d_{6}\right) \delta 160.95,158.35,157.21$, $146.37,134.81,130.71,129.77,129.27,125.46,123.73,121.75$, 119.99, 115.48, 70.94, 66.59, 39.68, 24.12, 22.02. LCMS calculated for $\mathrm{C}_{20} \mathrm{H}_{19} \mathrm{ClN}_{3} \mathrm{O}_{3}{ }^{+}[\mathrm{M}+\mathrm{H}]^{+}: 384.1$ found 384.8, HRMS calculated for $\mathrm{C}_{20} \mathrm{H}_{19} \mathrm{ClN}_{3} \mathrm{O}_{3}{ }^{+}[\mathrm{M}+\mathrm{H}]^{+}: 384.1110$ found 384.1109 .

2-(3-(3-(6-Chloro-4-oxoquinazolin-3(4H)-yl)-2hydroxypropoxy)phenyl)acetonitrile 33 . The title compound was prepared according to general procedure (2) using 2 ( $1 \mathrm{~g}$, $5.5 \mathrm{mmol})$ and $13(1.26 \mathrm{~g}, 6.6 \mathrm{mmol})$. Off white solid $(1.4 \mathrm{~g}$, 69\%). ${ }^{1} \mathrm{H}$ NMR (400 MHz, DMSO- $\left.d_{6}\right) \delta 8.32(\mathrm{~s}, 1 \mathrm{H}), 8.23$ $(\mathrm{d}, J=2.0 \mathrm{~Hz}, 1 \mathrm{H}), 7.72(\mathrm{dd}, J=7.5,1.9 \mathrm{~Hz}, 1 \mathrm{H}), 7.39-7.27$ $(\mathrm{m}, 1 \mathrm{H}), 7.07(\mathrm{t}, J=7.4 \mathrm{~Hz}, 1 \mathrm{H}), 7.01-6.87(\mathrm{~m}, 3 \mathrm{H}), 5.12(\mathrm{~d}$, $J=5.0 \mathrm{~Hz}, 1 \mathrm{H}), 4.61(\mathrm{ddd}, J=9.9,5.0,1.9 \mathrm{~Hz}, 1 \mathrm{H}), 4.22(\mathrm{dd}$, $J=12.4,1.8 \mathrm{~Hz}, 1 \mathrm{H}), 4.10$ (dd, $J=12.4,4.9 \mathrm{~Hz}, 1 \mathrm{H}), 3.94-$ $3.81(\mathrm{~m}, 2 \mathrm{H}), 3.77-3.72(\mathrm{~m}, 1 \mathrm{H}), 3.49(\mathrm{dd}, J=12.3,4.9 \mathrm{~Hz}$, $1 \mathrm{H}) .{ }^{13} \mathrm{C}$ NMR (101 MHz, DMSO- $\left.d_{6}\right) \delta 159.06,157.99$, $152.16,149.43,132.59,128.09,126.11,125.59,125.50,123.69$, 114.52, 113.80, 112.42, 71.34, 67.18, 50.16, 24.86.

4-(3-(6-Chloro-4-oxoquinazolin-3(4H)-yl)-2hydroxypropoxy)benzonitrile 34 . The title compound was prepared according to general procedure (2) using 2 (1g, 5.5 $\mathrm{mmol})$ and 14 (1.15 g, $6.6 \mathrm{mmol})$. Off white solid $(0.95 \mathrm{~g}$, 48\%). ${ }^{1} \mathrm{H}$ NMR (400 MHz, DMSO-d 6 ) $\delta 8.29$ (s, 1H), 8.09 $(\mathrm{d}, J=2.5 \mathrm{~Hz}, 1 \mathrm{H}), 7.90-7.78(\mathrm{~m}, 3 \mathrm{H}), 7.71(\mathrm{~d}, J=8.7 \mathrm{~Hz}$, $1 \mathrm{H}), 7.54$ (d, $J=8.3 \mathrm{~Hz}, 2 \mathrm{H}), 5.33$ (d, $J=5.7 \mathrm{~Hz}, 1 \mathrm{H}), 4.62$ (s, $2 \mathrm{H}), 4.28(\mathrm{dd}, J=13.4,3.6 \mathrm{~Hz}, 1 \mathrm{H}), 3.82(\mathrm{dd}, J=13.4,8.6$ $\mathrm{Hz}, 1 \mathrm{H}) .{ }^{13} \mathrm{C}$ NMR $\left(101 \mathrm{MHz}, \mathrm{DMSO}-d_{6}\right) \delta 159.93,149.70$, $147.22,144.74,134.81,132.65,131.60,129.89,128.31,125.45$, $123.30,119.32,110.53,71.87,66.97,50.17$. LCMS calculated for $\mathrm{C}_{18} \mathrm{H}_{15} \mathrm{ClN}_{3} \mathrm{O}_{3}^{+}[\mathrm{M}+\mathrm{H}]^{+}$: 356.1 found 356.6.

3-(3-(6-Chloro-4-oxoquinazolin-3(4H)-yl)-2hydroxypropoxy)benzonitrile 35 . The title compound was prepared according to general procedure (2) using 2 (1g, 5.5 $\mathrm{mmol})$ and 15 (1.15 g, $6.6 \mathrm{mmol})$. Off white solid (1.1 g, 56\%). ${ }^{1} \mathrm{H}$ NMR (400 MHz, DMSO-d 6 ) $\delta 8.31(\mathrm{~s}, 1 \mathrm{H}), 8.12$ $(\mathrm{d}, J=2.5 \mathrm{~Hz}, 1 \mathrm{H}), 7.90-7.78(\mathrm{~m}, 3 \mathrm{H}), 7.69(\mathrm{~m}, 1 \mathrm{H}), 7.57$ (d, $J=8.3 \mathrm{~Hz}, 2 \mathrm{H}), 5.33(\mathrm{~d}, J=5.7 \mathrm{~Hz}, 1 \mathrm{H}), 4.62(\mathrm{~s}, 2 \mathrm{H})$, $4.28(\mathrm{dd}, J=13.4,3.6 \mathrm{~Hz}, 1 \mathrm{H}), 3.82(\mathrm{dd}, J=13.4,8.6 \mathrm{~Hz}$, $1 \mathrm{H}) .{ }^{13} \mathrm{C}$ NMR (101 MHz, DMSO- $\left.d_{6}\right) \delta 159.68,159.48$, 151.16, 148.43, 129.12, 127.11, 126.59, 126.50, 123.78, 120.61, $118.49,110.75,70.22,67.18,50.16$. LCMS calculated for $\mathrm{C}_{18} \mathrm{H}_{15} \mathrm{ClN}_{3} \mathrm{O}_{3}^{+}[\mathrm{M}+\mathrm{H}]^{+}$: 356.1 found 356.2.

3-(4-(3-(6-Chloro-4-oxoquinazolin-3(4H)-yl)-2hydroxypropoxy)phenyl)propanenitrile 36 . The title compound was prepared according to general procedure (2) using $2(1 \mathrm{~g}, 5.5 \mathrm{mmol})$ and $16(1.3 \mathrm{~g}, 6.6 \mathrm{mmol})$. Off white solid (1.7 g, 80\%). ${ }^{1} \mathrm{H}$ NMR (400 MHz, DMSO- $\left.d_{6}\right) \delta 8.30(\mathrm{~s}, 1 \mathrm{H})$, $8.09(\mathrm{~d}, J=2.5 \mathrm{~Hz}, 1 \mathrm{H}), 7.86(\mathrm{dd}, J=8.7,2.5 \mathrm{~Hz}, 1 \mathrm{H}), 7.71$ $(\mathrm{d}, J=8.7 \mathrm{~Hz}, 1 \mathrm{H}), 7.24-7.15(\mathrm{~m}, 2 \mathrm{H}), 6.93-6.84(\mathrm{~m}, 2 \mathrm{H})$, $5.48(\mathrm{~d}, J=5.7 \mathrm{~Hz}, 1 \mathrm{H}), 4.33(\mathrm{dd}, J=13.4,3.7 \mathrm{~Hz}, 1 \mathrm{H}), 4.16$ $(\mathrm{tt}, J=8.9,5.2 \mathrm{~Hz}, 1 \mathrm{H}), 3.97(\mathrm{dt}, J=7.0,3.2 \mathrm{~Hz}, 2 \mathrm{H}), 3.89$ $(\mathrm{dd}, J=13.4,8.6 \mathrm{~Hz}, 1 \mathrm{H}), 2.85-2.70(\mathrm{~m}, 4 \mathrm{H}) .{ }^{13} \mathrm{C} \mathrm{NMR}(101$ $\left.\mathrm{MHz}, \mathrm{DMSO}-d_{6}\right) \delta 159.97,157.72,149.72,147.23,134.86$, $131.63,131.58,129.97,129.91,125.49,123.34,120.75,115.01$, $70.69,66.50,50.07,30.22,18.95$. LCMS calculated for $\mathrm{C}_{20} \mathrm{H}_{19} \mathrm{ClN}_{3} \mathrm{O}_{3}{ }^{+}[\mathrm{M}+\mathrm{H}]^{+}$: 384.1 found 383.9, HRMS calculated for $\mathrm{C}_{20} \mathrm{H}_{19} \mathrm{ClN}_{3} \mathrm{O}_{3}{ }^{+}[\mathrm{M}+\mathrm{H}]^{+}$: 384.1109 found 384.1116 .

1-(4-(3-(6-Chloro-4-oxoquinazolin-3(4H)-yl)-2hydroxypropoxy)phenyl)cyclopropane-1-carbonitrile 37. The title compound was prepared according to general 
procedure (2) using $2(1 \mathrm{~g}, 5.5 \mathrm{mmol})$ and 17 (1.4 g, 6.6 mmol). Off white solid (1.1 g, 53\%). ${ }^{1} \mathrm{H}$ NMR (400 MHz, Methanol- $\left.d_{4}\right) \delta 8.29(\mathrm{~s}, 1 \mathrm{H}), 8.16(\mathrm{~s}, 1 \mathrm{H}), 7.86-7.63(\mathrm{~m}, 2 \mathrm{H})$, 7.29-7.21 (m, 2H), $6.94(\mathrm{~m}, 2 \mathrm{H}), 4.47(\mathrm{dd}, J=13.6,3.7 \mathrm{~Hz}$, $1 \mathrm{H}), 4.31(\mathrm{dq}, J=8.8,4.7 \mathrm{~Hz}, 1 \mathrm{H}), 4.03(\mathrm{~m}, 3 \mathrm{H}), 1.63(\mathrm{~m}$, $2 \mathrm{H}), 1.38(\mathrm{~m}, 2 \mathrm{H}) .{ }^{13} \mathrm{C}$ NMR (100 MHz, methanol- $\left.d_{4}\right)$ $160.48,158.28$, 148.92, 145.38, 134.71, 132.63, 128.57, 127.33, 125.28, 125.08, 114.72, 70.38, 66.85, 49.75, 16.62, 16.57, 12.67. LCMS calculated for $\mathrm{C}_{21} \mathrm{H}_{19} \mathrm{ClN}_{3} \mathrm{O}_{3}{ }^{+}[\mathrm{M}+\mathrm{H}]^{+}: 396.1$ found 396.4.

4-(3-(6-Chloro-4-oxoquinazolin-3(4H)-yl)-2-hydroxypropoxy)-2-fluorophenyl)acetonitrile 38. The title compound was prepared according to general procedure (2) using 2 (0.15 g, $0.8 \mathrm{mmol})$ and $18(0.2 \mathrm{~g}, 1 \mathrm{mmol})$. White solid $(93 \mathrm{mg}$, 25\%). ${ }^{1} \mathrm{H}$ NMR (400 MHz, DMSO- $d_{6}$ ) $\delta 8.31(\mathrm{~s}, 1 \mathrm{H}), 8.11$ (d, $J=2.4 \mathrm{~Hz}, 1 \mathrm{H}), 7.87(\mathrm{dd}, J=8.7,2.4 \mathrm{~Hz}, 1 \mathrm{H}), 7.72(\mathrm{~d}, J=$ $8.7 \mathrm{~Hz}, 1 \mathrm{H}), 7.36(\mathrm{t}, J=8.8 \mathrm{~Hz}, 1 \mathrm{H}), 6.95-6.88(\mathrm{~m}, 1 \mathrm{H}), 6.83$ (dd, $J=8.5,2.5 \mathrm{~Hz}, 1 \mathrm{H}), 5.54(\mathrm{~d}, J=5.6 \mathrm{~Hz}, 1 \mathrm{H}, \mathrm{OH}), 4.32$ (dd, $J=13.4,3.6 \mathrm{~Hz}, 1 \mathrm{H}), 4.18(\mathrm{ddt}, J=13.9,9.1,5.6 \mathrm{~Hz}$, $1 \mathrm{H}), 4.13-3.99(\mathrm{~m}, 2 \mathrm{H}), 3.99-3.88(\mathrm{~m}, 3 \mathrm{H}) .{ }^{13} \mathrm{C}$ NMR (101 MHz, DMSO- $\left.d_{6}\right) \delta 161.18(\mathrm{~d}, J=226.9 \mathrm{~Hz}), 159.98,159.78$ $(\mathrm{d}, J=8.7 \mathrm{~Hz}), 149.69,147.22,134.88,131.40(\mathrm{~d}, J=5.1 \mathrm{~Hz})$, $129.91,125.31,123.34,118.83,111.79$ (d, $J=3.6 \mathrm{~Hz}), 110.91$ (d, $J=15.3 \mathrm{~Hz}$ ), 102.85 (d, $J=24.5 \mathrm{~Hz}$ ), 71.13, 66.33, 49.90, 16.64. LCMS $m / z$ calc for $\mathrm{C}_{19} \mathrm{H}_{15} \mathrm{ClFN}_{3} \mathrm{O}_{3}{ }^{+}[\mathrm{M}+\mathrm{H}]^{+}$: 388.0, found 388.3 .

2-(4-(3-(6-Chloro-4-oxoquinazolin-3(4H)-yl)-2-hydroxypropoxy)-3-fluorophenyl)acetonitrile 39. The title compound was prepared according to general procedure (2) using 2 (0.13 g, $0.7 \mathrm{mmol})$ and $19(0.18 \mathrm{~g}, 0.8 \mathrm{mmol})$. White solid $(90 \mathrm{mg}$, 24\%). ${ }^{1} \mathrm{H}$ NMR (400 MHz, DMSO-d $) \delta 8.31(\mathrm{~s}, 1 \mathrm{H}), 8.15-$ $8.05(\mathrm{~m}, 1 \mathrm{H}), 7.87$ (ddd, $J=9.0,6.5,2.5 \mathrm{~Hz}, 1 \mathrm{H}), 7.72(\mathrm{dd}, J$ $=9.0,6.5 \mathrm{~Hz}, 1 \mathrm{H}), 7.27-7.19(\mathrm{~m}, 2 \mathrm{H}), 7.14(\mathrm{dd}, J=9.0,1.9$ $\mathrm{Hz}, 1 \mathrm{H}), 5.56(\mathrm{~d}, J=5.6 \mathrm{~Hz}, 1 \mathrm{H}), 4.34(\mathrm{dd}, J=13.4,3.7 \mathrm{~Hz}$, $1 \mathrm{H}), 4.21(\mathrm{~d}, J=10.3 \mathrm{~Hz}, 1 \mathrm{H}), 4.10(\mathrm{dd}, J=5.6,2.6 \mathrm{~Hz}, 2 \mathrm{H})$, 3.98 (s, 2H), 3.92 (dd, $J=13.4,8.5 \mathrm{~Hz}, 1 \mathrm{H}) .{ }^{13} \mathrm{C}$ NMR $(101$ $\left.\mathrm{MHz}, \mathrm{DMSO}-d_{6}\right) \delta 160.00,154(\mathrm{~d}, J=247.3 \mathrm{~Hz}), 147.24$, $146.44,134.93(\mathrm{~d}, J=10.2 \mathrm{~Hz}), 131.62(\mathrm{~d}, J=2.7 \mathrm{~Hz})$, 129.91(d, $J=19.7 \mathrm{~Hz}), 125.31$ (d, $J=1.5 \mathrm{~Hz}), 124.36,123.35$, $119.58,116.49,116.04,72.12,66.42,50.12,21.91$. LCMS $m / z$ calc for $\mathrm{C}_{19} \mathrm{H}_{15} \mathrm{ClFN}_{3} \mathrm{O}_{3}^{+}[\mathrm{M}+\mathrm{H}]^{+}: 388.0$, found 388.3

2-(4-(3-(6-Chloro-4-oxoquinazolin-3(4H)-yl)-2hydroxypropoxy)phenoxy)acetonitrile 40. The title compound was prepared according to general procedure (2) using $2(0.44 \mathrm{~g}, 2.4 \mathrm{mmol})$ and $20(0.6 \mathrm{~g}, 2.9 \mathrm{mmol})$. White solid (0.3 g, 26\%). ${ }^{1} \mathrm{H}$ NMR (400 MHz, DMSO- $\left.d_{6}\right) \delta 8.32(\mathrm{~s}$, $1 \mathrm{H}), 8.10$ (d, $J=2.5 \mathrm{~Hz}, 1 \mathrm{H}), 7.85$ (dd, $J=8.7,2.5 \mathrm{~Hz}, 1 \mathrm{H})$, $7.71(\mathrm{~d}, J=8.7 \mathrm{~Hz}, 1 \mathrm{H}), 7.07-6.97(\mathrm{~m}, 2 \mathrm{H}), 7.00-6.91(\mathrm{~m}$, $2 \mathrm{H}), 5.51(\mathrm{~d}, J=5.6 \mathrm{~Hz}, 1 \mathrm{H}), 5.10(\mathrm{~s}, 2 \mathrm{H}), 4.40-4.31(\mathrm{~m}$, $1 \mathrm{H}), 4.23-4.12(\mathrm{~m}, 1 \mathrm{H}), 3.99$ (dd, $J=5.6,1.8 \mathrm{~Hz}, 2 \mathrm{H}), 3.91$ (dd, $J=13.5,8.6 \mathrm{~Hz}, 1 \mathrm{H}) .{ }^{13} \mathrm{C}$ NMR $\left(101 \mathrm{MHz}, \mathrm{DMSO}-d_{6}\right) \delta$ $159.97,154.34,150.96,149.68,147.19,134.82,131.64,129.86$, $125.48,123.30,117.28,116.68,116.68,116.10,116.10,71.17$, $66.53,54.69,50.06$. LCMS $m / z$ calc for $\mathrm{C}_{19} \mathrm{H}_{16} \mathrm{ClN}_{3} \mathrm{O}_{4}{ }^{+}[\mathrm{M}+$ $\mathrm{H}]^{+}$: 386.0 , found 386.4 .

6-Chloro-3-(2-hydroxy-3-(4-phenoxyphenoxy)propyl)quinazolin-4(3H)-one 41. The title compound was prepared according to general procedure (2) using 2 ( $0.36 \mathrm{~g}, 2 \mathrm{mmol})$ and 21 ( $0.6 \mathrm{~g}, 2.4 \mathrm{mmol})$ as the starting material. White solid (85 mg, 24\%). ${ }^{1} \mathrm{H}$ NMR (400 MHz, DMSO- $d_{6}$ ) $\delta 8.33(\mathrm{~s}$, $1 \mathrm{H}), 8.11$ (d, $J=2.5 \mathrm{~Hz}, 1 \mathrm{H}), 7.88(\mathrm{dd}, J=8.7,2.5 \mathrm{~Hz}, 1 \mathrm{H})$, $7.73(\mathrm{~d}, J=8.7 \mathrm{~Hz}, 1 \mathrm{H}), 7.35(\mathrm{t}, J=9.7,6.0,2.3 \mathrm{~Hz}, 2 \mathrm{H}), 7.08$ $(\mathrm{t}, J=7.4 \mathrm{~Hz}, 1 \mathrm{H}), 6.99(\mathrm{~d}, J=1.7 \mathrm{~Hz}, 4 \mathrm{H}), 6.95-6.90(\mathrm{~m}$,
$2 \mathrm{H}), 5.51(\mathrm{~d}, J=5.6 \mathrm{~Hz}, 1 \mathrm{H}), 4.35(\mathrm{dd}, J=13.4,3.7 \mathrm{~Hz}, 1 \mathrm{H})$, 4.23-4.14 (m, 1H), 4.08-3.97 (m, 2H), 3.92 (dd, $J=13.4,8.6$ $\mathrm{Hz}, 1 \mathrm{H}) .{ }^{13} \mathrm{C}$ NMR (101 MHz, DMSO-d $) \delta 159.99,158.40$, $155.23,150.12$, 149.75, 147.24, 134.88, 131.64, 130.37, 129.92, $125.49,123.34,123.11,121.22,121.12,118.01,117.84,116.33$, $116.20,115.96,71.11,66.50,50.05$. LCMS $\mathrm{m} / z$ calc for $\mathrm{C}_{23} \mathrm{H}_{19} \mathrm{ClN}_{2} \mathrm{O}_{4}^{+}[\mathrm{M}+\mathrm{H}]^{+}:$423.1, found 423.4.

Preparation of 2-(4-(2-Amino-3-(6-chloro-4-oxoquinazolin-3(4H)-yl)propoxy)phenyl)acetonitrile 42. To a stirred solution of $22(2 \mathrm{~g}, 5 \mathrm{mmol})$ in anhydrous THF $(100 \mathrm{~mL})$, $\mathrm{Ph}_{3} \mathrm{P}(2 \mathrm{~g}, 8 \mathrm{mmol})$ was added at rt. After $5 \mathrm{~min}$, the mixture was cooled over ice bath before addition of DIAD (1.6 g, 8 mmol) which is followed by DPPA $(2.2 \mathrm{~g}, 8 \mathrm{mmol})$. The mixture was stirred for $5 \mathrm{~min}$ in ice bath, in addition to another $5 \mathrm{~min}$ at rt. This mixture was then allowed to stir at $45{ }^{\circ} \mathrm{C}$ overnight. The reaction mixture was then reduced and purified using column chromatography eluting the desired compound with 40:60 EtOAc:PE. Yellow solid (1 g, 33\%). ${ }^{1} \mathrm{H}$ NMR (400 $\left.\mathrm{MHz}, \mathrm{DMSO}-d_{6}\right) \delta 8.40(\mathrm{~s}, 1 \mathrm{H}), 8.14(\mathrm{~d}, J=2.5 \mathrm{~Hz}, 1 \mathrm{H}), 7.91$ (dd, $J=8.8,2.5 \mathrm{~Hz}, 1 \mathrm{H}), 7.76(\mathrm{~d}, J=8.8, \mathrm{~Hz}, 1 \mathrm{H}), 7.35-7.26$ (m, 2H), 7.13-6.96 (m, 2H), 4.49-4.28 (m, 3H), 4.22-4.10 (m, 2H), $3.97(\mathrm{~s}, 2 \mathrm{H},) .{ }^{13} \mathrm{C}$ NMR (101 MHz, DMSO-d 6$) \delta$ $160.02,157.70,149.02$, 147.04, 135.11, 131.94, 130.03, 129.90, $129.90,125.61,124.37,123.21,119.96,115.53,68.80,59.16$, 46.78, 22.01. LCMS $m / z$ calc for $\mathrm{C}_{19} \mathrm{H}_{16} \mathrm{ClN}_{6} \mathrm{O}_{2}^{+}[\mathrm{M}+\mathrm{H}]^{+}$: 395.1, found 395.0. The pure product was then added to a solution of $\mathrm{Ph}_{3} \mathrm{P}(1 \mathrm{~g}, 3.7 \mathrm{mmol})$ in THF $(100 \mathrm{~mL})$ and stirred for $2 \mathrm{~h}$ at $65{ }^{\circ} \mathrm{C}$. Subsequently, $10 \%$ ammonium hydroxide solution in water was added and stirred overnight at rt. The mixture was purified using column chromatography eluting the desired compound with 90:10 EtOAc:MeOH with $1 \% \mathrm{NH}_{3}$ $(0.7 \mathrm{~N})$. White solid (100 mg, 11\%). ${ }^{1} \mathrm{H}$ NMR (400 MHz, DMSO-d $)_{6} \delta 8.38(\mathrm{~s}, 1 \mathrm{H}, \mathrm{C} 8 \mathrm{H}), 8.10(\mathrm{~d}, J=2.5 \mathrm{~Hz}, 1 \mathrm{H}$, $\mathrm{C} 6 \mathrm{H}), 7.87(\mathrm{dd}, J=8.8,2.5 \mathrm{~Hz}, 1 \mathrm{H}), 7.72(\mathrm{~d}, J=8.8 \mathrm{~Hz}, 1 \mathrm{H})$, $7.27(\mathrm{~d}, J=8.3 \mathrm{~Hz}, 2 \mathrm{H}), 6.94(\mathrm{~d}, J=8.3 \mathrm{~Hz}, 2 \mathrm{H}), 4.29$ (dd, $J=$ $13.3,4.8 \mathrm{~Hz}, 1 \mathrm{H}), 3.94(\mathrm{~d}, J=10.9 \mathrm{~Hz}, 4 \mathrm{H}), 3.83(\mathrm{dd}, J=13.3$, $8.5 \mathrm{~Hz}, 1 \mathrm{H}), 3.38(\mathrm{t}, J=4.2 \mathrm{~Hz}, 1 \mathrm{H}) .{ }^{13} \mathrm{C} \mathrm{NMR}(101 \mathrm{MHz}$, DMSO-d $\left.{ }_{6}\right) \delta 160.04,158.33,149.77,147.25,134.76,131.53$, $129.88,129.88,125.49,123.74,123.40,120.01,115.44,115.44$, 71.86, 60.22, 49.49, 21.99. LCMS $m / z$ calc for $\mathrm{C}_{19} \mathrm{H}_{18} \mathrm{ClN}_{4} \mathrm{O}_{2}{ }^{+}$ $[\mathrm{M}+\mathrm{H}]^{+}$: 369.1, found 369.1. HRMS $\mathrm{m} / \mathrm{z}$ calc for $\mathrm{C}_{19} \mathrm{H}_{18} \mathrm{ClN}_{4} \mathrm{O}_{2}^{+}[\mathrm{M}+\mathrm{H}]^{+}$: 369.1113 , found 369.1118 .

2-(4-(3-(6-Chloro-4-oxoquinazolin-3(4H)-yl)-2oxopropoxy)phenyl)acetonitrile 43. To a mixture of 22 (0.5 $\mathrm{g}, 1.3 \mathrm{mmol})$ in DCM (50 mL), Dess-Martin periodinane (1g, $2.3 \mathrm{mmol}$ ) was added and stirred overnight at $\mathrm{rt}$. The mixture was washed with $1 \mathrm{M} \mathrm{NaOH}$, washed again with $\mathrm{H}_{2} \mathrm{O}$, and dried with anhydrous $\mathrm{Na}_{2} \mathrm{SO}_{4}$, and the mixture was reduced. The residue was purified using column chromatography EtOAc:PE 70:30 as eluent. White solid $(0.4 \mathrm{~g}, 76 \%) .{ }^{1} \mathrm{H}$ NMR (400 MHz, DMSO-d $\left.d_{6}\right) \delta 8.32(\mathrm{~s}, 1 \mathrm{H}), 8.09$ (d, $J=2.5$ $\mathrm{Hz}, 1 \mathrm{H}), 7.88(\mathrm{dd}, J=8.8,2.5 \mathrm{~Hz}, 1 \mathrm{H}), 7.75(\mathrm{~d}, J=8.8 \mathrm{~Hz}$, $1 \mathrm{H}), 7.30$ (d, $J=8.5 \mathrm{~Hz}, 2 \mathrm{H}), 7.02$ (d, $J=8.5 \mathrm{~Hz}, 2 \mathrm{H}), 5.16$ (s, 2H), 5.09 (s, 2H), $3.96(\mathrm{~s}, 2 \mathrm{H}) .{ }^{13} \mathrm{C}$ NMR (101 MHz, DMSO- $\left.d_{6}\right) \delta 200.35,159.59,157.48,148.97,147.17,135.23$, 132.07, 130.07, 130.07, 129.82, 125.50, 124.38, 122.97, 119.95, $115.53,115.35,71.57,52.63,22.01$. LCMS $m / z$ calc for $\mathrm{C}_{19} \mathrm{H}_{15} \mathrm{ClN}_{3} \mathrm{O}_{3}{ }^{+}[\mathrm{M}+\mathrm{H}]^{+}:$368.1, found 367.7, HRMS $\mathrm{m} / \mathrm{z}$ calc for $\mathrm{C}_{19} \mathrm{H}_{15} \mathrm{ClN}_{3} \mathrm{O}_{3}{ }^{+}[\mathrm{M}+\mathrm{H}]^{+}: 368.0796$, found 367.7

Preparation of 2-(4-(3-(6-Chloro-4-oxoquinazolin-3(4H)yl)-2-(ethylamino)propoxy)phenyl)acetonitrile 45. To a stirred solution of $42(20 \mathrm{mg}, 0.054 \mathrm{mmol})$ in $\mathrm{MeCN}$ (20 $\mathrm{mL})$, a mixture of iodoethane $(40 \mathrm{uL}, 0.54 \mathrm{mmol})$ and 
$\mathrm{Cs}_{2} \mathrm{CO}_{3}(13 \mathrm{mg}, 0.10 \mathrm{mmol})$ was added. The mixture was stirred at $60{ }^{\circ} \mathrm{C}$ for $16 \mathrm{~h}$. The mixture was purified using column chromatography eluting the desired compound with 95:5 EtOAc: $\mathrm{MeOH}$ containing $\mathrm{NH}_{3}(0.7 \mathrm{~N})$. White solid $(13$ mg, 65\%). ${ }^{1} \mathrm{H}$ NMR (400 MHz, DMSO-d $) \delta 8.34(\mathrm{~s}, 1 \mathrm{H})$, $8.10(\mathrm{~d}, J=2.5 \mathrm{~Hz}, 1 \mathrm{H}), 7.87(\mathrm{dd} J=8.7,2.5 \mathrm{~Hz}, 1 \mathrm{H}), 7.72$ $(\mathrm{d}, J=8.7 \mathrm{~Hz}, 1 \mathrm{H}), 7.26(\mathrm{~d}, J=8.4 \mathrm{~Hz}, 2 \mathrm{H}), 6.92(\mathrm{~d}, J=8.4$ $\mathrm{Hz}, 2 \mathrm{H}$ ), 4.23 (dd, $J=13.5,5.5 \mathrm{~Hz}, 1 \mathrm{H}), 4.00$ (dd, $J=10.0$, $5.2 \mathrm{~Hz}, 3 \mathrm{H}), 3.94(\mathrm{~s}, 2 \mathrm{H}), 3.23(\mathrm{~s}, 1 \mathrm{H}), 2.69$ (dq, $J=14.1,7.1$ $\mathrm{Hz}, 1 \mathrm{H}), 1.90(\mathrm{~s}, 1 \mathrm{H}), 0.91(\mathrm{t}, J=7.1 \mathrm{~Hz}, 3 \mathrm{H}) .{ }^{13} \mathrm{C}$ NMR $(101$ $\left.\mathrm{MHz}, \mathrm{DMSO}-d_{6}\right) \delta 160.03,158.27,149.76,147.20,134.86$, 131.60, 129.91, 129.75, 129.75, 125.51, 123.79, 123.22, 120.00, $115.44,115.44,68.72,55.03,48.62,41.25,21.99,15.96$. LCMS $m / z$ calc for $\mathrm{C}_{21} \mathrm{H}_{22} \mathrm{ClN}_{4} \mathrm{O}_{2}^{+}[\mathrm{M}+\mathrm{H}]^{+}:$397.1, found 397.0.

General Procedure (3) for synthesis of compounds 4649. To a solution of correspondent acid anhydride, 42 (50 mg, $0.1 \mathrm{mmol}$ ) was added and stirred at $30{ }^{\circ} \mathrm{C}$ for $3 \mathrm{~h}$. The reaction was concentrated to dryness and the residue was dissolved in EtOAc $(20 \mathrm{~mL})$ and washed with saturated aqueous $\mathrm{NaOH}$ $(20 \mathrm{~mL})$ and water $(20 \mathrm{~mL})$. The organic phase was concentrated to afford the desired product without further purification.

Preparation of N-(1-(6-Chloro-4-oxoquinazolin-3(4H)-yl)3-(4-(cyanomethyl)phenoxy)propan-2-yl)acetamide 46. The reaction was carried out in acetic anhydride $(4 \mathrm{~mL})$ according to general procedure (3). White solid (53 mg, 95\%). ${ }^{1} \mathrm{H}$ NMR $\left(400 \mathrm{MHz}, \mathrm{DMSO}-d_{6}\right) \delta 8.28(\mathrm{~s}, 1 \mathrm{H}), 8.17-8.07(\mathrm{~m}, 2 \mathrm{H})$, 7.87 (dd, $J=8.7,2.5 \mathrm{~Hz}, 1 \mathrm{H}), 7.72(\mathrm{~d}, J=8.7 \mathrm{~Hz}, 1 \mathrm{H}), 7.28$ $(\mathrm{m}, 1 \mathrm{H}), 7.02-6.94(\mathrm{~m}, 2 \mathrm{H}), 4.55(\mathrm{tt}, J=8.9,4.8 \mathrm{~Hz}, 1 \mathrm{H})$, 4.39 (dd, $J=13.6,4.5 \mathrm{~Hz}, 1 \mathrm{H}), 4.07$ (dd, $J=5.3,1.6 \mathrm{~Hz}, 2 \mathrm{H})$, 4.01-3.90 (m, 3H), $1.76(\mathrm{~s}, 3 \mathrm{H}) .{ }^{13} \mathrm{C}$ NMR $(101 \mathrm{MHz}$, DMSO- $\left.d_{6}\right) \delta 170.04,159.91,158.09,149.01,147.06,134.93$, 131.76, 129.96, 129.81, 129.81, 125.52, 124.03, 123.17, 119.99, $115.55,115.55,68.45,47.87,47.33,22.96,22.00$. LCMS $m / z$ calc for $\mathrm{C}_{21} \mathrm{H}_{20} \mathrm{ClN}_{4} \mathrm{O}_{3}^{+}[\mathrm{M}+\mathrm{H}]^{+}: 411.1$, found 411.1

$\mathrm{N}$-(1-(6-Chloro-4-oxoquinazolin-3(4H)-yl)-3-(4(cyanomethyl)phenoxy)propan-2-yl)propionamide 47. The reaction was carried out in propionic anhydride $(4 \mathrm{~mL})$ according to general procedure (3). White solid $(50.32 \mathrm{mg}$, $87.12 \%) .{ }^{1} \mathrm{H}$ NMR (400 MHz, DMSO- $\left.d_{6}\right) \delta 8.28(\mathrm{~s}, 1 \mathrm{H}), 8.10$ (d, $J=2.4 \mathrm{~Hz}, 1 \mathrm{H}), 8.02$ (d, $J=8.8 \mathrm{~Hz}, 1 \mathrm{H}), 7.87$ (dd, $J=8.7$, $2.5 \mathrm{~Hz}, 1 \mathrm{H}), 7.71(\mathrm{~d}, J=8.7 \mathrm{~Hz}, 1 \mathrm{H}), 7.33-7.24(\mathrm{~m}, 2 \mathrm{H})$, $7.03-6.94(\mathrm{~m}, 2 \mathrm{H}), 4.56(\mathrm{tt}, J=9.7,4.8 \mathrm{~Hz}, 1 \mathrm{H}), 4.40(\mathrm{dd}, J=$ $13.5,4.4 \mathrm{~Hz}, 1 \mathrm{H}), 4.12-4.02(\mathrm{~m}, 2 \mathrm{H}), 4.02-3.91(\mathrm{~m}, 1 \mathrm{H})$, $3.96(\mathrm{~s}, 2 \mathrm{H}), 2.02(\mathrm{q}, J=7.6 \mathrm{~Hz}, 2 \mathrm{H}), 0.85(\mathrm{t}, J=7.6 \mathrm{~Hz}, 3 \mathrm{H})$. ${ }^{13} \mathrm{C}$ NMR (101 MHz, DMSO- $\left.d_{6}\right) \delta 173.80,159.96,158.11$, $149.07,147.07,134.91,131.73,129.92,129.82,125.52,124.02$, $123.18,119.99,115.57,115.40,68.49,47.82,47.24,28.92$, 22.00, 10.19. LCMS $m / z$ calc for $\mathrm{C}_{22} \mathrm{H}_{22} \mathrm{ClN}_{4} \mathrm{O}_{3}{ }^{+}[\mathrm{M}+\mathrm{H}]^{+}$: 424.1, found 424.0.

$\mathrm{N}$-(1-(6-Chloro-4-oxoquinazolin-3(4H)-yl)-3-(4(cyanomethyl)phenoxy)propan-2-yl)butyramide 48. Reaction was carried out in butyric anhydride $(4 \mathrm{~mL})$ according to general procedure (3). White solid (54.02 mg, 90.35\%). ${ }^{1} \mathrm{H}$ NMR (400 MHz, DMSO) $\delta 8.28(\mathrm{~s}, 1 \mathrm{H}), 8.10(\mathrm{~d}, J=2.5 \mathrm{~Hz}$, $1 \mathrm{H}), 8.04$ (d, $J=8.9 \mathrm{~Hz}, 1 \mathrm{H}), 7.87$ (dd, $J=2.5,8.8 \mathrm{~Hz}, 1 \mathrm{H})$, $7.71(\mathrm{~d}, J=8.6 \mathrm{~Hz}, 1 \mathrm{H}), 7.31-7.26(\mathrm{~m}, 2 \mathrm{H}), 7.01-6.96(\mathrm{~m}$, $2 \mathrm{H}), 4.59(\mathrm{dq}, J=4.6,9.3 \mathrm{~Hz}, 1 \mathrm{H}), 4.39(\mathrm{dd}, J=4.4,13.6 \mathrm{~Hz}$, $1 \mathrm{H}), 4.07$ (d, $J=5.5 \mathrm{~Hz}, 2 \mathrm{H}), 3.98-3.93(\mathrm{~m}, 3 \mathrm{H}), 1.99(\mathrm{t}, J=$ $7.2 \mathrm{~Hz}, 2 \mathrm{H}), 1.41-1.30(\mathrm{~m}, 2 \mathrm{H}), 0.96-0.83(\mathrm{~m}, 1 \mathrm{H}), 0.68(\mathrm{t}$, $J=7.3 \mathrm{~Hz}, 3 \mathrm{H}) \cdot{ }^{13} \mathrm{C}$ NMR $\left(101 \mathrm{MHz}, \mathrm{DMSO}-d_{6}\right) \delta 172.85$, 159.94, 158.12, 149.06, 147.09, 134.92, 131.73, 129.92, 129.82, $125.51,124.01,123.17,120.00,115.56,115.22$, 68.54, 47.82,
47.15, 37.67, 22.01, 18.92, 13.82. LCMS $m / z$ calc for $\mathrm{C}_{23} \mathrm{H}_{24} \mathrm{ClN}_{4} \mathrm{O}_{3}^{+}[\mathrm{M}+\mathrm{H}]^{+}$: 439.1, found 438.9.

General Procedure (4) for Compounds 49-51. To a stirred solution of of the corresponding acetic acid ( 1 equiv) in DMF $(20 \mathrm{~mL})$ was added a mixture of 42 (1.35 equiv), PyBrop ( 2 equiv), and trimethylamine ( 3 equiv). The mixture was stirred for $4 \mathrm{~h}$ at $\mathrm{rt}$. The mixture was purified using column chromatography eluting the desired compound with DCM: $\mathrm{MeOH}$ 9:1 with $0.1 \% \mathrm{NH}_{3}(0.7 \mathrm{~N})$

Preparation of N-(1-(6-Chloro-4-oxoquinazolin-3(4H)-yl)3-(4-(cyanomethyl)phenoxy)propan-2-yl)-2(dimethylamino)acetamide 49. The title compound was prepared according to general procedure (4) using (dimethyl amino) acetic acid (12 mg, $0.12 \mathrm{mmol}), 42$ (60 mg, 0.16 $\mathrm{mmol}$ ), PyBrop (0.1 g, $0.24 \mathrm{mmol})$, and trimethylamine (46 $\mathrm{mg}, 0.36 \mathrm{mmol})$. White solid (28 mg, 54\%). ${ }^{1} \mathrm{H}$ NMR (400 MHz, DMSO- $\left.d_{6}\right) \delta 8.32(\mathrm{~s}, 1 \mathrm{H}), 8.10(\mathrm{~d}, J=2.5 \mathrm{~Hz}, 1 \mathrm{H}), 8.02$ $(\mathrm{d}, J=9.2 \mathrm{~Hz}, 1 \mathrm{H}), 7.87(\mathrm{dd} J=8.7,2.5 \mathrm{~Hz}, 1 \mathrm{H}), 7.71(\mathrm{~d}, J=$ $8.7 \mathrm{~Hz}, 1 \mathrm{H}), 7.29(\mathrm{~d}, J=8.7 \mathrm{~Hz}, 2 \mathrm{H}), 7.03-6.95(\mathrm{~m}, 2 \mathrm{H})$, $4.63(\mathrm{~d}, J=9.2 \mathrm{~Hz}, 1 \mathrm{H}), 4.39$ (dd, $J=13.5,4.1 \mathrm{~Hz}, 1 \mathrm{H}), 4.16-$ $4.04(\mathrm{~m}, 3 \mathrm{H}), 3.96(\mathrm{~s}, 2 \mathrm{H}), 2.76(\mathrm{~d}, J=1.3 \mathrm{~Hz}, 2 \mathrm{H}), 2.12(\mathrm{~s}$, $6 \mathrm{H}) .{ }^{13} \mathrm{C}$ NMR (101 MHz, DMSO- $\left.d_{6}\right) \delta 170.53,159.96$, $158.10,149.02$, 147.07, 134.93, 131.77, 129.95, 129.84, 129.84, $125.50,124.04,123.18,119.99,115.57,115.57,68.33,63.14$, 47.54, 46.36, 45.82, 45.82, 22.00. LCMS $m / z$ calc for $\mathrm{C}_{23} \mathrm{H}_{25} \mathrm{ClN}_{5} \mathrm{O}_{3}^{+}[\mathrm{M}+\mathrm{H}]^{+}$: 454.1, found 453.9.

$\mathrm{N}$-(1-(6-Chloro-4-oxoquinazolin-3(4H)-yl)-3-(4(cyanomethyl)phenoxy)propan-2-yl)-3-(dimethylamino)propanamide 50 . The title compound was prepared according general procedure (4) using 3-(dimethylamino) propionic acid (15 mg, $0.09 \mathrm{mmol}$ ), 42 (44 mg, $0.12 \mathrm{mmol}$ ), PyBrop (0.08 g, $0.18 \mathrm{mmol}$ ), and trimethylamine ( $35 \mathrm{mg}, 0.27 \mathrm{mmol})$. White solid (27 mg, 59.67\%). ${ }^{1} \mathrm{H}$ NMR (400 MHz, DMSO- $d_{6}$ ) $\delta$ $8.41-8.29(\mathrm{~m}, 2 \mathrm{H}), 8.11(\mathrm{dd}, J=11.0,2.5 \mathrm{~Hz}, 1 \mathrm{H}), 7.89(\mathrm{td}, J$ $=9.0,2.6 \mathrm{~Hz}, 1 \mathrm{H}), 7.73(\mathrm{dd}, J=10.9,8.7 \mathrm{~Hz}, 1 \mathrm{H}), 7.30(\mathrm{dd}, J$ $=7.8,5.7 \mathrm{~Hz}, 2 \mathrm{H}), 7.03-6.94(\mathrm{~m}, 2 \mathrm{H}), 4.59(\mathrm{dq}, J=9.2,4.5$ $\mathrm{Hz}, 1 \mathrm{H}), 4.48-4.31(\mathrm{~m}, 1 \mathrm{H}), 4.20(\mathrm{~s}, 1 \mathrm{H}), 4.15-3.94(\mathrm{~m}$, $3 \mathrm{H}), 3.96(\mathrm{~s}, 2 \mathrm{H}), 2.65-2.53(\mathrm{~m}, 2 \mathrm{H}), 2.28(\mathrm{t}, J=7.1 \mathrm{~Hz}$, $1 \mathrm{H}), 2.25$ (s, 4H), $2.10(\mathrm{~s}, 1 \mathrm{H}), 1.19(\mathrm{t}, J=7.1 \mathrm{~Hz}, 1 \mathrm{H}) .{ }^{13} \mathrm{C}$ NMR $\left(101 \mathrm{MHz}, \mathrm{DMSO}-d_{6}\right) \delta 170.31,161.94,158.04,149.09$, 147.04, 135.06, 131.77, 130.06, 129.82 125.53, 124.41, 123.17, 120.00, 115.71, 68.32, 53.49, 47.56, 45.94, 43.09, 30.92, 29.16, 25.92, 22.02. LCMS $m / z$ calc for $\mathrm{C}_{24} \mathrm{H}_{27} \mathrm{ClN}_{5} \mathrm{O}_{3}{ }^{+}[\mathrm{M}+\mathrm{H}]^{+}$: 468.1, found 467.9 .

$\mathrm{N}$-(1-(6-Chloro-4-oxoquinazolin-3(4H)-yl)-3-(4(cyanomethyl)phenoxy)propan-2-yl)-4-(dimethylamino)butanamide 51 . The title compound was prepared according general procedure (4) using 4-(dimethylamino) butyric acid (16 mg, $0.09 \mathrm{mmol}) 42$ (44 mg, $0.12 \mathrm{mmol}$ ), PyBrop (0.08 g, $0.18 \mathrm{mmol}$ ), and trimethylamine $(35 \mathrm{mg}, 0.27 \mathrm{mmol})$. White solid (27 mg, 58.76\%). ${ }^{1} \mathrm{H}$ NMR (400 MHz, DMSO- $\left.d_{6}\right) \delta$ $8.38-8.25(\mathrm{~m}, 2 \mathrm{H}), 8.11(\mathrm{~d}, J=2.6 \mathrm{~Hz}, 1 \mathrm{H}), 7.88(\mathrm{dd}, J=8.7$, $2.5 \mathrm{~Hz}, 1 \mathrm{H}), 7.72(\mathrm{~d}, J=8.6 \mathrm{~Hz}, 1 \mathrm{H}), 7.34-7.25(\mathrm{~m}, 2 \mathrm{H})$, $7.04-6.95(\mathrm{~m}, 2 \mathrm{H}), 4.58(\mathrm{tt}, J=9.7,4.8 \mathrm{~Hz}, 1 \mathrm{H}), 4.41(\mathrm{dd}, J=$ 13.5, $4.2 \mathrm{~Hz}, 1 \mathrm{H}), 4.10(\mathrm{~d}, J=5.4 \mathrm{~Hz}, 2 \mathrm{H}), 4.04-3.93(\mathrm{~m}$, $3 \mathrm{H}), 3.18$ (d, $J=4.5 \mathrm{~Hz}, 1 \mathrm{H}), 2.71(\mathrm{~d}, J=14.3 \mathrm{~Hz}, 2 \mathrm{H}), 2.56$ (s, $5 \mathrm{H}), 2.13(\mathrm{td}, J=7.3,3.1 \mathrm{~Hz}, 2 \mathrm{H}), 1.75-1.57(\mathrm{~m}, 2 \mathrm{H}) .{ }^{13} \mathrm{C}$ NMR (101 MHz, DMSO- $\left.d_{6}\right) \delta 172.03,159.96,158.08,149.13$, 147.03, 134.96, 131.79, 129.94, 129.84, 125.57, 124.08, 123.19, 120.01, 115.57, 75.48, 68.41, 56.92, 47.84, 47.39, 43.02, 39.70, $39.49,32.42,22.01$. LCMS $m / z$ calc for $\mathrm{C}_{25} \mathrm{H}_{29} \mathrm{ClN}_{5} \mathrm{O}_{3}{ }^{+}[\mathrm{M}+$ $\mathrm{H}]^{+}$: 482.2 , found 481.8 . 
6-Chloro-3-(3-chloropropyl)quinazolin-4(3H)-one 52. To a stirred solution of $2(0.3 \mathrm{~g}, 1.6 \mathrm{mmol})$ in $\mathrm{MeCN}(50 \mathrm{~mL}), 1-$ bromo-3-chloropropane (0.3 g, $1.9 \mathrm{mmol}), \mathrm{Cs}_{2} \mathrm{CO}_{3}(1 \mathrm{~g}, 3.2$ $\mathrm{mmol}$ ), and TBAI (59 $\mathrm{mg}, 0.16 \mathrm{mmol}$ ) were added. The formed mixture was refluxed overnight. Subsequently, the reaction was cooled down, filtered and reduced. The residue was chromatographed using PE:EtOAc 1:1 as an eluent. White solid (0.3 g, 73\%). ${ }^{1} \mathrm{H}$ NMR (400 MHz, DMSO- $\left.d_{6}\right) \delta 8.41(\mathrm{~s}$, $1 \mathrm{H}), 8.09$ (d, $J=2.5 \mathrm{~Hz}, 1 \mathrm{H}), 7.86(\mathrm{dd}, J=8.7,2.5 \mathrm{~Hz}, 1 \mathrm{H})$, $7.71(\mathrm{~d}, J=8.7 \mathrm{~Hz}, 1 \mathrm{H}), 4.11(\mathrm{t}, J=6.6 \mathrm{~Hz}, 2 \mathrm{H}), 3.72(\mathrm{t}, J=$ $6.6 \mathrm{~Hz}, 2 \mathrm{H}), 2.19$ (p, J = 6.6 Hz, 2H). ${ }^{13} \mathrm{C} \mathrm{NMR}(101 \mathrm{MHz}$, DMSO-d $d_{6} \delta 159.84,148.92,147.15,134.84,131.75,129.94$, $125.46,123.33,44.69,43.04,31.59$. LCMS $m / z$ calc for $\mathrm{C}_{11} \mathrm{H}_{11} \mathrm{Cl}_{2} \mathrm{~N}_{2} \mathrm{O}^{+}[\mathrm{M}+\mathrm{H}]^{+}:$257.0, found 259.1.

6-Chloro-3-(3-chloro-2-methylpropyl)quinazolin-4(3H)one 53. To a stirred solution of $2(0.3 \mathrm{~g}, 1.6 \mathrm{mmol})$ in $\mathrm{MeCN}$ (50 mL), 1-bromo-3-chloro-2-methylpropane (0.3 g, 1.9 $\mathrm{mmol}$ ), $\mathrm{Cs}_{2} \mathrm{CO}_{3}$ (1 g, $3.2 \mathrm{mmol}$ ), and TBAI (59 mg, 0.16 $\mathrm{mmol}$ ) were added. The formed mixture was refluxed overnight. Subsequently, the reaction was cooled down, filtered, and reduced. The residue was chromatographed using PE:EtOAc 1:1 as an eluent. White solid (0.3 g, 71\%). ${ }^{1} \mathrm{H}$ NMR (400 MHz, DMSO- $d_{6}$ ) $\delta 8.38(\mathrm{~s}, 1 \mathrm{H}), 8.10$ (d, $J=$ $2.5 \mathrm{~Hz}, 1 \mathrm{H}), 7.86(\mathrm{dd}, J=8.8,2.5,1 \mathrm{H}), 7.72(\mathrm{~d}, J=8.8 \mathrm{~Hz}$, $1 \mathrm{H}), 4.08-3.88(\mathrm{~m}, 2 \mathrm{H}), 3.73-3.60(\mathrm{~m}, 2 \mathrm{H}), 2.49-2.41(\mathrm{~m}$, $1 \mathrm{H}), 0.99$ (d, $J=6.8 \mathrm{~Hz}, 3 \mathrm{H}) .{ }^{13} \mathrm{C}$ NMR (101 MHz, DMSO$\left.d_{6}\right) \delta 160.02,149.05,147.08,134.98,131.81,130.05,125.63$, $123.32,50.79,49.03,34.73,15.55$. LCMS $m / z$ calc for $\mathrm{C}_{12} \mathrm{H}_{13} \mathrm{C}_{12} \mathrm{~N}_{2} \mathrm{O}^{+}[\mathrm{M}+\mathrm{H}]^{+}$: 271.0, found 270.8 .

General Procedure (5) for Preparation of 54-55. To a stirred solution of $\mathbf{5 2}$ or $\mathbf{5 3}(0.3 \mathrm{~g}, 1 \mathrm{mmol})$, TBAI $(37 \mathrm{mg}, 0.1$ $\mathrm{mmol})$ and $\mathrm{Cs}_{2} \mathrm{CO}_{3}(1 \mathrm{~g}, 1.3 \mathrm{mmol})$ in $\mathrm{MeCN}(100 \mathrm{~mL})$ and 4-hydroxyphenyl acetonitrile $(0.15 \mathrm{~g}, 1.1 \mathrm{mmol})$ was added. The mixture was heated at $100{ }^{\circ} \mathrm{C}$, overnight. The mixture was filtered and purified using column chromatography eluting the desired compound with 40:60 PE:EtOAc.

2-(4-(3-(6-Chloro-4-oxoquinazolin-3(4H)-yl)-2methylpropoxy)phenyl)acetonitrile 54. The title compound was prepared according to general procedure (5). White solid (200 mg, 49\%). ${ }^{1} \mathrm{H}$ NMR (400 MHz, DMSO-d $) \delta 8.39(\mathrm{~s}, 1 \mathrm{H}$ $\mathrm{C} 8 \mathrm{H}), 8.09(\mathrm{~d}, J=2.5 \mathrm{~Hz}, 1 \mathrm{H}), 7.87(\mathrm{dd}, J=8.7,2.5 \mathrm{~Hz}, 1 \mathrm{H})$, $7.72(\mathrm{~d}, J=8.7 \mathrm{~Hz}, 1 \mathrm{H}), 7.24-7.20(\mathrm{~m}, 2 \mathrm{H}), 6.86-6.79(\mathrm{~m}$, $2 \mathrm{H}), 4.12(\mathrm{~m}, 2 \mathrm{H}),, 4.01(\mathrm{~m}, 1 \mathrm{H}),, 3.92(\mathrm{~d}, J=5.5 \mathrm{~Hz}, 4 \mathrm{H})$, $1.02(\mathrm{~d}, J=6.8 \mathrm{~Hz}, 3 \mathrm{H}) .{ }^{13} \mathrm{CNMR}\left(101 \mathrm{MHz}, \mathrm{DMSO}-d_{6}\right) \delta$ 160.02, 158.23, 149.28, 147.13, 134.87, 131.74, 129.95, 129.69, $129.69,125.53,123.63,123.30,119.99,115.25,115.25,70.95$, $50.05,21.97,14.96$. LCMS $m / z$ calc for $\mathrm{C}_{20} \mathrm{H}_{19} \mathrm{ClN}_{3} \mathrm{O}_{2}^{+}[\mathrm{M}+$ $\mathrm{H}]^{+}: 368.1$, found 367.7

2-(4-(3-(6-Chloro-4-oxoquinazolin-3(4H)-yl)propoxy)phenyl)acetonitrile 55. The title compound was prepared according to general procedure (5). White solid (100 mg, 40\%). ${ }^{1} \mathrm{H}$ NMR (400 MHz, DMSO- $d_{6}$ ) $\delta 8.41$ (s, $\left.1 \mathrm{H}\right), 8.10$ $(\mathrm{d}, J=2.6 \mathrm{~Hz}, 1 \mathrm{H}), 7.87(\mathrm{dd}, J=8.7,2.6 \mathrm{~Hz}, 1 \mathrm{H}), 7.72(\mathrm{~d}, J=$ $8.7 \mathrm{~Hz}, 1 \mathrm{H}), 7.28-7.19(\mathrm{~m}, 2 \mathrm{H}), 6.91-6.83(\mathrm{~m}, 2 \mathrm{H}), 4.18(\mathrm{t}$, $J=6.4 \mathrm{~Hz}, 2 \mathrm{H}), 4.05(\mathrm{t}, J=6.4 \mathrm{~Hz}, 2 \mathrm{H}), 3.93(\mathrm{~s}, 2 \mathrm{H}), 2.18(\mathrm{p}$, $J=6.4 \mathrm{~Hz}, 2 \mathrm{H}) .{ }^{13} \mathrm{C}$ NMR $\left(101 \mathrm{MHz}, \mathrm{DMSO}-d_{6}\right) \delta 159.85$, $158.18,149.12$, 147.20, 134.84, 131.72, 129.95, 129.72, 129.72, 125.47, 123.63, 123.33, 120.00, 115.31, 115.31, 65.72, 44.57, 28.25, 21.98. LCMS $m / z$ calc for $\mathrm{C}_{19} \mathrm{H}_{17} \mathrm{ClN}_{3} \mathrm{O}_{2}{ }^{+}[\mathrm{M}+\mathrm{H}]^{+}$: 354.1 , found 354.0

6-Chloro-3-(2-hydroxy-3-(4-((5-methyl-1,2,4-oxadiazol-3yl)methyl)phenoxy)propyl)quinazolin-4(3H)-one 56. To a stirred solution of $22(0.1 \mathrm{~g}, 0.27 \mathrm{mmol})$ in 1.1 mixture of
EtOH and $\mathrm{H}_{2} \mathrm{O}(20 \mathrm{~mL})$ was added hydroxylamine $\mathrm{HCl}(22$ $\mathrm{mg}, 0.32 \mathrm{mmol})$ and $\mathrm{NaOH}(13 \mathrm{mg}, 0.24 \mathrm{mmol})$. The mixture was refluxed for 2 days before it was reduced and extracted with EtOAc $(10 \mathrm{~mL} \times 3)$. The organic layer was then reduced and dried over $\mathrm{MgSO}_{4}$. The residue was then purified using flash chromatography using PE:EtOAc 7:3. White solid (95 mg, 81\%).

${ }^{1} \mathrm{H}$ NMR (400 MHz, methanol- $\left.d_{4}\right) \delta 6.75(\mathrm{~s}, 1 \mathrm{H}), 6.65(\mathrm{~d}, J$ $=2.4 \mathrm{~Hz}, 1 \mathrm{H}), 6.26(\mathrm{dd}, J=8.8,2.5 \mathrm{~Hz}, 1 \mathrm{H}), 6.20-6.09(\mathrm{~m}$, $1 \mathrm{H}), 5.71-5.61(\mathrm{~m}, 2 \mathrm{H}), 5.35(\mathrm{~d}, J=8.7 \mathrm{~Hz}, 2 \mathrm{H}), 2.94(\mathrm{dt}, J$ $=13.6,3.6 \mathrm{~Hz}, 1 \mathrm{H}), 2.81-2.60(\mathrm{~m}, 1 \mathrm{H}), 2.56-2.35(\mathrm{~m}, 5 \mathrm{H})$, 0.99 (s, 3H). ${ }^{13} \mathrm{C}$ NMR (100 MHz, methanol- $\left.d_{4}\right) \delta$ 175.82, $168.04,158.97,156.32,147.44,144.96,133.03$, 131.12, 128.19, $127.06,126.68,123.77,121.33,112.93,68.39,65.39,48.27$, 29.03, 9.04. LCMS calculated for $\mathrm{C}_{21} \mathrm{H}_{20} \mathrm{ClN}_{4} \mathrm{O}_{4}^{+}[\mathrm{M}+\mathrm{H}]^{+}$: 427.1 found 427.2, HRMS calculated for $\mathrm{C}_{21} \mathrm{H}_{20} \mathrm{ClN}_{4} \mathrm{O}_{4}{ }^{+}[\mathrm{M}+$ $\mathrm{H}]^{+}: 427.1168$ found 427.1157 .

6-Chloro-3-(2-hydroxy-3-(4-((3-methyl-1H-1,2,4-triazol-5yl)methyl)phenoxy)propyl)quinazolin-4(3H)-one 57. To a stirred solution of $22(0.3 \mathrm{~g}, 0.8 \mathrm{mmol})$ in methanol (50 $\mathrm{mL})$, acetylhydrazine $(0.17 \mathrm{~g}, 2.4 \mathrm{mmol})$ and sodium methoxide $(0.1 \mathrm{~g}, 1.9 \mathrm{mmol})$ was added. The mixture was refluxed at $80{ }^{\circ} \mathrm{C}$ for $16 \mathrm{~h}$. The mixture was diluted with EtOAc $(50 \mathrm{~mL})$. Then, the EtOAc was washed with water $(3 \times$ $50 \mathrm{~mL}$ ), dry it with $\mathrm{Na} 2 \mathrm{SO} 4$ anhydrous and concentrate the mixture. The residue was purified using column chromatography eluting the desired compound with 95:5 EtOAc: $\mathrm{MeOH}$ containing $\mathrm{NH}_{3}(0.7 \mathrm{~N})$. White solid $(50 \mathrm{mg}, 14 \%) .{ }^{1} \mathrm{H}$ NMR $\left(400 \mathrm{MHz}, \mathrm{DMSO}-d_{6}\right) \delta 13.27(\mathrm{~s}, 1 \mathrm{H}, \mathrm{NH}), 8.31(\mathrm{~s}, 1 \mathrm{H}$,$) ,$ $8.10(\mathrm{~d}, J=2.6 \mathrm{~Hz}, 1 \mathrm{H}), 7.87(\mathrm{dd}, J=8.7,2.6 \mathrm{~Hz}, 1 \mathrm{H}), 7.72$ $(\mathrm{d}, J=8.7 \mathrm{~Hz}, 1 \mathrm{H}), 7.16(\mathrm{~d}, J=8.0 \mathrm{~Hz}, 2 \mathrm{H}), 6.86(\mathrm{~d}, J=8.0$ $\mathrm{Hz}, 2 \mathrm{H}), 5.50(\mathrm{~d}, J=5.7 \mathrm{~Hz}, 1 \mathrm{H}), 4.34(\mathrm{dd}, J=13.4,3.7 \mathrm{~Hz}$, $1 \mathrm{H}), 4.21-4.12(\mathrm{~m}, 1 \mathrm{H}), 3.97(\mathrm{~s}, 2 \mathrm{H}), 3.93-3.80(\mathrm{~m}, 3 \mathrm{H}$, C13), 2.25 (s, 3H). ${ }^{13} \mathrm{C}$ NMR (101 MHz, DMSO-d $d_{6} \delta$ 162.77, 159.96, 157.26, 153.16, 149.73, 147.22, 134.87, 131.62, $130.11,130.11,129.91,125.49,123.32,114.80,114.80,70.65$, 66.47, 50.05, 33.63, 12.01. LCMS $m / z$ calc for $\mathrm{C}_{21} \mathrm{H}_{21} \mathrm{ClN}_{5} \mathrm{O}_{3}{ }^{+}$ $[\mathrm{M}+\mathrm{H}]^{+}:$426.1, found 426.2

3-(3-(4-((1H-tetrazol-5-yl)methyl)phenoxy)-2-hydroxypropyl)-6-chloroquinazolin-4(3H)-one 58. To a stirred solution of $22(0.3 \mathrm{~g}, 8 \mathrm{mmol})$ in DMF $(50 \mathrm{~mL}), \mathrm{NaN}_{3}$ $(0.15 \mathrm{~g}, 24 \mathrm{mmol})$ and $\mathrm{Et}_{3} \mathrm{~N} . \mathrm{HCl}(0.3 \mathrm{~g}, 24 \mathrm{mmol})$ were added. The reaction mixture was heated at $130{ }^{\circ} \mathrm{C}$ for $16 \mathrm{~h}$. The reaction was concentrated to dryness, and the desired product was isolated using column chromatography eluting the desired compound with 95:5 EtOAc:acetic acid. Brown solid (250 mg, 75\%). ${ }^{1} \mathrm{H}$ NMR (400 MHz, DMSO-d $\left.d_{6}\right) \delta 8.32(\mathrm{~s}$, $1 \mathrm{H}), 8.11$ (d, $J=2.5 \mathrm{~Hz}, 1 \mathrm{H}), 7.87$ (dd, $\mathrm{J}=8.7,2.5 \mathrm{~Hz}, 1 \mathrm{H})$, 7.72 (d, $J=8.7 \mathrm{~Hz}, 1 \mathrm{H}$ ), $7.13(\mathrm{~d}, J=8.4 \mathrm{~Hz}, 2 \mathrm{H}), 6.86-6.74$ $(\mathrm{d}, J=8.4 \mathrm{~Hz}, 2 \mathrm{H}), 5.64(\mathrm{~s}, 1 \mathrm{H}), 4.34(\mathrm{dd}, J=13.4,3.6 \mathrm{~Hz}$, $1 \mathrm{H}), 4.14(\mathrm{dt}, J=9.0,4.4 \mathrm{~Hz}, 1 \mathrm{H}), 3.95(\mathrm{~d}, J=5.2 \mathrm{~Hz}, 2 \mathrm{H})$, 3.91 (s, 2H), 3.90-3.86 (m, 1H). ${ }^{13} \mathrm{C}$ NMR (101 MHz, DMSO- $\left.d_{6}\right) \delta 175.44,163.93,160.30,159.94,156.85,149.77$, 147.23, 134.84, 133.58, 131.59, 129.98, 125.50, 123.32, 114.51, 70.72, 66.52, 50.05, 31.27. LCMS $m / z$ calc for $\mathrm{C}_{19} \mathrm{H}_{17} \mathrm{ClN}_{6} \mathrm{O}_{3}{ }^{+}$ $[\mathrm{M}+\mathrm{H}]^{+}:$413.1, found 412.7 .

2-(4-(3-(6-Chloro-4-oxoquinazolin-3(4H)-yl)-2hydroxypropoxy)phenyl)acetamide 59. To a stirred solution of $22(0.1 \mathrm{~g}, 0.27 \mathrm{mmol})$ in $30 \% \mathrm{H}_{2} \mathrm{O}_{2}$ :DMSO $(100 \mathrm{~mL})$, $\mathrm{Cs}_{2} \mathrm{CO}_{3}(0.3 \mathrm{~g}$, $0.54 \mathrm{mmol})$ was added, and the resulting mixture was stirred for $30 \mathrm{~min}$ in rt. The mixture was purified using column chromatography eluting the desired compound with $100 \%$ EtOAc. White solid (0.1 g, 96\%). ${ }^{1} \mathrm{H}$ NMR (400 
Table 4. Bacterial Strains and Plasmids Used in This Study

\begin{tabular}{|c|c|c|}
\hline strain or plasmid & relevant characteristics & reference or origin \\
\hline \multicolumn{3}{|c|}{ P. aeruginosa } \\
\hline PAO1-L & wild type PAO1, Lausanne subline. & B. Holloway via D. Haas \\
\hline $\begin{array}{l}\text { PAO1-L mCTX:: } P_{p q s A^{-}} \\
\text {lux }\end{array}$ & PAO1-L with chromosomal mini-CTX:: $\mathrm{P}_{p q s A}-l u x$ insertion; $\mathrm{Tc}^{\mathrm{R}}$ & 47 \\
\hline PAO1-N & wild type PAO1, Nottingham subline & B. Holloway \\
\hline PA14 & wild type UCBPP-PA14 & 48 \\
\hline PALESB58 & cystic fibrosis isolate & 49 \\
\hline PAK6085 & cystic fibrosis isolate & 36 \\
\hline PA7-48 & cystic fibrosis isolate & 36 \\
\hline PA14 mCTX:: $P_{p q s A}-l u x$ & PA14 with chromosomal mini-CTX:: $\mathrm{P}_{p q s A}-l u x$ insertion; $\mathrm{Tc}^{\mathrm{R}}$ & 47 \\
\hline \multicolumn{3}{|c|}{ Plasmids } \\
\hline $\operatorname{mini}-\mathrm{CTX}: \mathrm{P}_{p q s A}-l u x$ & $\begin{array}{l}\text { R6K-based mini-CTX suicide plasmid for the chromosomal insertion of a } \mathrm{P}_{p q s \mathrm{~A}}-l u x \text { transcriptional reporter } \\
\text { fusion; } \mathrm{Tc}^{\mathrm{R}}\end{array}$ & 50 \\
\hline pMMG & pME6032 $\Delta$ lacI constitutively expressing GFP from the $\mathrm{P}_{\text {tac }}$ promoter & 51 \\
\hline
\end{tabular}

MHz, DMSO- $\left.d_{6}\right) \delta 8.32(\mathrm{~s}, 1 \mathrm{H}), 8.12(\mathrm{~d}, J=2.5 \mathrm{~Hz}, 1 \mathrm{H}), 7.88$ (dd, $J=8.6,2.5 \mathrm{~Hz}, 1 \mathrm{H}), 7.73(\mathrm{~d}, J=8.6 \mathrm{~Hz}, 1 \mathrm{H}), 7.40(\mathrm{~s}$, $1 \mathrm{H}), 7.18$ (d, $J=8.2 \mathrm{~Hz}, 2 \mathrm{H}), 6.91-6.86(\mathrm{dd}, 2 \mathrm{H}), 6.83$ (s, $1 \mathrm{H}), 5.50(\mathrm{~d}, J=5.6 \mathrm{~Hz}, 1 \mathrm{H}), 4.35(\mathrm{dd}, J=13.4,3.6 \mathrm{~Hz}, 1 \mathrm{H})$, $4.18(\mathrm{~m}, 1 \mathrm{H}), 4.02-3.84(\mathrm{~m}, 3 \mathrm{H}), 3.30(\mathrm{~s}, 2 \mathrm{H}) .{ }^{13} \mathrm{C} \mathrm{NMR}$ $\left(101 \mathrm{MHz}, \mathrm{DMSO}-d_{6}\right) \delta 173.00,159.98,157.46,149.74$, $147.24,134.87,131.64,130.52$, 130.52, 129.92, 129.26, 125.50, 123.33, 114.76, 114.76, 70.68, 66.51, 50.07, 41.82. LCMS $m / z$ calc for $\mathrm{C}_{19} \mathrm{H}_{19} \mathrm{ClN}_{3} \mathrm{O}_{4}^{+}[\mathrm{M}+\mathrm{H}]^{+}$: 388.1, found 387.9.

2-(4-(3-(6-Chloro-4-oxoquinazolin-3(4H)-yl)-2-hydroxypropoxy)phenyl)acetic acid 60. A suspension of 22 (0.1 g, $0.27 \mathrm{mmol})$ in water $(5 \mathrm{~mL})$ and $\mathrm{HCl}(1 \mathrm{~mL}, 10.8)$ was stirred at $75{ }^{\circ} \mathrm{C}$ for $18 \mathrm{~h}$. Afterward, the reaction was treated with saturated $\mathrm{NaHCO}_{3}$ and then extracted with EtOAc $(20 \mathrm{~mL})$. The aqueous layer was then acidified with $\mathrm{HCl}(36 \%)$, and the resulting solid was filtered and used without further purification. Off white solid (46 mg, 44\%). ${ }^{1} \mathrm{H}$ NMR (400 MHz, DMSO- $\left.d_{6}\right) \delta 12.2$ (br S, $\left.1 \mathrm{H}\right), 8.32(\mathrm{~S}, 1 \mathrm{H}), 8.23$ (d, $J=$ $2.2 \mathrm{~Hz}, 1 \mathrm{H}), 7.71(\mathrm{dd}, J=7.4,2.1 \mathrm{~Hz}, 1 \mathrm{H}), 7.52(\mathrm{~d}, J=7.5 \mathrm{~Hz}$, $1 \mathrm{H}), 7.21-7.13(\mathrm{~m}, 2 \mathrm{H}), 6.89-6.81(\mathrm{~m}, 2 \mathrm{H}), 5.07(\mathrm{~d}, J=5.0$ $\mathrm{Hz}, 1 \mathrm{H}), 4.91-4.81(\mathrm{~m}, 1 \mathrm{H}), 4.23(\mathrm{dd}, J=12.4,1.7 \mathrm{~Hz}, 1 \mathrm{H})$, $4.10(\mathrm{dd}, J=12.4,4.9 \mathrm{~Hz}, 1 \mathrm{H}), 3.82(\mathrm{dd}, J=12.5,9.9 \mathrm{~Hz}$, $1 \mathrm{H}), 3.77-3.67(\mathrm{~m}, 1 \mathrm{H}), 3.60-3.43(\mathrm{~m}, 2 \mathrm{H}) .{ }^{13} \mathrm{C}$ NMR (101 MHz, DMSO- $\left.d_{6}\right) \delta 174.89,159.87,156.72,150.16,148.43$, 133.56, 128.83, 127.11, 114.64, 71.22, 67.18, 50.16, 42.50. LCMS $m / z$ calc for $\mathrm{C}_{19} \mathrm{H}_{17} \mathrm{ClN}_{2} \mathrm{O}_{5}^{+}[\mathrm{M}+\mathrm{H}]^{+}: 389.1$, found 388.8 .

General Procedure (6) for Preparation of 61-62. To a stirred solution of 2-(4-hydroxyphenyl)acetonitrile (1 g, 5.3 $\mathrm{mmol}$ ) in $100 \mathrm{~mL} \mathrm{MeCN}$ was added $\mathrm{Cs}_{2} \mathrm{CO}_{3}$ (3.3 g, 10.6 $\mathrm{mmol}$ ) and either $(R)$-oxiran-2-ylmethyl 3-nitrobenzenesulfonate Or $(S)$-oxiran-2-ylmethyl 3-nitrobenzenesulfonate $(1.7 \mathrm{~g}, 6.4 \mathrm{mmol})$, and the mixture was refluxed for $18 \mathrm{~h}$. Subsequently, the reaction mixture was filtered and concentrated. The residue was purified using PE:EtOAc 9:1 as an eluent. Either (R)-2-(4-(oxiran-2-ylmethoxy)phenyl)acetonitrile or (S)-2-(4-(oxiran-2-ylmethoxy)phenyl)acetonitrile $(0.5 \mathrm{~g}, 3 \mathrm{mmol})$ was further reacted with $2(0.47$ $\mathrm{g}, 2.6 \mathrm{mmol})$ in the presence of $\mathrm{Cs}_{2} \mathrm{CO}_{3}(1.7 \mathrm{~g}, 5.2 \mathrm{mmol})$ and TBAI $(110 \mathrm{mg}, 0.3 \mathrm{mmol})$ according to general procedure 2 .

(R)-2-(4-(3-(6-Chloro-4-oxoquinazolin-3(4H)-yl)-2hydroxypropoxy)phenyl)acetonitrile 61 . White solid (0.56 g, $59 \%) .{ }^{1} \mathrm{H}$ NMR (400 MHz, DMSO-d $)_{6} \delta 8.32$ (s, 1H), 8.08 $(\mathrm{d}, J=2.3 \mathrm{~Hz}, 1 \mathrm{H}), 7.91(\mathrm{dd}, J=8.7,2.3 \mathrm{~Hz}, 1 \mathrm{H}), 7.71(\mathrm{~d}, J=$ $8.7 \mathrm{~Hz}, 1 \mathrm{H}), 7.24(\mathrm{~d}, J=8.2 \mathrm{~Hz}, 2 \mathrm{H}), 6.89(\mathrm{~d}, J=8.3 \mathrm{~Hz}, 2 \mathrm{H})$, $5.51(\mathrm{~d}, J=5.6 \mathrm{~Hz}, 1 \mathrm{H}), 4.33(\mathrm{dd}, J=13.5,3.6 \mathrm{~Hz}, 1 \mathrm{H}), 4.17$ $(\mathrm{m}, 1 \mathrm{H}), 4.12-3.94(\mathrm{~m}, 2 \mathrm{H}), 3.94(\mathrm{~s}, 2 \mathrm{H}), 3.94-3.86(\mathrm{~m}$, 1H). ${ }^{13} \mathrm{C}$ NMR (101 MHz, DMSO-d $) \delta 159.48,158.50$, 149.61, 147.28, 134.89, 131.63, 129.91, 129.78, 125.57, 123.78, 123.39, 119.99, 115.48, 70.72, 66.98, 50.32, 22.01. LCMS calculated for $\mathrm{C}_{19} \mathrm{H}_{17} \mathrm{ClN}_{3} \mathrm{O}_{3}{ }^{+}[\mathrm{M}+\mathrm{H}]^{+}: 370.1$ found 370.5, HRMS calculated for $\mathrm{C}_{19} \mathrm{H}_{17} \mathrm{ClN}_{3} \mathrm{O}_{3}{ }^{+}[\mathrm{M}+\mathrm{H}]^{+}: 370.0953$ found 370.0950 .

(S)-2-(4-(3-(6-Chloro-4-oxoquinazolin-3(4H)-yl)-2hydroxypropoxy)phenyl)acetonitrile 62 . White solid (0.53 g, 54\%). ${ }^{1} \mathrm{H}$ NMR (400 MHz, DMSO-d 6 ) $\delta 8.31(\mathrm{~s}, 1 \mathrm{H}), 8.10$ $(\mathrm{d}, J=2.4 \mathrm{~Hz}, 1 \mathrm{H}), 7.86(\mathrm{dd}, J=8.7,2.5 \mathrm{~Hz}, 1 \mathrm{H}), 7.72(\mathrm{~d}, J=$ $8.7 \mathrm{~Hz}, 1 \mathrm{H}), 7.26$ (d, $J=8.2 \mathrm{~Hz}, 2 \mathrm{H}), 6.96(\mathrm{~d}, J=8.3 \mathrm{~Hz}, 2 \mathrm{H})$, $5.51(\mathrm{~d}, J=5.6 \mathrm{~Hz}, 1 \mathrm{H}), 4.33(\mathrm{dd}, J=13.5,3.7 \mathrm{~Hz}, 1 \mathrm{H}), 4.17$ (m, 1H), 4.11-3.94 (m, 2H), $3.94(\mathrm{~s}, 2 \mathrm{H}), 3.94-3.86(\mathrm{~m}$, $1 \mathrm{H}) .{ }^{13} \mathrm{C}$ NMR (101 MHz, DMSO-d $d_{6} \delta 159.98,158.30$, $149.71,147.23,134.86,131.63,129.91,129.78,125.49,123.78$, 123.34, 119.99, 115.48, 70.72, 66.47, 50.02, 22.01. LCMS calculated for $\mathrm{C}_{19} \mathrm{H}_{17} \mathrm{ClN}_{3} \mathrm{O}_{3}{ }^{+}[\mathrm{M}+\mathrm{H}]^{+}: 370.1$ found 370.2, HRMS calculated for $\mathrm{C}_{19} \mathrm{H}_{17} \mathrm{ClN}_{3} \mathrm{O}_{3}{ }^{+}[\mathrm{M}+\mathrm{H}]^{+}: 370.0953$ found 370.0955 .

Bacterial Strains and Growth Conditions. The $P$. aeruginosa strains and plasmids used in this study are shown in Table 4. Bacteria were grown in lysogeny broth (LB) at 37 ${ }^{\circ} \mathrm{C}$, unless stated otherwise. Where required, tetracycline (Tc) was added to the media at $125 \mu \mathrm{g} / \mathrm{mL}$, to select for recombinants. Synthetic alkylquinolones were added at the concentrations indicated.

Biosensor Reporter Assay. Strains PA14 mCTX::P $\mathrm{P}_{p q A^{-}}$ $l u x$ and PAO1-L mCTX::P $P_{p q s}-l u x$ were constructed using plasmid mini-CTX:: $\mathrm{P}_{p q s}-l u x$, as previously described, ${ }^{50}$ and the assay was performed according to a published method. ${ }^{52}$ For initial screening, the compounds were tested at a concentration of $10 \mu \mathrm{M}$, which was prepared from a $10 \mathrm{mM}$ stock, in DMSO.

Isothermal Titration Calorimetry (ITC). PqsR ${ }^{94-332}$ $\left(\mathrm{PqsR}^{\mathrm{LBD}}\right.$ ) was prepared by Ni-NTA (HisTrap HP) followed by gel filtration with a Superdex 75 16/60 and flash frozen in liquid nitrogen until required. For ITC, the sample was thawed, clarified by centrifugation, and dialyzed overnight against a buffer of $50 \mathrm{mM}$ tricine- $\mathrm{NaOH}(\mathrm{pH}=8.5), 250 \mathrm{mM}$ $\mathrm{NaCl}, 5 \%$ glycerol. The sample was quantified by A280 using an extinction coefficient of $22920 \mathrm{M}^{-1} \mathrm{~cm}^{-1}$. The sample was diluted to $10 \mu \mathrm{M}$. Compound 61 was dissolved in DMSO and diluted into assay buffer to $100 \mu \mathrm{M}$. An appropriate amount of DMSO was added to the sample to prevent mismatch. ITC measurements were conducted on a MicroCal PEAQ ITC 
instrument using a sample volume of $280 \mu \mathrm{L}$ with 19 ligand injections of $2 \mu \mathrm{L}$. The cell temperature was kept at $25{ }^{\circ} \mathrm{C}$ and stirring was carried out as $750 \mathrm{rpm}$. Reference power was set to $6 \mathrm{DP}$ with spacing kept at $180 \mathrm{~s}$. The same procedure was carried out for the T265A mutant. Mutants were prepared using the site directed mutagenesis protocol from Agilent and the primer sequences: 5'-GCGGCATCGACGCGAAGGTGTATTGC-3' and 5'-GCAATACACCTTEGCGTCGATGCCGC-3'.

Protein Expression and Crystallization. Crystallization and structural solution was performed as previously described. ${ }^{18,19}$

Pyocyanin Quantification. The experiment was performed following a published protocol with minor modifications. ${ }^{53}$ PA strains were cultured into $5 \mathrm{~mL}$ fresh medium overnight. Compounds were assayed at $3 \times \mathrm{IC}_{50}$ s concentration, for $16 \mathrm{~h}$, at $37{ }^{\circ} \mathrm{C}$ (Kuhner LT W Shaker, Adolf Kühner AG, Basel, Switzerland). Cells were centrifuged at $10000 \mathrm{RCF}$ for $10 \mathrm{~min}$ (Allegra 64R centrifuge, Beckman Coulter, High Wycombe, UK), and the supernatant was transferred to $15 \mathrm{~mL}$ falcon tubes with a HSW $10 \mathrm{~mL}$ Soft-Ject Syringe and a $0.22 \mu \mathrm{M}$ Sartorius syringe-driven filter (Fisher Brand, Loughborough, UK). Pyocyanin pigment was extracted into chloroform by mixing $7.5 \mathrm{~mL}$ of supernatant with $4.5 \mathrm{~mL}$ of chloroform. Pyocyanin was further extracted into $1.5 \mathrm{~mL}$ of $0.2 \mathrm{M} \mathrm{HCL}$, which gave a pink/red solution, and the absorbance was measured at $520 \mathrm{~nm}$.

LCMS-MS Alkyl Quinoline Quantification. For each test sample, $100 \mu \mathrm{L}$ of sterile filtered supernatant (the same preparation as for pyocyanin using the following concentrations: PAO1-L $3 \mu \mathrm{M}$, PA14 $3 \mu \mathrm{M}$, PA7-48 $15 \mu \mathrm{M}$, LESB58 $5 \mu \mathrm{M}$, and PAK6085 $9 \mu \mathrm{M}$ ) was spiked with $10 \mu \mathrm{L}$ of an internal standard solution (10 $\mu \mathrm{M}$ d4-PQS in $\mathrm{MeOH})$ and diluted with water, to a total volume of $500 \mu \mathrm{L}$. Samples were then extracted three times with an $0.5 \mathrm{~mL}$ aliquot of ethyl acetate, vortex mixing the aqueous/organic mix for $2 \mathrm{~min}$, then removing the organic phase once the layers had successfully partitioned. For each sample, the combined organic extracts were dried under vacuum and redissolved in $100 \mu \mathrm{L} \mathrm{MeOH}$ prior to analysis. For the LC-MS/MS analysis of supernatant extracts, the chromatography was achieved using a Shimadzu series 10AD VP LC system (Columbia, MD, USA). The LC column, maintained at $40{ }^{\circ} \mathrm{C}$, was a Phenomenex Gemini C18 $(3.0 \mu \mathrm{m}, 100 \times 3.0 \mathrm{~mm})($ Macclesfield, Cheshire, UK) with an appropriate guard column. Mobile phase A was $0.1 \%(v / v)$ formic acid in water containing $2 \mathrm{mM}$ 2-picolinic acid, and mobile phase B $0.1 \%(v / v)$ formic acid in methanol. The flow rate throughout the chromatographic separation was $450 \mu \mathrm{L} /$ min. After an injection of a $2 \mu \mathrm{L} /$ sample, a binary gradient, beginning initially at $30 \% \mathrm{~B}$, increased linearly to $99 \%$ B over 5 min. The composition remained at $99 \%$ B for 3 min, decreased to $30 \% \mathrm{~B}$ over $1 \mathrm{~min}$, and stayed at this composition for $4 \mathrm{~min}$, to allow for column equilibration. The MS system used for analyte detection was an Applied Biosystems Qtrap 4000 hybrid triple-quadrupole linear ion trap mass spectrometer (Foster City, CA, USA), equipped with an electrospray ionization (ESI) interface. Instrument control, data collection and analysis were conducted using Analyst software (Foster City, CA, USA). The MS analysis was achieved with positive electrospray (+ES) multiple reaction monitoring (MRM) screening of the LC eluent for specific AQ analytes. Where chromatographic peaks for HHQ HQNO, and PQS were detected, a peak area was determined, and analyte peak area/ internal standard peak area calculated.

Biofilm Assay Methodology. Mature $P$. aeruginosa biofilms were used to characterize the effect of ciprofloxacin and QSI treatment combinations. Biofilms were grown on round glass coverslips ( $8 \mathrm{~mm}$, no. 1.5 thickness) under flow conditions $(20 \mathrm{rpm})$ in FAB $10 \mathrm{mM}$ glucose medium ${ }^{54}$ with or without supplementation of $61(10 \mu \mathrm{M})$, inoculated with diluted (OD600 $\mathrm{nm}=0.01$ ) bacteria from overnight cultures in LB. ${ }^{44}$ Biofilms were cultivated at $30{ }^{\circ} \mathrm{C}$ for 2 days with medium replacement after $24 \mathrm{~h}$ incubation. At this time, biofilms were washed in PBS to remove loosely attached cells and incubated for further $5 / 24 \mathrm{~h}$ in fresh medium supplemented with various treatments. These included free ciprofloxacin $60 \mu \mathrm{g} / \mathrm{mL}$, compound 61 at $10 \mu \mathrm{M}$, and ciprofloxacin in combination with 61. Biofilms exposed to each treatment at the indicated concentrations were washed in PBS and the viability of attached cells evaluated by fluorescent staining with the LIVE/DEAD BacLight bacterial viability kit (Molecular Probes, Life Technologies) according to manufacturer instructions. Following staining, coverslips were rinsed with distilled water and imaged using a LSM700 AxioObserver (Carl Zeiss, Germany) confocal laser scanning microscope (CLSM). Viable and nonviable biofilm biomass quantification from image stacks of biofilms was done with Fiji-ImageJ software. Live/dead ratios were established for each treatment and compared to untreated controls.

Galleria mellonella Survival Assay. Antibiotic free Galleria mellonella were purchased from Livefoods Direct Ltd. (Sheffield, UK) maintained at room temperature in the dark and used within 3 days. Larvae were selected in the final (7th) instar and were randomly assigned to groups after weighing $\sim 250 \mathrm{mg}$. Ten larvae were assigned to each grouping in $9 \mathrm{~cm}$ Petri dishes: Sham (injection, no infection), injection (PBS), DMSO only (DMSO) inoculation only (PA), inoculation plus ciprofloxacin $(\mathrm{PA}+\mathrm{CIP})$, inoculation plus $61(\mathrm{PA}+61)$ and inoculation plus ciprofloxacin and $61(\mathrm{PA}+$ $\mathrm{CIP}+61)$. The PA strains PAO1-N and PAO1-L were selected as these give differing rates of mortality, chronic-like and acutelike respectively. An inoculum was prepared separately for each grouping at a final size of $1 \times 10^{4} \mathrm{CFU} / \mathrm{mL}$. The addition of the quorum sensing inhibitor 61 was performed prior to inoculation to a final concentration of $10 \mu \mathrm{M}$. Inoculation of wax worms was performed using a $50 \mu \mathrm{L}$ Hamilton syringe (Fisher, Leicestershire, UK) with 29 G $0.5 \mathrm{~mm}$ needle attachment (Becton Dickinson U.K. ltd, Oxford, UK), briefly $10 \mu \mathrm{L}$ of inoculum was injected into the rear most left pro-leg of the larvae. To the rear most right pro-leg, $10 \mu \mathrm{L}$ of 0.025 $\mu \mathrm{g} / \mathrm{mL}$ CIP treatment was injected post inoculum for Cip treated wax worms. Wax worm larvae were incubated at $37^{\circ} \mathrm{C}$ in the dark. Larvae were monitored hourly and death event recorded when no movement was observed and no response to mechanical stimulus was elicited.

Cytotoxicity Assay. The human carcinoma lung epithelial cells A549 (ATCC CCL-185) are grown at $37{ }^{\circ} \mathrm{C}$ in $5 \% \mathrm{CO}_{2}$ for $24 \mathrm{~h}$ in RPMI medium. A cell concentration of $1 \times 10^{4}$ cells $/ \mathrm{mL}$ was used and dispensed in 96 well plates $(100 \mu \mathrm{L}$ in each well). A serial dilution of $\mathbf{6 1}$ was then prepared in growth media and added to the plate in triplicate. Potassium dichromate at $100 \mu \mathrm{M}$ was used as positive control, and a solvent vehicle control was prepared as negative control. Cells were then incubated for a further $16 \mathrm{~h}$, and $20 \mu \mathrm{L}$ of Alamar blue added to each well. After $5 \mathrm{~h}$ incubation, fluorescence was 
measured with excitation at $510 \mathrm{~nm}$ and emission at $590 \mathrm{~nm}$. Values were then normalized against the untreated control. ${ }^{55}$

Data Management and Analysis. Instant JChem was used for structure database management, Search and Prediction, Instant JChem 16.2.15.0 2016, ChemAxon (http://www. chemaxon.com).

Sigmoidal dose-response curves and the representation of all data were prepared using GraphPad Prism 9.0.2.

\section{ASSOCIATED CONTENT}

\section{SI Supporting Information}

The Supporting Information is available free of charge at https://pubs.acs.org/doi/10.1021/acsinfecdis.1c00175.

Structures and activities of commercial analogues of 22, representative isotherm generated from injection of $\mathbf{6 1}$ into the T265A PqsR mutant construct, and crystallographic data collection and refinement statistics (PDF)

Special Issue Paper

Published as part of the Antibiotic Alternatives special issue.

\section{AUTHOR INFORMATION}

\section{Corresponding Authors}

Michael J. Stocks - School of Pharmacy, University of Nottingham Biodiscovery Institute and The National Biofilms Innovation Centre, University of Nottingham Biodiscovery Institute, University of Nottingham, Nottingham NG7 2RD, U.K.; (1) orcid.org/0000-0003-3046-137X;

Email: michael.stocks@nottingham.ac.uk

Miguel Cámara - School of Life Sciences, University of Nottingham Biodiscovery Institute and The National Biofilms Innovation Centre, University of Nottingham Biodiscovery Institute, University of Nottingham, Nottingham NG7 2RD, U.K.; Email: miguel.camara@nottingham.ac.uk

\section{Authors}

Fadi Soukarieh - School of Life Sciences, University of Nottingham Biodiscovery Institute and The National Biofilms Innovation Centre, University of Nottingham Biodiscovery Institute, University of Nottingham, Nottingham NG7 2RD, U.K.; (1) orcid.org/0000-0002-6730-2543

Alaa Mashabi - School of Pharmacy, University of Nottingham Biodiscovery Institute, University of Nottingham, Nottingham NG7 2RD, U.K.

William Richardson - School of Pharmacy, University of Nottingham Biodiscovery Institute, University of Nottingham, Nottingham NG7 2RD, U.K.

Eduard Vico Oton - School of Life Sciences, University of Nottingham Biodiscovery Institute, University of Nottingham, Nottingham NG7 2RD, U.K.; Present Address: E.V.O.: Environmental Microbiology Laboratoy, École polytechnique fédérale de Lausanne, CH-1015, Lausanne, Switzerland

Manuel Romero - School of Life Sciences, University of Nottingham Biodiscovery Institute and The National Biofilms Innovation Centre, University of Nottingham Biodiscovery Institute, University of Nottingham, Nottingham NG7 2RD, U.K.

Shaun N. Roberston - School of Life Sciences, University of Nottingham Biodiscovery Institute and The National Biofilms Innovation Centre, University of Nottingham Biodiscovery Institute, University of Nottingham, Nottingham NG7 2RD, U.K.
Scott Grossman - School of Pharmacy, University of Nottingham Biodiscovery Institute, University of Nottingham, Nottingham NG7 2RD, U.K.

Tomas Sou - Department of Pharmacy, Uppsala University, Uppsala SE-751 23, Sweden

Ruiling Liu - School of Pharmacy, University of Nottingham Biodiscovery Institute, University of Nottingham, Nottingham NG7 2RD, U.K.

Nigel Halliday - School of Life Sciences, University of Nottingham Biodiscovery Institute, University of Nottingham, Nottingham NG7 2RD, U.K.

Irena Kukavica-Ibrulj - Institut de Biologie Integrative et des Systemes, Universite Laval, Quebec G1 V 0A6, Canada

Roger C. Levesque - Institut de Biologie Integrative et des Systemes, Universite Laval, Quebec G1 V 0A6, Canada

Christel A. S. Bergstrom - Department of Pharmacy, Uppsala University, Uppsala SE-751 23, Sweden

Barrie Kellam - School of Pharmacy, University of Nottingham Biodiscovery Institute, University of Nottingham, Nottingham NG7 2RD, U.K.; (1) orcid.org/0000-00030030-9908

Jonas Emsley - School of Pharmacy, University of Nottingham Biodiscovery Institute and The National Biofilms Innovation Centre, University of Nottingham Biodiscovery Institute, University of Nottingham, Nottingham NG7 2RD, U.K.

Stephan Heeb - School of Life Sciences, University of Nottingham Biodiscovery Institute, University of Nottingham, Nottingham NG7 2RD, U.K.

Paul Williams - School of Life Sciences, University of Nottingham Biodiscovery Institute and The National Biofilms Innovation Centre, University of Nottingham Biodiscovery Institute, University of Nottingham, Nottingham NG7 2RD, U.K.

Complete contact information is available at:

https://pubs.acs.org/10.1021/acsinfecdis.1c00175

\section{Author Contributions}

F.S. and A.M. contributed equally to this work. F.S. performed in silico and in vitro screening, designed and performed syntheses directed the microbiology experiments. A.M. performed syntheses, microbiology experiments, and contributed to writing. F.S., M.S., P.W., and M.C. designed and supervised the study and led the writing of the manuscript. E.V.O., M.R., S.N.R., S.G., R.L., and N.H. performed the experimental microbiology. W.R. and J.E. performed and designed crystallography and ITC experiments. B.K., R.L., S.H., T.S., C.A.S.B., I.K.-I., and R.C.L. contributed to experimental design. We also thank Jeff Gauthier for his support in performing sequence alignment.

\section{Funding}

This work was supported by the Engineering and Physical Sciences Research Council [grant numbers EP/N006615/1 and EP/K005138/1, EP/N03371X/1] and JPI-AMR and MRC for funding the SENBIOTAR program (ref. MR/ N501852/1). F.S., M.R., S.N.R., P.W., M.J.S., J.E., and M.C. are funded by the National Biofilms Innovation Centre (NBIC) which is an Innovation and Knowledge Centre funded by the Biotechnology and Biological Sciences Research Council, InnovateUK and Hartree Centre [Award Number BB/R012415/1]. S.G. and W.R. are funded via the Wellcome 
Trust doctoral training program in antimicrobials and antimicrobial resistance (ref: 108876/B/15/Z).

\section{Notes}

The authors declare no competing financial interest.

\section{REFERENCES}

(1) Cassini, A., Hogberg, L. D., Plachouras, D., Quattrocchi, A., Hoxha, A., Simonsen, G. S., Colomb-Cotinat, M., Kretzschmar, M. E., Devleesschauwer, B., Cecchini, M., Ouakrim, D. A., Oliveira, T. C., Struelens, M. J., Suetens, C., Monnet, D. L., et al. (2019) Attributable deaths and disability-adjusted life-years caused by infections with antibiotic-resistant bacteria in the EU and the European Economic Area in 2015: a population-level modelling analysis. Lancet Infect. Dis. 19, 56-66.

(2) Pew Trusts. Antibiotics Currently in Global Clinical Development. https://www.pewtrusts.org/en/research-and-analysis/datavisualizations/2014/antibiotics-currently-in-clinical-development (accessed March 15, 2021).

(3) World Health Organisation. (2017) Guidelines for the prevention and control of carbapenem-resistant Enterobacteriaceae, Acinetobacter baumannii and Pseudomonas aeruginosa in health care facilities.

(4) Obritsch, M. D., Fish, D. N., MacLaren, R., and Jung, R. (2005) Nosocomial infections due to multidrug-resistant Pseudomonas aeruginosa: epidemiology and treatment options. Pharmacotherapy $25,1353-1364$

(5) Muhlen, S., and Dersch, P. (2015) Anti-virulence Strategies to Target Bacterial Infections. Curr. Top. Microbiol. Immunol. 398, 147183.

(6) Theuretzbacher, U., Outterson, K., Engel, A., and Karlen, A. (2020) The global preclinical antibacterial pipeline. Nat. Rev. Microbiol. 18, 275-285.

(7) Soukarieh, F., Williams, P., Stocks, M. J., and Cámara, M. (2018) Pseudomonas aeruginosa Quorum Sensing Systems as Drug Discovery Targets: Current Position and Future Perspectives. J. Med. Chem. 61, 10385-10402.

(8) Ellermann, M., and Sperandio, V. (2020) Bacterial signaling as an antimicrobial target. Curr. Opin. Microbiol. 57, 78-86.

(9) Lee, J., and Zhang, L. (2015) The hierarchy quorum sensing network in Pseudomonas aeruginosa. Protein Cell 6, 26-41.

(10) Ng, W. L., and Bassler, B. L. (2009) Bacterial quorum-sensing network architectures. Annu. Rev. Genet. 43, 197-222.

(11) Williams, P., and Cámara, M. (2009) Quorum sensing and environmental adaptation in Pseudomonas aeruginosa: a tale of regulatory networks and multifunctional signal molecules. Curr. Opin. Microbiol. 12, 182-191.

(12) Welsh, M. A., and Blackwell, H. E. (2016) Chemical Genetics Reveals Environment-Specific Roles for Quorum Sensing Circuits in Pseudomonas aeruginosa. Cell Chem. Biol. 23, 361-9.

(13) Rampioni, G., Falcone, M., Heeb, S., Frangipani, E., Fletcher, M. P., Dubern, J. F., Visca, P., Leoni, L., Camara, M., and Williams, P. (2016) Unravelling the Genome-Wide Contributions of Specific 2Alkyl-4-Quinolones and PqsE to Quorum Sensing in Pseudomonas aeruginosa. PLoS Pathog. 12, No. e1006029.

(14) García-Reyes, S., Soberón-Chávez, G., and Cocotl-Yanez, M. (2020) The third quorum-sensing system of Pseudomonas aeruginosa: Pseudomonas quinolone signal and the enigmatic PqsE protein. $J$. Med. Microbiol. 69, 25-34.

(15) Zhou, Z., and Ma, S. (2017) Recent Advances in the Discovery of PqsD Inhibitors as Antimicrobial Agents. ChemMedChem 12, 420425.

(16) Ji, C., Sharma, I., Pratihar, D., Hudson, L. L., Maura, D., Guney, T., Rahme, L. G., Pesci, E. C., Coleman, J. P., and Tan, D. S. (2016) Designed Small-Molecule Inhibitors of the Anthranilyl-CoA Synthetase PqsA Block Quinolone Biosynthesis in Pseudomonas aeruginosa. ACS Chem. Biol. 11, 3061-3067.

(17) Soheili, V., Tajani, A. S., Ghodsi, R., and Bazzaz, B. S. F. (2019) Anti-PqsR compounds as next-generation antibacterial agents against Pseudomonas aeruginosa: A review. Eur. J. Med. Chem. 172, 26-35.
(18) Soukarieh, F., Liu, R., Romero, M., Roberston, S. N., Richardson, W., Lucanto, S., Oton, E. V., Qudus, N. R., Mashabi, A., Grossman, S., Ali, S., Sou, T., Kukavica-Ibrulj, I., Levesque, R. C., Bergstrom, C. A. S., Halliday, N., Mistry, S. N., Emsley, J., Heeb, S., Williams, P., Camara, M., and Stocks, M. J. (2020) Hit Identification of New Potent PqsR Antagonists as Inhibitors of Quorum Sensing in Planktonic and Biofilm Grown Pseudomonas aeruginosa. Front. Chem. $8,204$.

(19) Grossman, S., Soukarieh, F., Richardson, W., Liu, R., Mashabi, A., Emsley, J., Williams, P., Cámara, M., and Stocks, M. J. (2020) Novel quinazolinone inhibitors of the Pseudomonas aeruginosa quorum sensing transcriptional regulator PqsR. Eur. J. Med. Chem. 208, 112778.

(20) Friesner, R. A., Murphy, R. B., Repasky, M. P., Frye, L. L., Greenwood, J. R., Halgren, T. A., Sanschagrin, P. C., and Mainz, D. T. (2006) Extra Precision Glide: Docking and Scoring Incorporating a Model of Hydrophobic Enclosure for Protein-Ligand Complexes. J. Med. Chem. 49, 6177-6196.

(21) Friesner, R. A., Banks, J. L., Murphy, R. B., Halgren, T. A., Klicic, J. J., Mainz, D. T., Repasky, M. P., Knoll, E. H., Shelley, M., Perry, J. K., Shaw, D. E., Francis, P., and Shenkin, P. S. (2004) Glide: A New Approach for Rapid, Accurate Docking and Scoring. 1. Method and Assessment of Docking Accuracy. J. Med. Chem. 47, $1739-1749$.

(22) Venkatesh, R., Kasaboina, S., Gaikwad, H. K., Janardhan, S., Bantu, R., Nagarapu, L., Sastry, G. N., and Banerjee, S. K. (2015) Design and synthesis of 3-(3-((9H-carbazol-4-yl)oxy)-2-hydroxypropyl)-2-phenylquinazolin-4 $(3 \mathrm{H})$-one derivatives to induce ACE inhibitory activity. Eur. J. Med. Chem. 96, 22-9.

(23) Foss, F. W., Jr., Snyder, A. H., Davis, M. D., Rouse, M., Okusa, M. D., Lynch, K. R., and Macdonald, T. L. (2007) Synthesis and biological evaluation of gamma-aminophosphonates as potent, subtype-selective sphingosine 1-phosphate receptor agonists and antagonists. Bioorg. Med. Chem. 15, 663-77.

(24) Zhou, D., Hatzenbuhler, N. T., Gross, J. L., Harrison, B. L., Evrard, D. A., Chlenov, M., Golembieski, J., Hornby, G., Schechter, L. E., Smith, D. L., Andree, T. H., and Stack, G. P. (2007) Novel pyridylfused 3-amino chroman derivatives with dual action at serotonin transporter and 5-HT1A receptor. Bioorg. Med. Chem. Lett. 17, 311721.

(25) Bjorklund, C., Adolfsson, H., Jansson, K., Lindberg, J., Vrang, L., Hallberg, A., Rosenquist, S., and Samuelsson, B. (2010) Discovery of potent BACE-1 inhibitors containing a new hydroxyethylene (HE) scaffold: exploration of $\mathrm{P} 1^{\prime}$ alkoxy residues and an aminoethylene (AE) central core. Bioorg. Med. Chem. 18, 1711-23.

(26) Heravi, M. M., Momeni, T., Zadsirjan, V., and Mohammadi, L. (2021) Application of The Dess-Martin Oxidation in Total Synthesis of Natural Products. Curr. Org. Synth. 18, 125-196.

(27) Shellhamer, D. F., Briggs, A. A., Miller, B. M., Prince, J. M., Scott, D. H., and Heasley, V. L. (1996) Reaction of aminosulfur trifluorides with alcohols: inversion vs. retention. J. Chem. Soc., Perkin Trans. 2, 973-977.

(28) Baykov, S., Sharonova, T., Shetnev, A., Rozhkov, S., Kalinin, S., and Smirnov, A. V. (2017) The first one-pot ambient-temperature synthesis of 1,2,4-oxadiazoles from amidoximes and carboxylic acid esters. Tetrahedron 73, 945-951.

(29) Myznikov, L. V., Roh, J., Artamonova, T. V., Hrabalek, A., and Koldobskii, G. I. (2007) Tetrazoles: LI. Synthesis of 5-substituted tetrazoles under microwave activation. Russ. J. Org. Chem. 43, 765767.

(30) Katritzky, A. R., Pilarski, B., and Urogdi, L. (1989) Efficient Conversion of Nitriles to Amides with Basic Hydrogen Peroxide in Dimethyl Sulfoxide. Synthesis 1989, 949-950.

(31) Zhang, C., Pei, H., He, J., Zhu, J., Li, W., Niu, T., Xiang, M., and Chen, L. (2019) Design, synthesis and evaluation of novel $7 \mathrm{H}$ pyrrolo[2,3-d]pyrimidin-4-amine derivatives as potent, selective and reversible Bruton's tyrosine kinase (BTK) inhibitors for the treatment of rheumatoid arthritis. Eur. J. Med. Chem. 169, 121-143. 
(32) Ilangovan, A., Fletcher, M., Rampioni, G., Pustelny, C., Rumbaugh, K., Heeb, S., Camara, M., Truman, A., Chhabra, S. R., Emsley, J., and Williams, P. (2013) Structural basis for native agonist and synthetic inhibitor recognition by the Pseudomonas aeruginosa quorum sensing regulator PqsR (MvfR). PLoS Pathog. 9, No. e1003508.

(33) Jayaseelan, S., Ramaswamy, D., and Dharmaraj, S. (2014) Pyocyanin: production, applications, challenges and new insights. World J. Microbiol. Biotechnol. 30, 1159-68.

(34) Hall, S., McDermott, C., Anoopkumar-Dukie, S., McFarland, A. J., Forbes, A., Perkins, A. V., Davey, A. K., Chess-Williams, R., Kiefel, M. J., Arora, D., and Grant, G. D. (2016) Cellular Effects of Pyocyanin, a Secreted Virulence Factor of Pseudomonas aeruginosa. Toxins 8, 236.

(35) Higgins, S., Heeb, S., Rampioni, G., Fletcher, M. P., Williams, P., and Cámara, M. (2018) Differential Regulation of the Phenazine Biosynthetic Operons by Quorum Sensing in Pseudomonas aeruginosa PAO1-N. Front. Cell. Infect. Microbiol., DOI: 10.3389/ fcimb.2018.00252.

(36) Freschi, L., Jeukens, J., Kukavica-Ibrulj, I., Boyle, B., Dupont, M. J., Laroche, J., Larose, S., Maaroufi, H., Fothergill, J. L., Moore, M., Winsor, G. L., Aaron, S. D., Barbeau, J., Bell, S. C., Burns, J. L., Camara, M., Cantin, A., Charette, S. J., Dewar, K., Deziel, E., Grimwood, K., Hancock, R. E., Harrison, J. J., Heeb, S., Jelsbak, L., Jia, B., Kenna, D. T., Kidd, T. J., Klockgether, J., Lam, J. S., Lamont, I. L., Lewenza, S., Loman, N., Malouin, F., Manos, J., McArthur, A. G., McKeown, J., Milot, J., Naghra, H., Nguyen, D., Pereira, S. K., Perron, G. G., Pirnay, J. P., Rainey, P. B., Rousseau, S., Santos, P. M., Stephenson, A., Taylor, V., Turton, J. F., Waglechner, N., Williams, P., Thrane, S. W., Wright, G. D., Brinkman, F. S., Tucker, N. P., Tummler, B., Winstanley, C., and Levesque, R. C. (2015) Clinical utilization of genomics data produced by the international Pseudomonas aeruginosa consortium. Front. Microbiol. 6, 1036.

(37) Yan, S., and Wu, G. (2019) Can Biofilm Be Reversed Through Quorum Sensing in Pseudomonas aeruginosa? Front. Microbiol., DOI: $10.3389 /$ fmicb.2019.01582.

(38) Kitao, T., Lepine, F., Babloudi, S., Walte, F., Steinbacher, S., Maskos, K., Blaesse, M., Negri, M., Pucci, M., Zahler, B., Felici, A., and Rahme, L. G. (2018) Molecular Insights into Function and Competitive Inhibition of Pseudomonas aeruginosa Multiple Virulence Factor Regulator. $m$ Bio 9, No. e02158.

(39) Jackson, N., Czaplewski, L., and Piddock, L. J. V. (2018) Discovery and development of new antibacterial drugs: learning from experience? J. Antimicrob. Chemother. 73, 1452-1459.

(40) Maura, D., Drees, S. L., Bandyopadhaya, A., Kitao, T., Negri, M., Starkey, M., Lesic, B., Milot, S., Déziel, E., Zahler, R., Pucci, M., Felici, A., Fetzner, S., Lépine, F., and Rahme, L. G. (2017) Polypharmacology Approaches against the Pseudomonas aeruginosa MvfR Regulon and Their Application in Blocking Virulence and Antibiotic Tolerance. ACS Chem. Biol. 12, 1435-1443.

(41) Sherrard, L. J., Tunney, M. M., and Elborn, J. S. (2014) Antimicrobial resistance in the respiratory microbiota of people with cystic fibrosis. Lancet 384, 703-713.

(42) Ghosh, A., Jayaraman, N., and Chatterji, D. (2020) SmallMolecule Inhibition of Bacterial Biofilm. ACS Omega 5, 3108-3115.

(43) Wang, C., Zhao, W., Cao, B., Wang, Z., Zhou, Q., Lu, S., Lu, L., Zhan, M., and Hu, X. (2020) Biofilm-Responsive Polymeric Nanoparticles with Self-Adaptive Deep Penetration for In Vivo Photothermal Treatment of Implant Infection. Chem. Mater. 32, 7725-7738.

(44) Singh, N., Romero, M., Travanut, A., Monteiro, P. F., JordanaLluch, E., Hardie, K. R., Williams, P., Alexander, M. R., and Alexander, C. (2019) Dual bioresponsive antibiotic and quorum sensing inhibitor combination nanoparticles for treatment of Pseudomonas aeruginosa biofilms in vitro and ex vivo. Biomater. Sci. 7, 4099-4111.

(45) Cutuli, M. A., Petronio Petronio, G., Vergalito, F., Magnifico, I., Pietrangelo, L., Venditti, N., and Di Marco, R. (2019) Galleria mellonella as a consolidated in vivo model hosts: New developments in antibacterial strategies and novel drug testing. Virulence 10, 527541.

(46) D’Angelo, F., Baldelli, V., Halliday, N., Pantalone, P., Polticelli, F., Fiscarelli, E., Williams, P., Visca, P., Leoni, L., and Rampioni, G. (2018) Identification of FDA-Approved Drugs as Antivirulence Agents Targeting the pqs Quorum-Sensing System of Pseudomonas aeruginosa. Antimicrob. Agents Chemother. 62, No. e01296.

(47) Soukarieh, F., Vico Oton, E., Dubern, J. F., Gomes, J., Halliday, N., de Pilar Crespo, M., Ramirez-Prada, J., Insuasty, B., Abonia, R., Quiroga, J., Heeb, S., Williams, P., Stocks, M. J., and Camara, M. (2018) In Silico and in Vitro-Guided Identification of Inhibitors of Alkylquinolone-Dependent Quorum Sensing in Pseudomonas aeruginosa. Molecules 23, 257.

(48) Rahme, L. G., Stevens, E. J., Wolfort, S. F., Shao, J., Tompkins, R. G., and Ausubel, F. M. (1995) Common virulence factors for bacterial pathogenicity in plants and animals. Science 268, 1899-902.

(49) Winstanley, C., Langille, M. G. I., Fothergill, J. L., KukavicaIbrulj, I., Paradis-Bleau, C., Sanschagrin, F., Thomson, N. R., Winsor, G. L., Quail, M. A., Lennard, N., Bignell, A., Clarke, L., Seeger, K., Saunders, D., Harris, D., Parkhill, J., Hancock, R. E. W., Brinkman, F. S. L., and Levesque, R. C. (2008) Newly introduced genomic prophage islands are critical determinants of in vivo competitiveness in the Liverpool Epidemic Strain of Pseudomonas aeruginosa. Genome Res. 19, 12-23.

(50) Diggle, S. P., Matthijs, S., Wright, V. J., Fletcher, M. P., Chhabra, S. R., Lamont, I. L., Kong, X., Hider, R. C., Cornelis, P., Camara, M., and Williams, P. (2007) The Pseudomonas aeruginosa 4quinolone signal molecules $\mathrm{HHQ}$ and $\mathrm{PQS}$ play multifunctional roles in quorum sensing and iron entrapment. Chem. Biol. 14, 87-96.

(51) Popat, R., Crusz, S. A., Messina, M., Williams, P., West, S. A., and Diggle, S. P. (2012) Quorum-sensing and cheating in bacterial biofilms. Proc. R. Soc. London, Ser. B 279, 4765-71.

(52) Fletcher, M. P., Diggle, S. P., Camara, M., and Williams, P. (2007) Biosensor-based assays for PQS, HHQ and related 2-alkyl-4quinolone quorum sensing signal molecules. Nat. Protoc. 2, 1254-62.

(53) Essar, D. W., Eberly, L., Hadero, A., and Crawford, I. P. (1990) Identification and characterization of genes for a second anthranilate synthase in Pseudomonas aeruginosa: interchangeability of the two anthranilate synthases and evolutionary implications. J. Bacteriol. 172, 884-900.

(54) Heydorn, A., Nielsen, A. T., Hentzer, M., Sternberg, C., Givskov, M., Ersbøll, B. K., and Molin, S. (2000) Quantification of biofilm structures by the novel computer program COMSTAT. Microbiology (London, U. K.) 146 (10), 2395-2407.

(55) O'Brien, J., Wilson, I., Orton, T., and Pognan, F. (2000) Investigation of the Alamar Blue (resazurin) fluorescent dye for the assessment of mammalian cell cytotoxicity. Eur. J. Biochem. 267, $5421-6$. 